\title{
Ecosystem limits to food web fluxes and fisheries yields in the North Sea simulated with an end-to-end food web model
}

\author{
Michael R. Heath ${ }^{1, *}$ \\ ${ }^{1}$ University of Strathclyde, Marine Population Modelling Group, Department of Mathematics and Statistics, \\ Livingstone Tower, Glasgow G1 1XP, UK \\ *: Corresponding author : M. R. Heath, email address : $\underline{\text { m.heath@strath.ac.uk }}$
}

\begin{abstract}
:
Equilibrium yields from an exploited fish stock represent the surplus production remaining after accounting for losses due to predation. However, most estimates of maximum sustainable yield, upon which fisheries management targets are partly based, assume that productivity and predation rates are constant in time or at least stationary. This means that there is no recognition of the potential for interaction between different fishing sectors. Here, an end-to-end ecosystem model is developed to explore the possible scale and mechanisms of interactions between pelagic and demersal fishing in the North Sea. The model simulates fluxes of nitrogen between detritus, inorganic nutrient and guilds of taxa spanning phytoplankton to mammals. The structure strikes a balance between graininess in space, taxonomy and demography, and the need to constrain the parameter-count sufficiently to enable automatic parameter optimization. Simulated annealing is used to locate the maximum likelihood parameter set, given the model structure and a suite of observations of annual rates of production and fluxes between guilds. Simulations of the impact of fishery harvesting rates showed that equilibrium yields of pelagic and demersal fish were strongly interrelated due to a variety of topdown and bottom-up food web interactions. The results clearly show that management goals based on simultaneously achieving maximum sustainable biomass yields from all commercial fish stocks is simply unattainable. Trade-offs between, for example, pelagic and demersal fishery sectors and other properties of the ecosystem have to be considered in devising an overall harvesting strategy.
\end{abstract}

\section{Highlights}

Parameter optimization of an end-to-end food web model achieved by simulate annealing. Modeled yields of pelagic and demersal fish are strongly inter-dependent. Modeled impacts of fishing infiltrate the entire food web. The end-to-end model could be used to set the ecosystem context for individual species fishery targets. 


\section{Introduction}

The main preoccupation of fisheries management has been species-by-species conservation of exploitable stocks. However, there is growing awareness that sustainable harvesting rates of individual species may not be independent of one another due to predator-prey links in the ecosystem (e.g. Mueter and Megrey, 2006). In addition, there are demands to take account of the impacts of fishing on the food web as a whole (Hunsiker er al., 2011; Gaichas et al., 2010), as part of the process of setting harvesting targets. Hence, the scientific advice to fisheries management, which has hitherto relied mainly on single species population models, is increasingly required to incorporate information from models which include predator-prey interactions between fish species, and between fish and the other living components of the ecosystem (Hollowed et al., 2000).

Evidence of relationships between ecosystem structure and fisheries yield revealed by statistical analyses of marine data sets are a sound basis for developing hypotheses about how the impacts of fishing may infiltrate the ecosystem (e.g. Frank et al., 2007). However, any statistical relationships that emerge cannot be reliably used for prediction or strategic analysis due to the inherent non-linearity in the underlying responses and uncertainty as to which changes represent cause and effect.

The requirement is for dynamic models that capture both the bottom-up and topdown essence of how the ecosystem responds to fishing, climate and nutrient inputs 
(Murawski, 2000; Pitcher and Cochrane, 2002; Rose et al., 2010). There are numerous fisheries orientated model descriptions which wholly or partially address this problem, differing widely in approach, scope, and spatial and taxonomic resolution (see reviews by Plagányi, 2007; Fulton, 2009). The consequences for overall model performance of investing complexity in different aspects of the models (spatial, biogeochemical, trophic, demographic) have been extensively analysed (Fulton et al., 2003a,b, 2004a,b). Whilst there is not likely to be a single modelling solution to fit all situations and questions being asked, a clear outcome is that lack of parameter constraint is an overwhelming issue, and that this will tend to be accentuated with model articulation (Fulton et al., 2003a).

The approach adopted in this paper was to strategically sacrifice complexity in order to minimize the parameter count and enable a statistical quantification of the maximum likelihood parameter combination for a given ecosystem. The aim was to accomplish this whilst retaining a focus on fisheries issues, a representation of nutrient dynamics, and inclusion of the full range of trophic levels in the system. To achieve this, the biology of the entire ecosystem was represented by the bulk nutrient mass of a relatively small set of guilds or functional groups of taxa with weightspecific uptake rates defined by traditional functional responses (see also Fennel, 2010). Guild mass-based modelling approaches have a long history in marine science (Riley et al., 1949; Steele, 1958, 1974; Evans and Parslow, 1985; Jones and Henderson, 1987) but have previously had little impact on fisheries management systems due to the lack of representation of species demography. But, with the rise of legislation focused on ecosystem structure and function which relies on descriptors of the state of the system expressed in terms of trophic levels and functional groups (Rogers et al., 2010), there is clear scope for a revival of guild mass-based models which can be feasibly implemented in automatic optimization and probabilistic simulation schemes involving intensive replication of runs. The model described here is implemented to represent the North Sea, initially to answer the question "what is the combined impact of harvesting rates by pelagic and demersal fishery sectors on the composition and magnitude of annual landings, and the patterns of nutrient fluxes through the food web?"

\section{Model description}

The basic principles of the model originate from representations of nutrientphytoplankton-zooplankton guild-mass dynamics in coastal fjordic ecosystems (Ross et al., 1994). Fauna and flora of the model food web were represented by coarsely resolved guilds rather than individual species, and the network of guilds was similar to that described by Steele et al. (2007), Steele (2008) and Collie et al. (2009) to represent the Georges Bank ecosystem. The main differences between the network used here to represent the North Sea and that for the Georges Bank, were as follows:

- The benthic food web in the Georges Bank was represented by four guilds, whilst only two were resolved in the North Sea version.

- Fish in the Georges Bank web were resolved to three guilds plus a single juvenile compartment. Only two fish guilds were represented in the North Sea, but each had demographic structure represented by an egg/larval and an adult stage.

- Top predators were not represented in the Georges Bank web, whilst a single guild was included to represent all top predator taxa in the North Sea. 
The model simulated fluxes of a single nutrient element (nitrogen), between bulk mass state variables representing classes of detritus, dissolved nutrient, phytoplankton, benthos, zooplankton, fish, and top-predators. The state variables were further resolved to represent two depth layers in the water column, and a seabed sediment layer (Fig. 1). Rates of exchange between the mass compartments were described by a set of ordinary differential equations. Key features of the model were:

- External sources of nitrogen were from phytoplankton, detritus, nitrate and ammonia advected into the model domain by ocean currents, atmospheric deposition and river inputs of nitrate and ammonia.

- Exports of nitrogen from the model (sinks) were phytoplankton, detritus, nitrate and ammonia advected out of the model domain, nitrogen gas produced by denitrification, and fishery landings.

- Phytoplankton, detritus, nitrate and ammonia in the water column were subject to vertical exchange between depth layers (by sinking of particulate material and mixing). Detritus, ammonia and nitrate were subject to vertical exchange between the water column and sediment.

- Uptake of dissolved ammonia and nitrate by phytoplankton was confined to the surface layer and modeled according to a Michaelis-Menten function scaled by the depth averaged daily irradiance. Maximum uptake rate was temperature dependent according to a $\mathrm{Q}_{10}$ function, but the half-saturation coefficient was temperature independent.

- A constant proportion of phytoplankton per day was converted to detritus.

- Uptake of prey by all classes of predators was described by Michaelis-Menten functions with prey and temperature dependent maximum uptake rates. The halfsaturation coefficient was independent of both temperature and prey.

- Fixed proportions of food ingested by predators were assimilated, excreted to ammonia, and defaecated to detritus.

- Predators excreted a temperature dependent proportion of their body mass per day to ammonia, according to a $\mathrm{Q}_{10}$ function.

- Predators were subjected to a density dependent mortality rate, which created a flux to corpses.

- A proportion of corpse mass was converted to detritus per day, and similarly detritus to ammonia, ammonia to nitrate, and nitrate to nitrogen gas (denitrification). The proportions were temperature dependent according to a $\mathrm{Q}_{10}$ function.

- Fish were resolved into two demographic stages - larvae (including eggs), and adults. Adults shed a fixed proportion of their mass per day to larvae during prescribed time intervals each year. A fixed proportion of larvae were promoted to adults per day during a different prescribed interval.

- Adult fish and benthos categories were subject to harvesting which removed a proportion of their mass per day as catch. A fraction of the catch was returned to the food web as fishery discards, the remainder was regarded as landings which were a sink (Fig. 2).

- Benthos categories additionally suffered a by-catch mortality which was a fixed fraction of the demersal fish harvesting rate. This by-catch was passed directly to fishery discards (Fig. 2).

- The proportion of catch discarded was constant for pelagic fish and benthos, but scaled with adult abundance for demersal fish, to caricature the shift in fish size 
distribution towards smaller individuals with declining abundance in demersal fish communities (Greenstreet et al., 2010).

A full technical description of the model and parameters is given in the Supplementary Material. The model was implemented in the R statistical environment version 2.11.1 (R Development Core Team 2005), and used the lsoda routine in the package odesolve to solve the differential equations and output values of the state variables and a fluxes at daily time intervals.

\subsection{North Sea model setup and driving data}

The geographical setting of the model (Fig. 3) was defined by a combination of static and time-dependent physical and chemical parameters, and fishery harvesting and discarding rates. Static parameters were the water column and sediment layer thicknesses, sediment-water exchange rates and sediment porosity averaged over the North Sea (Table 1).

Time-dependent driving parameters were irradiance, temperature, vertical exchange rates, horizontal volume and material exchange rates across the open boundaries of each layer, and external inputs of water and material from rivers and atmospheric deposition. These parameters vary on a wide range of time scales, but were presented to the model as sets of monthly values over a climatological year to represent average conditions during the period 1970-1999. This period was chosen because demersal fishing mortality rates, which probably represent the major fishing pressure on the ecosystem, increased from 1970 to a peak in 1987 and then declined back to $\sim 1970$ levels by 2000 (Greenstreet et al., 2010), so that the trend over the entire era was negligible. Pelagic, demersal and benthic invertebrate fishery harvesting and discarding rates over this period were set as climatological annual averages derived from a combination of assessment and survey data.

The time dependent drivers were assembled relatively straightforwardly from raw data or published data syntheses (Tables 2, 3). Estimating monthly average vertical attenuation coefficients for surface irradiance required some intermediate steps involving data on suspended sediment concentrations (Table 4).

The derivation of biomass harvesting and fishery discard rates for fish and benthos guilds was more complicated than for the physical and chemical data. The procedure required integration of data from fish stock assessments, trawl surveys, international landings, and fishery observer data (Table 5 and Appendix 1).

\subsection{Summarizing the state of the ecosystem}

The mean state of the North Sea ecosystem during the period over which the driving data were compiled (1970-1999), was summarized by four types of derivatives from observed data, which could also be calculated from the model outputs. The first type comprised a set of 12 annually integrated gross production or exports of state variables in the model. These extended from denitrification and new and total annual primary production (Table 6) at the base of the food web, to the production rates of birds and mammals at the top, and fishery landings. For heterotrophic guilds, gross production was given by the product of total prey nutrient uptake and assimilation efficiency. The second type of measure comprised a set of 8 annually integrated predation fluxes between the guilds. The third type of summary measure comprised a 
set of 10 annual production:biomass ratios of the various guilds (annual gross production / annual mean biomass).

Annual production and flux estimates were summarized by the mean and standard deviation of published values for individual years during the 1970-1999 period (Table 7). Where only incomplete time series were available, standard deviations were conservatively estimated to be $50 \%$ of the observed value. Production:biomass ratios were summarized as the mean and sd of estimates available for individual taxa assigned to each guild (Table 7).

The fourth type of summary measure was a set of observed monthly average concentrations $\left(\mathrm{mMN} . \mathrm{m}^{-3}\right)$ for nutrient, phytoplankton and zooplankton categories in the model. were derived from a combination of records held at the ICES Environmental Data Centre and the Continuous Plankton Recorder (CPR) survey data center at the Sir Alister Hardy Foundation for Ocean Science (SAHFOS). Nutrient and chlorophyll observations collected between 1970 and 2000 were first averaged over three sub-areas of the North Sea (representing seasonally stratified, frontal and well mixed regions; Heath and Beare 2008) and depth layers by month and year. For each month, the median, and quartiles of the monthly values were then calculated. Sub-area medians and quartiles for each layer were combined to derive North Sea wide values by volumetric weighted averaging. Phytoplankton nitrogen mass was derived from chlorophyll concentration assuming a C:chlorophyll weight ratio of 40, and a Redfield molar ratio of C:N. CPR zooplankton species numbers were converted to biomass and grouped into omnivorous and carnivorous categories (Broekhuizen et al., 1995; Heath, 2005) for each ICES sub-area, year and month. Then, the median and quartiles of the monthly values for the whole North Sea were calculated. Zooplankton nitrogen mass was estimated from biomass assuming a water content of $83 \%, \mathrm{C}$ :dry weight ratio of $70 \%$ and a Redfield molar ratio of C:N.

\subsection{Model parameter optimization}

The model parameters varied in the degree to which they could be reasonably estimated independently at the level of spatial and taxonomic aggregation in the model. A quantitative fitting method was required to fit the parameters which were most constrained by the observations, subject to the values assigned to the remaining unconstrained parameters. The approach was to run the model to a stationary state with an annually repeating cycle of monthly driving data representing the mean values over the 30 year period 1970-1999 in the North Sea. The mean state of the real-world system over this same period was then assumed to be equivalent to the stationary model, and the model was optimized by seeking the vector of a subset of parameter values required to produce the best overall fit.

A two-stage optimization process was adopted. The first stage involved rough hand-fitting. Starting from an informed guess for all of the parameters, values were adjusted one at a time within sensible ranges whilst observing the pattern of changes in the model outputs, to achieve persistence of all model components at approximately the correct abundances. The model was then embedded in a simulated annealing scheme using the Metropolis-Hastings iterative algorithm (Cerny, 1985; Kilpatrick et al., 1983; Bertsimas and Tsitsiklis, 1993; Matear, 1995; Kavanagh et al., 2004). The algorithm automated the acceptance or rejection of proposed new randomly generated sets of selected parameters using the hand-fit vector of parameters as initial conditions. Full details of the simulated annealing scheme are given in Appendix 2. 
The objective of the scheme was to maximize the likelihood of the observed data given a vector of parameter values. For $1<i \leq I$ target indices $(i)$ derived from observed data, each of standard deviation $\sigma_{i}$, an error function $\chi_{\theta}{ }^{2}$ was calculated for a given vector of parameters $\theta$, which described the discrepancy between the same indices derived from the model results and the observed data:

$\chi_{\theta}{ }^{2}=\frac{\sum_{i=1}^{i=I} \frac{\left(\text { observed }_{i}-\bmod e l_{\theta, i}\right)^{2}}{2 \sigma_{i}{ }^{2}}}{I}$

The likelihood of the observations given the parameter values was then estimated as:

$\mathrm{P}($ observations $\mid \theta)=\exp \left(-\chi_{\theta}{ }^{2}\right)$

The target data in the simulated annealing scheme were the real-world means and standard deviations of annual productions, fluxes and production:biomass ratios of the model guilds. As an independent test, the simulated maximum likelihood time series of monthly averaged concentrations of nutrient and chlorophyll concentrations, and biomasses of zooplankton, were also required to lie within the ranges of real-world monthly average values. Also, these data were not included in the simulated annealing scheme because small phase differences between the time-dependent observations and simulation results caused large deviations in the quantitative error function, but did not necessarily reflect biologically important mis-fits of the model, (Wood, 2010).

Seventy two parameters distributed across 5 classes according to their role in the model (preference, maximum uptake, half-saturation constants, biogeochemical, and density dependent mortality rates) were considered as potentially available for inclusion in the simulated annealing process. 50 parameters were excluded from the process and set internally on the grounds of being reasonably defined from external knowledge. These were the light saturation intensity for autotrophic uptake, $\mathrm{Q}_{10}$ values, assimilation and background metabolic coefficients, fish spawning and recruitment dates, and fish fecundity rates (Supporting Material Tables S8 and S9).

\subsection{Scenario simulations}

The model was first run for 80 repeating annual cycles of the 1970-1999 climatological driving data and harvesting rates, with the maximum likelihood parameter vector $\left(\theta_{\mathrm{ml}}\right)$. The saved final state of this model run was used for initializing subsequent runs. Annually repeating 80 -year runs of the model were then carried out to explore the 2-dimensional harvesting rate space defined by pelagic harvesting $=0$, $0.5,1.0,1.5,2.0,2.5,3.0$-times the 1970-1999 rate, and demersal harvesting $=0,0.5$, $1.0,1.5,2.0,2.5,3.0$-times the $1970-1999$ rate $(7 \times 7=49$ combinations). The 1970 1999 climatological ocean transport, external nutrient inputs and shellfish harvesting rates were applied in every case. The results were summarized by annual averaged or integrated indices calculated over the final year of each run, including the annual landings and discards, annual production rates and mean biomasses of all the living categories in the model, annual fluxes of nutrient, and the annual diet compositions of pelagic and demersal fish.

\section{Results}




\subsection{Climatological (1970-1999) driving conditions}

The climatological annual cycles of monthly averaged physical and chemical driving conditions for the model (Figs. 4, 5, 6) showed summer minimia in suspended particulate matter, vertical mixing, ocean advection, river inflow, and boundary and river nitrate concentrations, in addition to the expected seasonality in irradiance and temperature. Climatological fishery harvest ratios (Table 8) were similar for pelagic and demersal fish, and two orders of magnitude lower for the benthos guilds. Discarding rates at 1970-1999 average guild biomass levels were 3-times higher for demersal fish than for the other exploited guilds.

\subsection{Maximum likelihood vector of parameters}

The likelihood of the observed ecosystem indices given the initial hand-fit parameter vector was 0.2 . Sequences of the likelihood of observations given accepted parameter vectors from the simulated annealing runs (example shown in Fig. 7), typically attained a maximum value within 600-800 iterations and the likelihood was improved to 0.42 with all 72 free parameters being varied at each iteration. However, the final best-fit vector was acceptably independent of perturbations in the initial hand-fit vector, only if the cv of the perturbation was small $(<0.025)$. Hence, although the maximum likelihood vector produced a clear improvement in the overall fit of the model to the observations, the fit was not necessarily uniquely the best possible. The scheme was also not completely successful at recovered the maximum likelihood parameter vector when the fitted model results were substituted as target data and the vector was initially perturbed by Gaussian increments. The coefficients of variation between the initially perturbed and maximum likelihood parameter values, and between the recovered and maximum likelihood values at the end of the annealing process (>3000 iterations) showed that whilst most parameters had migrated back towards the maximum likelihood value, some had wandered further away. Experimenting with each of 5 classes of parameters separately (preference, maximum uptake, half-saturation constants, biogeochemical, and density dependent mortality rates) showed that the biogeochemical parameters were least constrained by the suite of observations, whilst the density dependent mortality rates and maximum uptake rates were most constrained (Fig. 8).

Deviations of individual parameters from the maximum likelihood value during the converged phase of an annealing run (iterations $=221$ with no new parameter vectors accepted) were significantly correlated $(p<0.05)$ with the resulting likelihood for around half of the parameters (39 out of 72). A chi-squared test showed that there as no significant tendency for any particular class of parameter (preference, uptake rate, half-saturation constant, density dependent mortality coefficient, or biogeochemical) to be correlated with the overall likelihood of the model. (Table 9). The implication was that the overall model was not markedly sensitive to any particular class of parameter, rather to the network of parameters as a whole.

As expected, maximum likelihood uptake rates declined in line with the typical body size and trophic level of individuals within each guild, from $2.8 \mathrm{~d}^{-1}$ for phytoplankton and suspension/deposit feeding benthos, (which included meiobenthos) to $0.015 \mathrm{~d}^{-1}$ for adult demersal fish. The exception was the bird/mammal guild which emerged with a maximum uptake rate between those for pelagic fish adults and carnivorous zooplankton (Supplementary Material Table S10). Maximum likelihood 
prey preference and biogeochemical parameters are given in the Supplementary Material (Tables S11 and S12).

Detailed comparison of the maximum likelihood stationary model solution with the target observed data showed that some aspects of the data were better explained by the model than others (Table 7). In particular, primary production, pelagic fish production, and demersal fish landings data were well explained, whilst the consumption of pelagic fish by other fish and by birds/mammals, and denitrification rates were least well explained. Comparison of the stationary annual cycle of monthly averaged nitrate, ammonia, phytoplankton chlorophyll and zooplankton concentrations in the model with the equivalent 1970-1999 observations (Fig. 9) showed that the model performed well at explaining surface layer dissolved nutrients and zooplankton concentrations, and less well at explaining deep layer nutrients and chlorophyll concentrations. The key point regarding the monthly averaged data was that the model was not in any sense fitted to these observations, so the qualitative fit represented an independent evaluation of the model performance. The maximum likelihood stationary annual cycles of all model state variables are shown in the Supplementary Material (Figs. S1-S5).

\subsection{Mass balance of the 1970-1999 stationary model ecosystem}

The mass of nitrogen in the system varied over the stationary annual cycle between 1125 and $1053 \mathrm{mMN} \cdot \mathrm{m}^{-2}$, with an annual import set by the driving conditions of 1697 $\mathrm{mMN} \cdot \mathrm{m}^{-2} \cdot \mathrm{y}^{-1}(90 \%$ dissolved inorganic nutrient (DIN) advected across the open boundaries and from rivers and the atmosphere, $10 \%$ particulate organic nitrogen (PON) advected across the open boundaries). The import was matched by an equal export comprising 94\% DIN by advection, 4\% PON by advection and fisheries landings, and $2 \%$ as nitrogen gas due to denitrification. The removal of nutrient from the system by fishery landings $\left(6.6 \mathrm{mMN} . \mathrm{m}^{-2} \cdot \mathrm{y}^{-1}\right)$ represented only a small fraction $(0.4 \%)$ of the annual export by advection and denitrification. Hence, at the macroscale the North Sea appeared to act as a net importer of PON at a rate of $105 \mathrm{mMN} . \mathrm{m}^{-}$ ${ }^{2} \cdot \mathrm{y}^{-1}$, and an equivalent net exporter of DIN and nitrogen gas (Fig. 10).

\subsubsection{Primary production}

The annual f-ratio (NIP/TAPP; Dugdale and Goering, 1967; Eppley and Peterson, 1979) was 0.67, and lower (0.46) if based on MMIP, i.e. MMIP/TAPP (Table 10). The total import of DIN to the system (advection + atmospheric deposition + river discharge $=1522 \mathrm{mMn} \cdot \mathrm{m}^{-2} \cdot \mathrm{y}^{-1}$ ) did not equate exactly to any of the new production measures but was similar in magnitude to the total annual primary production (TAPP $=1507 \mathrm{mMn} \cdot \mathrm{m}^{-2} \cdot \mathrm{y}^{-1}$, equivalent to $119 \mathrm{gC} \cdot \mathrm{m}^{-2} \cdot \mathrm{y}^{-1}$ )

\subsubsection{Nutrient recycling processes}

The particulate flux from the water column to the sediment was $1514 \mathrm{mMN} \cdot \mathrm{m}^{-2} \cdot \mathrm{y}^{-1}$, and $84 \%$ of total annual detritus mineralization $\left(149 \mathrm{mMn} \cdot \mathrm{m}^{-2} \cdot \mathrm{y}^{-1}\right)$ took place in the sediment. Fishery discards of fish and benthos which were not consumed by other fish and birds/mammals represented only $0.1 \%$ of the total annual particulate flux to the sediment. Most of the annual production of ammonia (1931 mMN.m $\left.{ }^{-2} \cdot \mathrm{y}^{-1}\right)$ occurred in the sediment (77\% due to sediment-water flux, 33\% due to ammonia production in the water column by bacterial and heterotrophic metabolism). In contrast, almost all 
$(>99 \%)$ of the annual nitrification $\left(1275 \mathrm{mMN} \cdot \mathrm{m}^{-2} \cdot \mathrm{y}^{-1}\right)$ occurred in the water column, and $<1 \%$ in the sediment. In fact, the sediment was a net consumer of nitrate, drawing $25 \mathrm{mMN} \cdot \mathrm{m}^{-2} \cdot \mathrm{y}^{-1}$ of nitrate out of the water column. The dominance of annual sediment-water nutrient fluxes by ammonia is borne out by experimental observations (Lohse et al. 1996, Law and Owens 1990). Denitrification (37 mMN.m ${ }^{-2} \cdot \mathrm{y}^{-1}$ ) was concentrated in the sediment $(75 \%)$. Total annual denitrification represented $23 \%$ annual river and atmospheric inputs, which is of similar magnitude to that estimated by other investigators (Law and Owens, 1990).

\subsubsection{Heterotrophic food web fluxes}

Total annual higher trophic level production (all zooplankton, benthos, fish, and birds/mammals combined) amounted to $809 \mathrm{mMN} \cdot \mathrm{m}^{-2} \cdot \mathrm{y}^{-1}$ (equivalent to $64 \mathrm{gC} \cdot \mathrm{m}^{-2} \cdot \mathrm{y}^{-}$ ${ }^{1}$ ), which represented $116 \%$ of MMIP, and 54\% of TAPP. Total fish production (larval and adult pelagic and demersal; $41 \mathrm{mMN} \cdot \mathrm{m}^{-2} \cdot \mathrm{y}^{-1}, 3.3 \mathrm{gC} \cdot \mathrm{m}^{-2} \cdot \mathrm{y}^{-1}$ ) represented $2.7 \%$ of TAPP. The fishery landings of pelagic, demersal and shellfish represented $0.44 \%$ of TAPP, in line with ratios derived by a variety of means from observational data (Nixon 1988; Chassot et al., 2007). Top predator (bird/mammal) production was $2.3 \times 10^{-3} \mathrm{mMN} \cdot \mathrm{m}^{-2} \cdot \mathrm{y}^{-1}, 2.3 \times 10^{-4} \mathrm{gC} \cdot \mathrm{m}^{-2} \cdot \mathrm{y}^{-1}$, equivalent to $0.00016 \%$ of TAPP.

Considering the pelagic food web alone (Fig. 11), total zooplankton production (herbivores and carnivores combined; $280 \mathrm{mMN} \cdot \mathrm{m}^{-2} \cdot \mathrm{y}^{-1}, 22 \mathrm{gC} \cdot \mathrm{m}^{-2} \cdot \mathrm{y}^{-1}$ ) represented $19 \%$ of TAPP. The flux of nitrogen from herbivorous zooplankton up the food web was mainly (51\%) directed to pelagic fish (approximately 50:50 between larvae and adults), $41 \%$ to carnivorous zooplankton and $7 \%$ to demersal fish larvae. However, adult pelagic fish were the major predators on carnivorous zooplankton, so a large part of the flux from herbivorous to carnivorous zooplankton contributed indirectly to pelagic fish production. Carnivorous zooplankton were also significant predators on fish larvae, and the consumption flux from larvae to carnivorous zooplankton approximately matched the flux from carnivorous zooplankton to adult fish, for both pelagic and demersal fish. Predation on pelagic fish (larvae and adults combined) by demersal fish approximately matched that due to carnivorous zooplankton. Predation by birds and mammals represented only a small fraction of the total mortality on fish, but the majority of the diet of birds/mammals was pelagic fish.

Demersal fish acted as a link between the pelagic and benthos food webs. Adults and larvae combined obtained approximately equal proportions of their diet from the pelagic web (zooplankton and pelagic fish, $16.9 \mathrm{mMN} \cdot \mathrm{m}^{-2} \cdot \mathrm{y}^{-1}$ ), and from the benthos food web $\left(19.4 \mathrm{mMN} \cdot \mathrm{m}^{-2} \cdot \mathrm{y}^{-1}\right)$. The other main connection between the pelagic and demersal webs was through fishery discards and corpses resulting from density dependent mortality of pelagic web components. Together these contributed $0.043 \mathrm{mMN} \cdot \mathrm{m}^{-2} \cdot \mathrm{y}^{-1}$ back into the pelagic web, and $4.7 \mathrm{mMN} \cdot \mathrm{m}^{-2} \cdot \mathrm{y}^{-1}$ to the benthos web.

Benthos production (suspension/deposit feeders and carnivorous/scavenging; $488 \mathrm{mMN} \cdot \mathrm{m}^{-2} \cdot \mathrm{y}^{-1}, 39 \mathrm{gC} \cdot \mathrm{m}^{-2} \cdot \mathrm{y}^{-1}$ ) represented 32\% of TAPP (Fig. 12). At 1970-1999 shellfish harvesting rates only a small proportion of this was removed as landings (0.07 mMN.m ${ }^{-2} . \mathrm{y}^{-1}, 0.01 \%$ of production). Approximately $10 \%$ of the diet of carnivorous/scavenging benthos comprised corpses originating from fishery disards and density dependent mortality in the pelagic and benthic food webs. Approximately $66 \%$ of the flux due to predation on suspension/deposit feeding benthos was due to carnivorous benthos, and the remainder to demersal fish adults. 


\subsection{Simulated fishing scenarios}

\subsubsection{Fisheries yield}

Varying either pelagic or demersal harvesting rates whilst keeping the other fixed, produced characteristic responses in abundance, production, landings and discards of the targeted fish guilds. Production and biomass declined from a maximum value in the un-exploited situation towards effective extinction as the harvesting rate was increased. Over the same range, landings and discards varied from zero in the unexploited situation, through a maximum and back towards zero as the resource approached extinction (Fig. 13, 14). The maximum of the landings response was referred to as the maximum sustainable yield (MSY) from the functional group, and

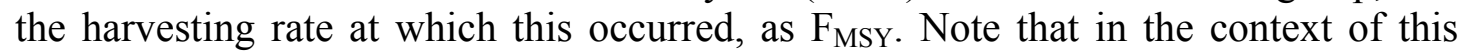
study the maximum yield was defined in terms of landings, not catch, since only the landings were extracted from the ecosystem. $\mathrm{F}_{\mathrm{MSY}}$ for the demersal guild would be different if defined in terms of catch as opposed to landings because the discarding rate scaled with adult abundance. Single-species analyses usually regard yield as defined by catch since this is the removal rate from the population.

In addition to the above patterns, which were entirely consistent with responses observed in single species stock models, the ecosystem model predicted strong interactions between the pelagic and demersal fish guilds (Fig. 13, 14). Pelagic fish MSY and $\mathrm{F}_{\mathrm{MSY}}$ both increased with demersal harvesting rate, i.e. decreasing demersal fish abundance. Similarly, demersal fish MSY and F $_{\text {MSY }}$ increased with pelagic fish harvesting rate (Fig. 15). The former was, on face value, a reasonably predictable response of the pelagic fish guild to reduced abundance of its main predator (demersal fish). However, the response of demersal fish MSY required some explanation since the logical consequence of depressing the abundance of one of the main prey of demersal fish would be a reduction in the yield, not an increase.

The annual production:biomass ratio of adult demersal fish was directly related to the proportion of fish in the diet (Fig. 16), which decreased with pelagic harvesting. Hence, the enhancing effect of increased pelagic fishing on demersal MSY could not be explained by factors affecting the productivity of the adults, and must have been due to effects on the larvae. The annual productivity of larval demersal fish was estimated by the ratio of recruitment to egg production. Recruitment was the annual promotion flux of larvae to adults, whilst egg production was the annual flux of mass from adults to larvae to represent spawning. The ratio was dictated by the balance between assimilation of food, and mortality due to predation and density dependence, and increased with pelagic fish harvesting (Fig. 17). The sole food of fish larvae in the model was herbivorous zooplankton, and the predators were adult fish and carnivorous zooplankton. Suppression of adult pelagic fish abundance by fishing released both herbivorous and carnivorous zooplankton from predation and caused an increase in their production (Fig. 18). This created conflicting pressures on demersal fish larvae. Decreasing predation from adult pelagic fish was offset by increasing predation from carnivorous zooplankton, whilst increased herbivorous zooplankton production enhanced food uptake. Overall, the variation in annual food assimilation rate (larval production per unit egg production) within the harvesting rate space was greater than the variation in overall predation. Hence, the productivity of demersal fish larvae was strongly enhanced by the suppression of pelagic fish through harvesting, and this was the main factor affecting the response of MSY (Fig. 19). However, the key point is that this was not primarily due to relaxation of direct 
predation on larvae by pelagic fish. The main mechanism was indirect through the food web due to the release of herbivorous zooplankton from predation and stimulation of food uptake by demersal larvae.

\subsubsection{Effects on the benthic food web}

The effects of fishing were not confined to fish and zooplankton, but permeated the entire food web, even so far as to affect winter nutrient concentrations. However, the impact of fishing was attenuated with trophic distance down the food web towards primary production and nutrients, and amplified up the food web to birds/mammals (Table 11).

One obvious impact on the benthos food web was a change in landings and discards of shellfish in response to variations in both pelagic and demersal fish harvesting, despite constant harvesting rates applied to benthos guilds by the shellfish fishery (Fig. 20). Shellfish landings and discards increased with demersal harvesting and decreased with pelagic harvesting. The increase in discards with demersal harvesting was partly due to the by-catch rate of benthos in the demersal fishery, but the landings were entirely due to the targeted shellfish fishery. The indication was that production in the benthos food web was enhanced by the depletion of demersal fish abundance, and suppressed by the depletion of pelagic fish abundance. The former was, on face value, a predictable response to the release of predation pressure on benthos by demersal fish, but the latter required further investigation.

The main predator on suspension/deposit feeding benthos was the carnivorous/scavenge feeding benthos guild but this varied in abundance considerably less than demersal fish over the harvesting rate space. Hence, the overall mortality rate of suspension/deposit feeding benthos (annual predation loss/annual average biomass) was directly related to demersal fish abundance (Fig. 21). Production per unit biomass of suspension/deposit feeding benthos varied less than predation mortality, hence the annual production of the guild was highest when demersal fish abundance was at a minimum (maximum demersal harvesting, zero pelagic harvesting).

The situation was rather different for the carnivorous/scavenge feeding guild. Here, the predation mortality rate was also directly related to demersal fish abundance, but production per unit biomass showed a complex bi-modal response to the harvesting rates with a main peak at high pelagic, low demersal harvesting, and.a second peak at high demersal low pelagic harvesting (Fig. 22). This pattern arose because corpses deriving from discards and density dependent mortality made up the major part of the diet of the carnivorous/scavenge feeding guild. Corpse production due to density dependent mortality was greatest at the extremities of the harvesting rate space, where some guilds were present in excess due to the near-extinction of others.

\subsubsection{Effects on birds/mammals}

The overall food consumption by birds/mammals in the model was most closely related to pelagic fish abundance, as the major component of the diet. Bird/mammal annual production was strongly affected by pelagic harvesting rate (Fig. 23). The maximum contribution by weight of discards to the diet was $1.7 \%$, which was attained at maximum pelagic harvesting rate and $\mathrm{F}_{\mathrm{MSY}}$ for demersal fish. 


\section{Discussion}

\subsection{Fisheries yields}

Equilibrium production and biomass of pelagic fish declined, and yield peaked, in response to pelagic harvesting as would be expected in any biomass production or population model (Fig. 13). Demersal fish production, biomass and yield varied similarly in response to demersal harvesting (Fig. 14). However, these simulated responses were strongly sensitive to the state of the food web surrounding each fish guild. In particular, the equilibrium production, biomass and yield of demersal fish were inversely related to the abundance of pelagic fish. The maximum demersal fish yield from the ecosystem, was achieved when pelagic fish were harvested to near extinction. The mechanisms in the model which led to this effect were predation on the larval guilds by adults, and indirect interactions through the food web involving zooplankton. Clearly, an ecosystem in which one of the fish guilds has been harvested to extinction represents an ecologically dysfunctional state, which can be ruled out as a management strategy for maximizing yields from the remaining guild. The result illustrates why, from a dynamic perspective, maximum equilibrium yield is not a fixed property of a species or guild, but is conditional on other harvesting activities and natural changes which affect the food web surrounding the species or guild in question (Mueter and Megrey, 2006).

The conclusions have direct consequences for the way in which objectives for fisheries management are framed, which depend largely on the concept of maximum sustainable yields (Sparholt and Cook, 2010). Historically, MSY has been calculated on a species-by-species basis for a given management area, assuming timeindependent stock-recruitment patterns and natural (non-fishing) mortality rates (Shelton and Mangel, 2011). Advice on Total Allowable Catches (TAC's) has then been delivered, also on a species-by-species basis, with the aim of managing each stock relative to its MSY which is assumed to be fixed. The potential for predatorprey connections between fish species to influence MSY estimates has always been recognized (Tyrrell et al., 2011) but the implementation of models which take sufficient account of all the possible interactions has been problematic (Hollowed et al., 2000).

A variety of multi-species fish models capable of exploring the community consequences of harvesting strategies for individual species are available in the literature (see review by Plagányi, 2007; Gaichas et al., 2010; Hall et al., 2006). For the North Sea, Mackinson et al. (2009) used an EwE (Ecopath with Ecosim) model to explore the interactions between fisheries for cod, haddock and whiting. The conclusion was that it was not possible to simultaneously achieve yields of each of these species corresponding to the MSY's arising from single-species models. This conclusion arose principally from the direct predator-prey links between the three species in the EwE model (Mackinson and Daskalov, 2007), rather than through indirect food web interactions. In a similar vein, Speirs et al. (2010) simulated the population demography of a community of 9 fish and invertebrate species in the North Sea, embedded in size-spectrum representations of the surrounding ecosystem, and concluded that simultaneous maximum yields of cod and herring were unattainable due to predator-prey linkage. In this case the linkage was more complex since herring were shown to be both prey for adult cod and predators on cod eggs and larvae which were explicitly represented in the model. This result appeared to reinforce the empirical observations of Fauchald (2010), who noted that cod recruitment in the 
North Sea has been negatively related to herring biomass. It was argued that recent intensive harvesting of cod may have released herring from predation control, whilst during past times a large abundance of herring suppressed cod recruitment due to predation on eggs and larvae.

Both the Mackinson at al. (2009) and Speirs et al. (2010) approaches to investigating equilibrium multi-species fisheries yield have limitations with regard to indirect interactions between species through the food web. In the case of EwE, the representation of indirect food web interactions was potentially limited by the lack of representation of nutrient biogeochemistry and plankton dynamics. In the case of Speirs et al. (2010), the model was more advanced in explicitly representing the demography of species, but progression through the size classes was independent of food consumption which ruled out 'bottom-up' food web effects.

The model presented here does not resolve individual species, so the speciesspecific trade-offs indicated by Mackinson et al. (2009) and Speirs et al (2010) could not be explored in an ecosystem context. However, the generic properties which give rise to the species-specific MSY interactions were present at the guild level in the model, with the additional dimension of a fully integrated biogeochemical basis to set limits to production and yield. Hence, both top-down and bottom-up food web interactions were simultaneously possible. The results show that at every level of the web, both direct and indirect trophic interactions operated to determine equilibrium abundance and production and the responses to fisheries harvesting. So, for example, if the case of cod-herring interaction in the North Sea is set alongside the demersalpelagic fish guild interaction in the model presented here, then it is clear that pelagic fish predation on demersal eggs and larvae, as per Speirs et al. (2010), is not the only mechanism which can result in the empirical observation of Fauchald (2010). The indirect effect of pelagic fish predation on zooplankton, and the resulting impact on productivity of demersal fish larvae could also contribute to the dynamics. Interestingly, Fauchald (2010) refers to Calanus finmarchicus abundance in the North Sea as being an additive factor affecting cod recruitment in a statistical analysis (along with herring biomass), but predation effects on the abundance of $C$. finmarchicuis would likely be due to the community of predators rather than herring alone. In addition, $C$. finmarchicus is a relatively minor component of the diet of cod larvae in the North Sea, where Pseudocalanus sp. stages are more important (Heath and Lough, 2007), so the ecological basis for the statistical association between $C$. finmarchicus and cod recruitment in the North Sea is not completely clear.

\subsection{Model fitting}

The process of fitting ecosystem models to observations by parameter value selection is an important part of the task of establishing model credibility (Hilborn and Mangel, 1997), and for statistical inference regarding alternative models (de Valpine et al., 2002; Kinzey and Punt, 2009; Hartig et al. 2011). A variety of gradient-based and random walk optimization algorithms have been investigated for model fitting (e.g. Ito et al., 2010; Kuroda and Kishi, 2004; Matear, 1995), with simulated annealing being identified as an operational approach for ecosystem models of similar scope and complexity to that described here (Kavanagh et al., 2004).

Simulated annealing did not identify any parameter set which allowed the current model structure to fit the observations with probability 1 . The residual, unexplainable misfit presumably represented some combination of structure inadequacy in the model, and inaccuracy in the observations. Structural inadequacy is 
entirely to be expected. The degree of spatial aggregation, and the caricatures of processes, species and demography that were encapsulated in the simple functions describing guild uptake and losses were such that a perfect-fit parameter set would be highly unlikely. Confounded with this, the observations themselves were of variable accuracy and precision, since they too were aggregated from spatially distributed measurements of diverse origin. Estimates of imprecision in the observations were incorporated into the error function which measured the distance between the model results and the observations, but systematic inaccuracy in the observed values would also contribute to the unexplainable distance between the best-fit model and the observations. Finally, the equilibrium model solution with 1970-1999 averaged driving conditions was fitted to similarly time-averaged observations, assuming that these represented the equilibrium state of the ecosystem. However, we cannot be sure that this assumption is correct for all components of the system. In particular, the time to equilibration following a disturbance may be much longer than 30 years for the highest tropic levels, leading to an inbuilt misfit between the stationary model and observations. Nevertheless, the strategy of fitting the stationary model was a useful and practical starting point for the model development.

\subsection{Equilibrium fluxes in the 1970-1999 fitted model}

\subsubsection{Nutrient budgets}

Previous data analysis studies have been inconclusive as to whether the North Sea is a net source or sink for total nitrogen, and on the magnitudes of the gross fluxes. Overall, the simulations here suggested that the North Sea was a net exporter of nitrogen (DIN plus PON) across the northern boundary to the Atlantic of around 964 kt. $^{-1}$ (molar export per unit area x seas surface area / molecular weight), compared to

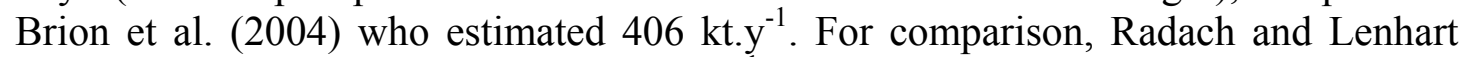
(1995) estimated a net export of $710 \mathrm{kt}^{-1} \mathrm{y}^{-1}$ from a spatial simulation model, whilst Hydes et al. (1999) estimated the North Sea to be a net sink of $1990 \mathrm{kt}^{-1}{ }^{-1}$.

Many of the discrepancies between the various budget estimates arise from differences in the assumed boundary concentrations, advective fluxes and atmospheric deposition rates. (Table 12). Regarding the inflow estimates, closer examination of the calculations presented by Brion et al. shows that their results were based on annual average concentrations of total nitrogen throughout the water column at the northern boundary of the North Sea, the Skagerrak and the English Channel, which were higher than the average of the monthly resolved data used to drive the model presented here (Brion et al., northern boundary $13.0 \mathrm{mMN} . \mathrm{m}^{-3}$, Skagerrak $11.7 \mathrm{mMN} . \mathrm{m}^{-3}$, southern boundary $8.9 \mathrm{mMN} . \mathrm{m}^{-3}$; this study, northern boundary $7.0 \mathrm{mMN} . \mathrm{m}^{-3}$, Skagerrak 6.2 mMN.m ${ }^{-3}$, southern boundary $6.1 \mathrm{mMN}^{-3} \mathrm{~m}^{-3}$ ) but their estimates of annual volume flux were lower. Across the northern boundary the values are relatively similar (Brion et al., 1.035 Sv averaged over 1976-1995; this study 1.537 Sv). However, across the Skagerrak boundary Brion et al. state that there is only an outflow from the North Sea of $0.054 \mathrm{~Sv}$, whilst analysis of the NORWECOM data shows an inflow of $0.823 \mathrm{~Sv}$. At the English Channel boundary the two studies were more in agreement (Brion et al. $0.042 \mathrm{~Sv}$, this study $0.076 \mathrm{~Sv}$ ). It is difficult to understand the basis for Brion et al.'s assumption that there is only an outflow from the North Sea across the Skagerrak boundary since this cannot be the case simply on mass balance grounds. In this study, integrated inflows and outflows along each of the boundary sections were obtained from the NORWECOM model. Summed over the North Sea, we would expect the 
sum of all ocean inflows plus river inputs (and rainfall if this were included in the NORWECOM model) to equal the sum of all outflows.

Regarding atmospheric deposition, Brion et al. relied on a combination of wet deposition monitoring data from OSPARCOM (1998b), and relatively crude estimates of dry deposition from van Boxtel et al. (1991). In this study, the more recent (2003) estimates of combined wet and dry deposition from the Co-operative Programme for Monitoring and Evaluation of the Long-range Transmission of Air pollutants in Europe (EMEP) were used, which should be more reliable. In addition, Brion et al. assumed a larger sea surface area $\left(700,000 \mathrm{~km}^{2}\right.$, compared to $\left.557,428 \mathrm{~km}^{2}\right)$.

The model results indicated that the ecosystem as a whole exported less particulate nitrogen than it imported, even taking into account fishery landings as an export. The particulate matter consumed by the system was exported in dissolved inorganic forms and nitrogen gas (65\% DIN). Hence, in an ecosystem metabolism sense, the model indicated that the North Sea was net-heterotrophic (Smith and Hollibaugh, 1993). The fundamental cause of the net-heterotrophic status was the retention of particulate matter in the system. The only forms of PON exported from the model were phytoplankton and suspended detritus, and fish landings. Converting the system to display net-autotrophic behaviour would presumably require phytoplankton to take up DIN over a greater proportion of the water column and/or at higher rates so as to reduce the concentrations of DIN in the water column and fix more of the available nitrogen as suspended PON. It is not clear that allowing import and export of other living components, e.g. zooplankton, would significantly affect the net metabolic status of the system, since their concentrations were very much lower than phytoplankton and detritus.

\subsubsection{Structure of the simulated ecosystem}

The major flows of nutrient through the model food web were fitted to the assembled target data set, so clearly the model results conformed with our understanding of production at various trophic levels of the system. Of more interest and diagnostic value were the emergent fluxes for which there were little or no established measurements. For example, the difference between the MMIP measure of new production and the annual uptake of nitrate, relative to total annual primary production $\left(\mathrm{MMIP} / \mathrm{TAPP}=0.46\right.$, Total $\mathrm{NO}_{3}$ uptake/TAPP $\left.=0.67\right)$ indicated the extent of within-year recycling activity in the system. In the open ocean we would expect these two ratios to be more similar since a high proportion of organic production is exported permanently from the photic zone to the deep ocean. The model clearly indicates that this is not the case in the shallow North Sea and that the over-turn of organic matter is much more rapid. Related to this, the simulation results implied that the majority of nutrient flux between the sediment and overlying water column was in the form of ammonia, not as nitrate, and that the bulk of nitrification occurred in the water column (Ward, 2005; Yool et al., 2007). Denitrification, which was concentrated in the sediment, effectively consumed the products of nitrification in the sediment and in fact, the model sediment was a small net consumer of nitrate from the water column.

The overall diet composition of adult demersal fish guild in the 1970-1999 fitted model contained $24 \%$ fish, which seems reasonable bearing in mind that the demersal guild includes all benthivourous fish, such as flatfish, as well as the more piscivorous species such as cod (Greenstreet et al., 1997). Even cod do not fully 
develop piscivory until around age 1-2, so on a population biomass basis the extent of piscivory appears less than on a per capita basis.

Savenging of corpses and discards constituted $<1 \%$ of the diet of adult demersal fish in the model. The main beneficiary of discarded fish and corpses in the system was the carnivorous/scavenge feeding benthos $(13 \%$ of diet, $99 \%$ of all consumption of discards and corpses). Apart from fishery discarding, corpses were produced in the model by density dependent mortality. This encapsulated a variety of potential self-limitation processes which must be important for population regulation, including increased mortality risk of individuals unable to find limited refuge (Johnson, 2006), enhanced transmission of disease and parasites with host density (e.g. Mellergaard and Spanggard, 1997; Patterson, 1996), and in prey populations where predators aggregate and switch their prey preference in response to prey density (Bailey and Ainley, 1982; Johnson, 2006). The common property of all these processes is that per-capita mortality rates increase with abundance. Mathematically, the effect is to dampen fluctuations in population numbers, and models which lack any aspect of density dependence typically display oscillatory behavior or limitcycles, and fail to attain a stationary state (Edwards and Brindley, 1999; Franks, 2002). Hence, some simple representation of density dependent mortality is almost always included in population or ecosystem dynamics models, partly as a numerical necessity, but also as a caricature of the generic group process that must be occurring in the real world but about which we have only very limited understanding (Fulton et al., 2003b). The problem for nutrient-conserving ecosystem models is how to route the flux of material generated as a result of density dependent mortality. By explicitly including corpses in the model as a state variable receiving the outcome of density dependent mortality from the living guilds, the implication was that the key processes resulted in non-predation deaths rather than simply increasing predation risk. The structural effect was to create scavenging pathways in the food web in addition to the pathways defined by the living predator - prey preference matrix.

Anecdotal observations suggest that non-predation mortality occurs throughout the trophic range and that corpses are food for a wide range of scavengers (e.g whale corpse being scavenged by flocks of birds at sea (W. Melle pers.comm.); scenescent scyphomedusae carpet on the seabed being consumed by hyperiid amphipods (author, personal observation in Loch Linnhe, west of Scotland)). Video recording of scavengers attracted to carrion bait is a widely used method for assessing the abundance and diversity of species, especially fish, in many difficult-to-sample habitats (King et al., 2007)..Nevertheless, there are few if any quantitative measurements of the fluxes of carrion in the food web. A component of corpses in the sea, and in the model, arise from fishery discards. Kaiser and Hiddink (2007) calculated that scavenging of fishery discards represented only $0.8 \%$ of the food demands of benthos in the North Sea, which was insufficient to offset the reduction in benthos production caused by damage due to fishing operations. Other studies have similarly concluded that discards represent only a small fraction of benthos food requirements (e.g. Groenewold and Fonds, 2000), but may be important for some species of seabirds (Furness et al., 2007). However, the proportion of total carrion which is due to discards remains un-quantified.

In addition to fishing, the top-level of the model food web was represented by a predation term representing seabirds and marine mammals. However, unlike fishing which was a sink for nutrient i.e. there was no closed return of nutrient to the ecosystem from the fish that were landed, the predation by birds and mammals was returned to the system as corpses, detritus and ammonia. The magnitude of predation 
by birds and mammals in the North Sea is somewhat uncertain since population census estimates are difficult to obtain and the annual diets of some species are poorly known, but we included results from the analysis by Bryant and Doyle (1992) in the target data set for fitting of the model parameters (diet composition: $49-54 \%$ pelagic fish, $35-48 \%$ demersal fish, and $4-11 \%$ discards). The simulated diet composition in the maximum likelihood model fit was $85 \%$ pelagic fish, $15 \%$ demersal fish, $<1 \%$ discards.

\subsection{Closing remarks}

It is important to emphasize that these model results should not be over-interpreted. Inherent in the functional group modelling approach is the assumption that the characteristics of the group, as represented by the uptake and physiological parameters remain constant over all conditions. Changes in speciation would be expected to violate this assumption. In reality, some of the simulations were extreme situations, for example where pelagic fish were exploited to near-extinction in the model, and although the model predicted that demersal fish continue to exist with a diet composed almost exclusively of benthos and zooplankton, there is no suggestion that this could happen in reality without catastrophic consequences for the species composition of the demersal fish guild. Essentially, all the major piscivorous fish in the group which rely on small pelagic fish in their adult diet would disappear and be replaced by benthivores, or have to undergo massive changes in behaviour. In these extremes, the representation of all piscivorous and benthivorous fish as a demersal guild with a constant parameterization is too crude. But, the purpose of the model was to diagnose the gross consequences of fishing due to the interaction between bottomup and top-down effects in the food web, not to represent detail at any particular level. Resolving details would require a different modelling approach allowing representation of more finely resolved taxa, probably at the expense of other parts of the system. A likely way forward is to combine the end-to-end ecosystem, guild-based approach taken here, with a multi-species partial food web modelling approach, in which the focus is on a subset of key species of interest, and the production rates of groups of species more remote in a trophic sense from the central focus are derived from the sort of model described here.

\subsection{Conclusions and practical implications for fisheries management}

The most important conclusion from this study is that fisheries for pelagic and demersal fish guilds cannot be considered in isolation from each other. Direct predator-prey interactions between pelagic and demersal fish, and indirect interactions through the zooplankton food web, lead to strong inter-dependence of pelagic and demersal fishery yields. This conclusion is at odds with a strand of the literature which suggests that variations in MSY of a species or guild of fish can be explained by variations in primary production, and by implication that maximum yields are essentially set by bottom-up forcing (Cheung et al., 2008, 2010). In part, this perception arises from meta-anlyses of data from wide ranging ecosystems which shows a positive relationship between mean annual primary production and fisheries yield (e.g. Chassot et al., 2007). Whilst it is certainly reasonable to propose that all other factors being equal, then variations in nutrient input to an ecosystem should translate into proportionate changes in fisheries yield, the model shows that this is by no means the case when harvesting patterns are varied. The maximum equilibrium 
biomass yield from the ecosystem was revealed only when demersal fish were harvested to extinction and the fish yield consisted solely of pelagic fish.

The model has potential to benefit fisheries management since it can be used to analyze the distribution of fishing effort across coarsely defined fleets (the balance between pelagic, demersal and shellfish harvesting) which would be required to achieve ecologically sustainable exploitation. Rather than setting harvesting targets independently for each of the main exploited species which risk being incompatible, the model offers a means of setting internally consistent guild level harvesting targets with the objective of maximizing overall outputs (biomass, economic, or social) from the system and maintaining non-target groups (e.g. birds and mammals) within chosen ranges of abundance, for given scenarios of 'climate' (nutrient inputs, advection and vertical mixing). Once a high-level strategy such as this has been established, then single species models can be deployed to address the more detailed break-down of guild-level harvesting rates among species.

\section{Acknowledgements}

This work was developed over a number of years with support along the way from the EU-RECLAIM project (EC FP 6, 044133 (SSP8)), Scottish Government project MF0758, and EURO-BASIN (EC FP7, 264933). In addition, the author was supported for part of the time by the MASTS research pooling initiative from the Scottish Funding Council. The concept and development of the project were greatly influenced by many discussions with Professor John Steele, for which I am very grateful. Thanks also to Morten Skogen at IMR Bergen for providing volume transport data from NORWECOM model outputs, and to Jens Rasmussen at Marine Scotland for assembling the relationship between vertical attenuation coefficient and turbidity. Thanks also to the two anonymous reviewers who made extensive suggestions for improving the manuscript.

\section{References}

Bailey, K.M. Ainley, D.G., 1982. The dynamics of California sea lion predation on Pacific hake. Fisheries Research 1, 163-176.

Bertsimas, D., Tsitsiklis, J., 1993. Simulated annealing. Statistical Science 8, 10-15.

Bisagni, .JJ., 2003. Seasonal variability of nitrate supply and potential new primary production in the Gulf of Maine and Georges Bank regions. Journal of Geophysical Research 108 C11: 8015, doi:10.1029/2001JC001136

Brion, N., Baeyens, W., de Galani, S., Elskens, M., Laane, R.W.P.M., 2004. The North Sea: source or sink for nitrogen and phosphorus to the Atlantic Ocean? Biogeochemistry 68, 277-296.

Broekhuizen, N., Heath, M.R., Hay, S.J., Gurney, W.S.C., 1995. Modelling the dynamics of the North Sea's zooplankton. Netherlands Journal of Sea Research 33(3/4), 381-406.

Bryant, A.D., Doyle, P., 1992. Static predation loading estimation for North Sea top predators. ERSEM Progress Report January 1992, Annex 6: 1-16 (EU MAST I project CT90-0021)

Cerny, V., 1985. A thermodynamic approach to the travelling salesman problem: An efficient simulation. Journal of Optimization Theory and Applications 54, 4151 . 
Chassot, E., Mélin, F., Le Pape, O., Gascuel, D., 2007. Bottom-up control regulates fisheries production at the scale of eco-regions in European seas. Marine Ecology Progress Series 343, 45-55.

Cheung, W.W.L., Close, C., Lam, V., Watson, R., Pauly, D., 2008. Application of macroecological theory to predict effects of climate change on global fisheries potential. Marine Ecology Progress Series 365, 187-197.

Cheung, W.W.L., Lam, V.W.Y., Sarmiento, J.L., Kearney, K., Watson, R., Zeller, D., Pauly, D., 2010. Large-scale redistribution of maximum fisheries catch potential in the global ocean under climate change. Global Change Biology 16, 24-35.

Collie, J. S., Gifford, D. J., Steele, J. H., 2009. End-to-end foodweb control of fish production on Georges Bank. ICES Journal of Marine Science 66: 2223-2232.

Dann, N., Bromley, P.J., Hislop, J.R.G., Nielsen, N.A., 1990. Ecology of North Sea fish. Netherlands Journal of Sea Research 26, 343-386.

de Valpine, P., and Hastings, A., 2002. Fitting population models incorporating process noise and observation error. Ecological Monographs 72, 57-76.

Dugdale, R.C., Goering, J.J., 1967. Uptake of new and regenerated forms of nitrogen in primary productivity. Limnology and Oceanography 12, 196-206

Edwards, A.M., Brindley, J., 1999. Zooplankton mortality and dynamical behaviour of plankton population models. Bulletin of Mathematical Biology 61, 303-339.

Eppley, R.W., Peterson, B.J., 1979. Particulate organic matter flux and planktonic new production in the deep ocean. Nature 282, 677-680

Evans, G.T., Parslow, J.S., 1985. A model of annual plankton cycles. Biological Oceanography 3, 327-347.

Fennel, W., 2010. A nutrient to fish model for the example of the Baltic Sea. Journal of Marine Systems 81, 184-195.

Frank, K.T., Petrie, B., Shackell, N.L., 2007. The ups and downs of trophic control in continental shelf ecosystems. Trends in Ecology and Evolution 22, 236-42. doi:10.1016/j.tree.207.03.002

Franks, P.J.S., 2002. NPZ models of plankton dynamics: their construction, coupling to physics, and application. Journal of Oceanography 58, 379-387.

Fulton, A., 2009. Approaches to end-to-end ecosystem models. Journal of marine Systems 81, 171-183

Fulton, E.A., Parslow, J.S., Smith, A.D.M., Johnson, C.R., 2004a. Biogeochemical marine ecosystem models II: the effect of physiological detail on model performance. Ecological Modelling 173, 371-406.

Fulton, E.A., Smith, A.D.M., Johnson, C.R., 2003a. Effect of complexity on marine ecosystem models. Marine Ecology Progress Series 253, 1-16.

Fulton, E.A., Smith, A.D.M., Johnson, C.R., 2003b. Mortality and predation in ecosystem models: is it important how these are expressed? Ecological Modelling 169, 157-178.

Fulton, E.A., Smith, A.D.M., Johnson, C.R., 2004b. The effects of spatial resolution on the performance and interpretation of marine ecosystem models. Ecological Modelling 176, 27-42.

Furness, R.W., Edwards, A.E., Oro, D., 2007. Influence of management practices and of scavenging seabirds on availability of fisheries discards to benthic scavengers. Marine Ecology Progress Series 350, 235-244.

Gaichas, S.K., Aydin, K.Y., Francis, R.C., 2010. Using food web model results to inform stock assessment estimates of mortality and production for ecosystem 
based fisheries management. Canadian Journal of Fisheries and Aquatic Sciences 67, 1490-1506.

Greenstreet, S.P.R., Bryant, A.D., Broekhuizen, N., Hall, S.J., Heath, M.R., 1997. Seasonal variation in consumption of food by fish in the North Sea and implications for food web dynamics. ICES Journal of Marine Science 54, 243266.

Greenstreet, S. P. R., Rogers, S. I., Rice, J. C., Piet, G. J., Guirey, E. J., Fraser, H. M., Fryer, R. J., 2010. Development of the EcoQO for the North Sea fish community. ICES Journal of Marine Science (DOI 10.1093/icesjms/fsq156).

Groenewold, S., Fonds, M., 2000. Effects on benthic scavengers of discards and damaged benthos produced by the beam-trawl fishery in the southern North Sea. ICES Journal of Marine Science 57, 1395-1406.

Hall, S.J., Collie, J.S., Duplisi, D.E., Jennings, S., Bravington, M., Link, J., 2006. A length-based multispecies model for evaluating community responses to fishing. Canadian Journal of Fisheries and Aquatic Science 63, 1344-1359.

Hartig, F., Calabrese, J.M., Reineking, B., Wiegand, T., Huth, A., 2011. Statistical inference for stochastic simulation models - theory and application. Ecology Letters 14, 816827.

Heath, M.R., 2005. Changes in the structure and function of the North Sea fish food web, 1973-2000, and the impacts of fishing and climate. ICES Journal of Marine Science 62, 847-868.

Heath, M.R., 2007a. Spatially resolved monthly riverine fluxes of oxidised nitrogen (nitrate and nitrite) to the European shelf seas, 1960-2005. FRS Internal Report 02/07: 59p www.scotland.gov.uk/Uploads/Documents/0207.pdf accessed 10 May 2011.

Heath, M.R., 2007b. The consumption of zooplankton by fish early life history stages in the North Sea. ICES Journal of Marine Science 64, 1650-1663.

Heath, M.R., Beare, D.J., 2008. New primary production in northwest European shelf seas, 1960-2003. Marine Ecology Progress Series 363, 183-203.

Heath, M.R., Edwards, A.C., Pätsch, J., Turrell, W.R., (2002). Modelling the behaviour of nutrients in the coastal waters of Scotland. Fisheries Research Services Report 10/02. 107pp.

www.scotland.gov.uk/Uploads/Documents/ersem report final.pdf accessed 10 May 2011.

Heath, M.R., Lough, R.G., 2007. A synthesis of large scale patterns in the planktonic prey of larval and juvenile cod. Fisheries Oceanography 16, 169-185.

Hilborn, R., Mangel, M., 1997. The ecological detective : confronting models with data. Princeton, N.J.: Princeton University Press, 1997. Series: Monographs in population biology, 28.

Hollowed, A.B., Bax, N., Beamish, R., Collie, J., Fogarty, M., Livingston, P., Pope, J. and Rice, J.C., 2000. Are multispecies models an improvement on singlespecies models for measuring fishing impacts on marine ecosystems? ICES Journal of Marine Sceince 57, 707-719.

Hunsicker, M.E., Ciannelli, L., Bailey, K.M., Buckel, J.A., White, J.W., Link, J.S., Essington, T.E., Gaichas, S., Anderson, T.W., Brodeur, R.D., Chan, K.-S., Chen, K., Englund, G., Frank, K.T., Freitas, V., Hixon, M.A., Hurst, T., Johnson, D.W., Kitchell, J.F., Reese, D., Rose, D.A., Sjodin, H., Sydeman, W.J., van der Veer, H.W., Vollset, K. and Zador, S., 2011. Functional responses and scaling in predator-prey interactions of marine fishes: contemporary issues and emerging concepts. Ecology Letters, (2011) doi: 10.1111/j.1461-0248.2011.01696.x 
Hydes, D.J., Kelly-Gerreyn, B.A., Le Gall, A.C., Proctor, R., 1999. The balance of supply of nutrients and demands of biological production and denitrification in a temperate latitude shelf sea - a treatment of the southern North Sea as an extended estuary. Marine Chemistry 68, 117-131.

ICES, 2004a. Report of the Herring Assessment Working Group for the area south of $62^{\circ} \mathrm{N}$ (HAWG). ICES Document, CM 2004/ACFM: 18.

ICES, 2004b. Report of the Working Group on the Assessment of Demersal Stocks in the North Sea and Skagerrak. ICES Document, CM 2004/ACFM:07.

ICES, 2004c. Report of the Working Group on the Assessment of Mackerel, Horse Mackerel, Sardine and Anchovy (WGMHSA). ICES Document, CM 2004/ACFM:08.

Ito, S-I., Yoshie, N., Okunishi, T., Ono, T., Okazaki, Y., Kuwata, A., Hashioka, T., Rose, K.A., Megrey, B.A., Kishi, M.J., Nakamachi, M., Shimizu, Y., Kakehi, S., Saito, H., Takahashi, K., Tadokoro, K., Kusaka, A., Kasai, H., 2010. Application of an automatic approach to calibrate the NEMURO nutrient-phytoplankton-zooplankton food web model in the Oyashio region. Progress in Oceanography 87, 186-200. doi: 10.1016/j.pocean. 2010.08.004

Johnson, D.W., 2006. Density dependence in marine fish populations revealed at small and large spatial scales. Ecology 87, 319-325.

Jones, R., Henderson, E.W., 1987. The dynamics of nutrient regeneration and simulation studies of the nutrient cycle. Journal du Conseil international pour l'Explorations de la Mer 43, 216-236.

Kaiser, M.J., Hiddink, J.G., 2007. Food subsidies from fisheries to continental shelf benthic scavengers. Marine Ecology Progress Series 350, 267-276.

Kavanagh, P., Newlands, N., Christensen, V., Pauly, D., 2004. Automated parameter optimization for Ecopath ecosystem models. Ecological Modelling 172, 141-149.

King, N.J., Bailey, D.M., Priede, I.G., 2007. Introduction: Theme Section on Role of scavengers in marine ecosystems. Marine Ecology Progress Series 350, 175178.

Kinzey, D., Punt, A.E., 2009. Multispecies and single-species models of fish population dynamics: comparing parameter estimates. Natural Resource Modeling 22, 67-104.

Kirkpatrick, S., Gelett, C.D., Vecchi, M.P., 1983. Optimisation by simulated annealing. Science 220, 621-630.

Kuroda, H., Kishi, M.J., 2004. A data assimilation technique applied to estimate parameters for the NUMERO marine ecosystem model. Ecological Modelling $172,69-85$.

Law, C.S., Owens, N.J.P., 1990. Denitrification and nitrous oxide in the North Sea. Netherlands Journal of Sea Research 25, 65-74.

Lenhart, H.J., Radach, G., Backhaus, J.O., Pohlmann, T., 1995. Simulations o fthe North Sea circulation, its variability, and its implementation as hydrodynamical forcing in ERSEM. Netherlands Journal of Sea Research 33 (3/4), 271-299.

Lohse, L., Kloosterhuis, H.T., van Raaphorst, W., Helder, W., 1996. Denitrification rates as measured by the isotope pairing method and by the acetylene inhibition technique in continental shelf sediments of the North Sea. Marine Ecology Progress Series 132, 169-179.

Mackinson, S., Daskalov, G., 2007. An ecosystem model of the North Sea to support an ecosystem approach to fisheries management: description and parameterisation. Scientific Series Technical Report, Cefas Lowestoft, 142, $195 \mathrm{pp}$. 
Mackinson, S., Deas, B., Beveridge, D. Casey, J., 2009. Mixed fishery or ecosystem conundrum? Multispecies considerations inform thinking on long-term management of North Sea demersal stocks. Canadian Journal of Fisheries and Aquatic Sciences 66, 1107-1129.

Matear, R.J., 1995. Parameter optimization and analysis of ecosystem models using simulated annealing: A case study at Station P. Journal of Marine Research 53, 571-607.

Mellergaard, S., Spanggard, B., 1997. An Icthyophonus hoferi epizootic in herring in the North Sea, the Skagerrak, the Kattegat and the Baltic. Diseases of Aquatic Organisms 28, 191-199.

Mueter, F.J., Megrey, B.A., 2006. Using multi-species surplus production models to estimate ecosystem-level maximum sustainable yields. Fisheries Research 81, $189-201$

Murawski, S.A., 2000. Definitions of overfishing from an ecosystem perspective. ICES Journal of Marine Science 57, 649-658.

Patterson, K.R., 1996. Modelling the impact of disease-induced mortality in an exploited population: the outbreak of the fungal parasite (Icthyophonus hoferi) in the North Sea herring (Clupea harengus). Canadian Journal of Fisheries and Aquatic Sciences 53, 2870-2887.

Pitcher, T.J., Cochrane, K., (Eds), 2002. The use of ecosystem models to investigate multi-species management strategies for capture fisheries. Workshop 17th20th July 2000, Vancouver. FCRR 2002, Vol. 10(2), 156pp.

Plagányi, É.E., 2007. Models for an ecosystem approach to fisheries. FAO Fisheries Technical Paper. No. 477. Rome, FAO. 2007. 108p.

Pohlmann, T., 1996. Calculating the annual cycle of the vertical eddy viscosity in the North Sea with a three-dimensional baroclinic shelf sea circulation model. Continental Shelf Research 16, 147-161.

Pohlmann, T., Puls, W., 1994. Currents and transport in water. In: Sundermann, J. (Ed.), Circulation and contaminant fluxes in the North Sea. Springer Verlag, Berlin, pp. 345-402.

R Development Core Team, 2005. R: A language and environment for statistical computing. R Foundation for Statistical Computing, Vienna, Austria. ISBN 3900051-07-0, URL http://www.R-project.org.

Radach, G., Lenhart, H.J., 1995 Nutrient dynamics in the North Sea: Fluxes and budgets in the water column derived from ERSEM. Netherlands Journal of Sea Research 33 (3/4), 301-335.

Redfield, A.C., Ketchum, B.H., Pritchard, F.A., 1963 The influence of organisms on the composition of seawater. In: The Sea, vol 2 [Hill, N., ed.]. Interscience, New York.

Riley, G.A., Stommel, H., Bumpus, D.F., 1949. Quantitative ecology of the plankton of the western North Atlantic. Bulletin of the Bingham Oceanography Collection 12, 1-169.

Rogers, S., Casini, M., Cury, P., Heath,M., Irigoien,X., Kuosa, H., Scheidat, M., Skov, H., Stergiou, K., Trenkel, V., Wikner, J., Yunev, O., 2010. Marine Strategy Framework Directive Task Group 4 Report. Food webs. EUR Scientific and Technical Research series, EUR 24343 EN, 55 pp. Luxemburg, Germany: Office for Official Publications of the European Communities. (doi:10.2788/87659).

Rose, K.A., Allen, J.I., Artioli, Y., Barange, M., Blackford, J., Carlotti, F., Daewel, U., Edwards, K., Flynn, K., Hill, S.L., HillerRisAlmbers, R., Huse, G. Mackinson, S., Megrey, B., Moll, A., Rivkin, R., Salihoglu, B., Schrum, C., 
Shannon, L., Shin, Y.-J., Smith, S.L., Smith, C., Solidoro, C., St John, M., Zhou, M., 2010. End-to-end models for the analysis of marine ecosystems: challenges, issues, and next steps. Marine and Coastal Fisheries: Dynamics, Management, and Ecosystem Science 2, 115-130. DOI: 10.1577/C09-059.1

Ross, A.H., Gurney, W.S.C., Heath, M.R., 1994. A comparative study of the ecosystem dynamics of four fjords. Limnology and Oceanography 39, 318343.

Ruardij, P., van Raaphorst, W., 1995. Benthic nutrient regeneration in the ERSEM ecosystem model of the North Sea. Netherlands Journal of Sea Research. 33(34), 453-483.

Shelton, A.O., Mangel, M., 2011. Fluctuations of fish populations and the magnifying effects of fishing. Proceedings of the National Academy of Sciences 108, 7075-7080.

Simpson, D., Fagerli, H.J., Jonson, J.E., Tsyro, S., Wind, P., Tuovinen, J.-P., 2003. Transboundary Acidification, Eutrophication and Ground Level Ozone in Europe. EMEP Status Report 1/2003 PART I Unified EMEP Model Description., Norwegian Meteorological Institute, Oslo, Norway. 104pp

Skogen, M.D., Moll, A., 2005 Importance of ocean circulation in ecological modelling: An example from the North Sea. Journal of Marine Systems 57, 289-300.

Skogen, M.D., Søiland, H., 1998. A User's guide to NORWECOM v2.0. The NORWegian ECOlogicalModel system. Technical report Fisken og Havet 18/98. Institute of Marine Research. Pb 1970, N-5024 Bergen. 42pp

Skogen, M., Svendsen, E., Ostrowski, M., 1997. Quantifying volume transports during SKAGEX with the Norwegian Ecological Model system. Continental Shelf Research 17, 1817-1837.

Smith, S.V., Hollibaugh, J.T., 1993. Coastal metabolism and the oceanic organic carbon balance. Revues in Geophysics 31, 75-89.

Sparholt, H., Cook, R.M., 2010. Sustainable exploitation of temperate fish stocks. Biology Letters 6, 124-127.

Speirs, D.C., Guirey, E.J., Gurney, W.S.C., Heath, M.R., 2010. A length structured partial ecosystem model for cod in the North Sea. Fisheries Research 106, 474-494.

Steele, J.H., 1958. Plant production in the northern North Sea. Marine Research, 7, 136. Scottish Home Department.

Steele, J.H., 1974. The structure of marine ecosystems. Harvard Univ Press, Cambridge, Mass. 128pp.

Steele, J.H.., Collie, J.S., Bisagni, J.J., Gifford, D.J., Fogarty, M.J., Link, J.S., Sullivan, B.K., Sieracki, M.E., Beet, A.R., Mountain, D.G., Durbin, E.G., Palka, D., Stockhausen, W.T., 2007. Balancing end-to-end budgets of the Georges Bank ecosystem. Progress in Oceanography 74, 423-448.

Steele, J.H., 2008. Assessment of some linear food web methods. Journal of Marine Systems 76, 186-194.

Tarrasón, L., 2003. Transboundary Acidification, Eutrophication and Ground Level Ozone in Europe. EMEP Status Report 1/2003 Part II, Unified EMEP Model Performance, Norwegian Meteorological Institute, Oslo, Norway. 170pp

Tyrrell, M.C., Link, J.S., Moustahfid, H., 2011. The importance of including predation in fish population models: implications for biological reference points. Fisheries Research 108, 1-8.

van Boxtel, A.M.J.V., von Koningslow, M., Tossings ,F.M., 1991. Atmospheric deposition of nutrients into the North Sea: assessment of possible effects on 
algae growth. Geosense B.V. by order of the Ministry of Public Works and Transport. North Sea Directorate, The Netherlands, 60 p.

van Raaphorst, W., Kloosterhuis, H.T., Cramer, A., Bakker, K.J.M., 1990. Nutrient early diagenesis in the sediments of the Dogger Bank area, North Sea: pore water results. Netherlands Journal of Sea Research 26, 25-52.

Ward, B.B., 2005. Temporal variability in nitrification rates and related biogeochemical factors in Monterey Bay, California, USA. Marine Ecology Progress Series 292, 97-109.

Wood, S.N., 2010. Statistical inference for noisy nonlinear ecological dynamics. Nature 466, 1102-1104.

Yool, A,. Martin, A.P., Fernández, C., Clark, D.R., 2007. The significance of nitrification for oceanic new production. Nature 447, 999-1002 (doi:10.1038/nature05885). 


\section{Appendix 1. Estimation of climatological fish harvesting and discarding rates}

In order to estimate the proportion of fish and benthos guild biomasses caught per day (harvest rate), the landings ratio (proportion of guild biomass landed per day) was first derived from landings and stock assessment data, and then divided by the ratios of landed : caught weights which were derived from published monitoring data.

Annual mean stock biomass of the two fish guilds during the period 19731999 was estimated by extrapolating from the biomasses of the 10 fish species in the North Sea which are assessed by ICES Working Groups (ICES, 2004a,b,c). Catch-atage analysis outputs were assembled for each of these species (pelagic guild: Atlantic herring, Atlantic mackerel, sandeel, Norway pout; demersal guild: cod, haddock, whiting, saithe, common sole, plaice; see Heath, 2005 for details). The average number $(\mathrm{N})$ of fish in an age class over the interval $t$ (1st January of the current year) to $\mathrm{t}+1$ (1st January the following year) was derived from the stock numbers-at-age tables:

$\overline{N_{(t)-(t+1)}}=\left(\frac{-N_{t}}{\left(\ln \left(N_{t}\right)-\ln \left(N_{t+1}\right)\right)}\right) \cdot\left(e^{-\left(\ln \left(N_{t}\right)-\ln \left(N_{t+1}\right)\right)}-1\right)$

(see Heath, 2007b)

The annual average biomass in the age class was then:

$\overline{B_{(t)-(t+1)}}=\overline{N_{(t)-(t+1)}} \cdot \overline{W_{(t)-(t+1)}}$

where $\overline{W_{(t)-(t+1)}}$ was the annual average individual weight of fish in the age class as provided in the stock assessment reports. Summing over all age classes in the assessment provided an estimate of the annual mean stock biomass for each species. Summing over species in each guild provided a partial estimate of guild biomass, for the assessed subset of species. Total guild biomass was then estimated by applying the proportion of guild biomass contributed by assessed species, as estimated from annual trawl survey data (Dann et al., 1990; see Heath, 2005 for further details).

Annual landed weights of fish species from the North Sea during the years 1970-1999 were obtained from the STATLANT database maintained by ICES (http://www.ices.dk/fish/CATChSTATISTICS.asp accessed 20 February 2012). These comprise yearly landed weights of fish and shellfish officially submitted by the 19 ICES member countries in the Northeast Atlantic. The data were accessed using the FAO Fishbase+ database system.

The STATLANT data were differentiated by species but not by age or size class. To estimate the daily landings ratio the species in the STATLANT data set were grouped according to guilds (see Heath, 2005 for guild assignment of STATLANT species), and divided by the guild biomass as estimated above. The annual landed weight was assumed to have been uniformly distributed through the year.

Mackinson and Daskalov (2007) estimated discarded weights of commercial and non-commercial species in 1991 by applying discard : landed weight ratios derived from data collected by observers on UK registered vessels between 1994 and 2007, to the total international landed weights in 1991. Here, the 1991 discard and landed weights were summed across all the species in each fish guilds to estimate the guild-level values of the ratio of catch : landings. Catch ratios in year y were the derived as: 


$$
\left(\frac{\text { Guild catch }}{\text { Guildbiomass }}\right)_{y}=\left(\frac{\text { Guildlandings }}{\text { Guildbiomass }}\right)_{y} \cdot\left(\frac{1991 \text { guild landings }+1991 \text { guild discards }}{1991 \text { guild landings }}\right)
$$

The procedure for estimating the catch ratio of benthic invertebrate guilds (benthic carnivores and benthic suspension/deposit feeders) was essentially the same, except that estimates of the biomass of taxa in each guild, derived from benthic survey data, were available only for 1991 (Mackinson and Daskalov, 2007). Landed weights of benthos species were extracted from the STATLANT dataset, and discarded weights of benthos from Mackinson and Daskalov (2007).

\section{Appendix 2. Model parameter fitting by simulated annealing}

Starting with the hand-fitted parameter set and a repeating annual cycle of driving data, the model was run until the results passed a stationarity test over the final annual cycle (all state variable concentrations differed by less than a factor of 0.00001 between day 1 and day 360; typically achieved within 80 years), and the model state at the end of the run was saved. All model runs in the simulated annealing scheme were then initialized from this saved state. Denoting the hand-fitted parameter vector $\theta[0]$, the procedure was to iterate for $\mathrm{k}=1,2,3 \ldots$, and at each iteration the fitting parameters were 'jiggled' by proposing $\theta^{*}=\theta[\mathrm{k}-1]+\delta[\mathrm{k}]$, where $\delta[\mathrm{k}]$ was a vector of random values from a gaussian distribution of mean 0 and standard deviation given by a fixed coefficient of variation applied to the current value of each parameter in the class or classes selected for fitting $\left(\theta_{\text {current }}=\theta[\mathrm{k}-1]\right)$. Where preference parameters were included in the process, the values were renormalized to 1.0 for each predator after the addition of $\delta[\mathrm{k}]$. The model was then run for 10 years, which was sufficient for an acceptably stationary solution, and a new value computed for the likelihood $\mathrm{P}\left(\right.$ observations $\left.\mid \theta^{*}\right)$.

The change in performance of the model due to the proposed jiggled parameter vector was measured by $\left(\chi_{\theta^{*}}{ }^{2}-\chi_{\theta \text { current }}{ }^{2}\right)$. A simple hill-climbing scheme would accept the proposed vector $\theta^{*}$ as a new version of $\theta_{\text {current }}$ for the next iteration only if the likelihood ratio $\exp \left(-\chi_{\theta^{*}}{ }^{2}+\chi_{\theta \text { current }}{ }^{2}\right)>1$. Over many iterations $\theta_{\text {current }}$ should then migrate towards a maximum liklihood fit. However, such schemes are notorious for becoming trapped in local optima. Simulated annealing attempts to mitigate this risk by accepting a proportion of instances of $\theta^{*}$ which produce worse results than $\theta_{\text {current }}($ i.e. likelihood ratio $<1$ ), thereby exploring a wider range of the parameter space. The process is an analogy of the way in which crystals form in a metal as it cools. Taking $\Gamma[\mathrm{k}]$ to represent the 'temperature' of the system at iteration $\mathrm{k}$, the probability of accepting $\theta^{*}$ as the new $\theta_{\text {current }}$ is equal to the modified likelihood ratio $L_{m r}=\exp \left(\left(-\chi_{\theta^{*}}{ }^{2}+\chi_{\theta \text { current }}{ }^{2}\right) / \Gamma[\mathrm{k}]\right)$. The value of $\Gamma[\mathrm{k}]$ is allowed to 'cool' as the iterations progress (increasing $\mathrm{k}$ ). As $\Gamma[\mathrm{k}]$ approaches 0 the system assumes a simple hill-climbing mode (i.e. only vectors $\theta^{*}$ producing likelihood ratios $>1$ are accepted). In the early stages, when $\Gamma[\mathrm{k}]>>0$, a proportion of $\theta^{*}$ producing likelihood ratios $<1$ are accepted. Practically, after each model run $\theta[\mathrm{k}]=\theta^{*}$ only if $L_{m r} \geq \mathrm{P}_{\mathrm{R}}$ where $\mathrm{P}_{\mathrm{R}}$ was drawn from a uniform random distribution between 0 and 1 , otherwise $\theta[\mathrm{k}]=$ $\theta[\mathrm{k}-1]$ for the next iteration. At each iteration, both the currently accepted and the proposed parameter vectors were saved, along with the resulting likelihood of the observations given the parameters.

The sequence of $\mathrm{P}($ observed $\mid \theta)[\mathrm{k}])$ should converge to a maximum value representing the best attainable fit between the model and the observations given the model structure and driving data. However, the rate at which convergence is achieved, 
and potentially the converged vector itself, are dependent on the cooling schedule and the magnitude of the jiggling coefficient of variation $(\mathrm{cv})$ used to generate $\delta[\mathrm{k}]$. A geometrically decreasing temperature was applied $(\Gamma[\mathrm{k}]=\mathrm{r} \cdot \Gamma[\mathrm{k}-1])$, and after experimentation with the value of $\mathrm{r}$ and $\mathrm{cv}$, the finally adopted values were: $\mathrm{r}=$ $0.975, \mathrm{cv}=0.02)$ to achieve consistency of convergence within a sensible number of iterations $(<1000)$. The best-fit value of $\theta[\mathrm{k}]$ was regarded as being that remaining when no new parameter vectors were accepted within 200 iterations.

Simulated annealing is guaranteed to yield improvements in the model fit if achievable, but not necessarily the unique maximum likelihood fit, especially when the parameter space is large and the likelihood surface is complex. To test the degree to which individual parameters were constrained by the observations and the dependency of the maximum likelihood parameter vector on the initial values, each parameter in class or classes selected for fitting was perturbed, or 'kicked', by a random value drawn from a Gaussian, and the annealing process repeated. A further check was carried out by adopting the model output generated with the maximum likelihood parameter vector as a new set of target data, kicking the maximum likelihood parameters in the selected class or classes, and then running the annealing process to check whether the method recovered the maximum likelihood vector with likelihood 1.

To investigate the sensitivity of the model to individual parameters, correlation coefficients were derived between the sequences of proposed parameter values and the resulting likelihoods, for the converged phase of an annealing run (during which no new parameter vectors were accepted). During this sequence, proposed values of every parameter should be symmetrically distributed around the current accepted bestfit value, and variations between parameters should be completely un-correlated except in the case of the preference parameters which were renormalized on each iteration. Parameter variations were expressed as the modulus of the coefficient of variation (cv) of each proposed value in the sequence from the current accepted value. The correlation coefficient was then calculated between the series of cv's for each parameter and the resulting likelihoods. The expectation was for a significant inverse relationship between the cv's and resulting likelihoods for parameters which had a strong individual effect on the model. 
Table 1

Physical configuration parameters of the model.

\begin{tabular}{|c|c|c|}
\hline Parameter and units & Value & Source \\
\hline $\begin{array}{l}\text { Surface layer thickness }(\mathrm{m}) \\
\text { (mean depth of layer bounded } \\
\text { by the sea surface, and the } \\
\text { seabed or } 30 \mathrm{~m} \text {, whichever } \\
\text { shallower) }\end{array}$ & 28 & $\begin{array}{l}\text { Derived from ETOPO5 } 5 \text { min gridded } \\
\text { elevation dataset (National Geophysical } \\
\text { Data Centre, } \\
\text { www.ngdc.noaa.gov/mgg/global/global.htm) }\end{array}$ \\
\hline $\begin{array}{l}\text { Deep layer thickness }(\mathrm{m}) \\
\text { (mean thickness of layer } \\
\text { bounded by } 30 \text { and the } \\
\text { seabed, where seabed deeper } \\
\text { than } 30 \mathrm{~m} \text { ) }\end{array}$ & 42 & $\begin{array}{l}\text { Derived from ETOPO5 } 5 \text { min gridded } \\
\text { elevation dataset (National Geophysical } \\
\text { Data Centre, } \\
\text { www.ngdc.noaa.gov/mgg/global/global.htm) }\end{array}$ \\
\hline $\begin{array}{l}\text { Bottom boundary layer } \\
\text { thickness }(\mathrm{m}) \text { (for feeding by } \\
\text { suspension feeding benthos) }\end{array}$ & 20 & Estimated \\
\hline Sediment layer thickness $(\mathrm{m})$ & 0.1 & Law and Owens 1990 \\
\hline Sediment porosity $\left(\mathrm{m}^{3} \cdot \mathrm{m}^{-3}\right)$ & 0.45 & Ruardij \& Raaphorst 1995; Heath et al. 2002 \\
\hline $\begin{array}{l}\text { Sediment-water diffusion } \\
\text { coefficient }\left(\mathrm{m}^{2} \cdot \mathrm{s}^{-1}\right)\end{array}$ & $10^{-8}$ & $\begin{array}{l}\text { Ruardij \& Raaphorst 1995; van Raaphorst et } \\
\text { al.,1990 }\end{array}$ \\
\hline $\begin{array}{l}\text { Length scale for sediment- } \\
\text { water diffusion }(\mathrm{m})\end{array}$ & 0.01 & $\begin{array}{l}\text { Ruardij \& Raaphorst 1995; van Raaphorst et } \\
\text { al.,1990 }\end{array}$ \\
\hline
\end{tabular}


Table 2

Time-dependent oceanographic driving data required by the model and their derivation.

\begin{tabular}{|c|c|c|}
\hline Driving data & Derivation & Data source \\
\hline $\begin{array}{l}\text { Vertical diffusion } \\
\text { coefficient per unit } \\
\text { length }\left(\mathrm{V}(\mathrm{t}), \mathrm{m}^{2} \cdot \mathrm{s}^{-1}\right)\end{array}$ & $\begin{array}{l}\text { Climatological monthly average values } \\
\text { for sub-regions of the North Sea } \\
\text { combined with area weighting, to } \\
\text { produce a monthly resolution time } \\
\text { series for the whole North Sea. }\end{array}$ & $\begin{array}{l}\text { Lenhart et al. (1995) } \\
\text { and Pohlmann (1996). }\end{array}$ \\
\hline $\begin{array}{l}\text { Length scale for } \\
\text { vertical diffusivity } \\
\left(\mathrm{T}_{\mathrm{Vsd}}(\mathrm{t}), \mathrm{m}\right)\end{array}$ & $\begin{array}{l}\text { Linear variation between a value of } \\
(1.0) x(\text { seabed depth) at mean winter } \\
\text { values of vertical diffusivity }\left(\log _{\mathrm{e}} \mathrm{V}(\mathrm{t})=\right. \\
-1.8) \text { and }(0.4) \mathrm{x}(\text { seabed depth) at } \\
\text { summer values in the northern stratified } \\
\text { parts of the North Sea }\left(\log _{\mathrm{e}} \mathrm{V}(\mathrm{t})=-3.5\right) \text {. }\end{array}$ & Lenhart et al. (1995) \\
\hline $\begin{array}{l}\text { Temperature }(\mathrm{TZ}(\mathrm{t}) \text {, } \\
\left.{ }^{\circ} \mathrm{C}\right)\end{array}$ & $\begin{array}{l}\text { Individual hydrographic casts between } \\
1970 \text { and } 2000 \text { averaged over ICES sub- } \\
\text { areas and depth layers, by month and } \\
\text { year. For each month, the median and } \\
\text { quantiles of the annual values were then } \\
\text { calculated. Sub-area medians and } \\
\text { quantiles for each layer were then } \\
\text { combined to derive North Sea wide } \\
\text { values by volumetric weighted } \\
\text { averaging }\end{array}$ & $\begin{array}{l}\text { ICES Environmental } \\
\text { Data Centre }\end{array}$ \\
\hline $\begin{array}{l}\text { Ocean boundary } \\
\text { transport rates } \mathrm{I}_{\mathrm{s}}(\mathrm{t}) \text {, } \\
\mathrm{I}_{\mathrm{d}}(\mathrm{t})\left(\mathrm{m}^{3} \cdot \mathrm{d}^{-1}\right)\end{array}$ & $\begin{array}{l}\text { Median and quantiles of monthly } \\
\text { averaged volume inflow and outflow } \\
\text { rates to the upper }(0-30 \mathrm{~m}) \text { and lower } \\
\text { ( } 30 \mathrm{~m}-\text { seabed) layers through each of } \\
\text { the four model boundaries, calculated } \\
\text { over years in the period } 1970-2000 \text {. The } \\
\text { total volume inflow to the North Sea } \\
\text { was the sum of the inflows through the } \\
\text { boundary sections }\end{array}$ & $\begin{array}{l}\text { Monthly averaged } \\
\text { volumes of from the } \\
\text { NORWECOM ocean } \\
\text { circulation model } \\
\text { (courtesy of Morten } \\
\text { Skogen, IMR Norway; } \\
\text { Skogen et al., 1997, } \\
\text { Skogen and Soiland, } \\
\text { 1998). }\end{array}$ \\
\hline $\begin{array}{l}\text { Freshwater inputs } \\
\left(\mathrm{m}^{3} \cdot \mathrm{d}^{-1}\right)\end{array}$ & $\begin{array}{l}1960-2005 \text { monthly averaged } \\
\text { freshwater discharge rates and were } \\
\text { estimated for the three ICES sub-areas } \\
\text { separately by summing the inputs over } \\
\text { relevant segments of coastline, and } \\
\text { summed to provide the discharge rate } \\
\text { for the whole North Sea. }\end{array}$ & Heath (2007a). \\
\hline
\end{tabular}


Table 3

Time-dependent nutrient input and concentration data required by the model and their derivation.

\begin{tabular}{|c|c|c|}
\hline Driving data & Derivation & Data source \\
\hline $\begin{array}{l}\text { Flow-weighted } \\
\text { concentrations of } \\
\text { nitrate and } \\
\text { ammonia in } \\
\text { freshwater inputs }\end{array}$ & $\begin{array}{l}\text { 1960-2005 monthly averaged nutrient } \\
\text { discharge rates estimated for the three } \\
\text { ICES sub-areas separately by } \\
\text { summing the inputs over relevant } \\
\text { segments of coastline, and summing to } \\
\text { provide input rates for the whole } \\
\text { North Sea. Flow weighted } \\
\text { concentration was then the input rate } \\
\text { divided by the freshwater discharge } \\
\text { rate over the same period. }\end{array}$ & Heath (2007a). \\
\hline $\begin{array}{l}\text { Atmospheric } \\
\text { deposition of } \\
\text { nitrate and } \\
\text { ammonia }\end{array}$ & $\begin{array}{l}50 \times 50 \mathrm{~km}^{2} \text { gridded data on annual } \\
\text { atmospheric deposition rates of total } \\
\text { oxidized and reduced nitrogen for the } \\
\text { years } 1980,1985,1990,1995 \text { and } \\
2000 \text { averaged over grid cells } \\
\text { corresponding to the North Sea. }\end{array}$ & $\begin{array}{l}\text { Co-operative Programme for } \\
\text { Monitoring and Evaluation of } \\
\text { the Long-range Transmission } \\
\text { of Air pollutants in Europe } \\
\text { (EMEP) Unified } 50 \text { x } 50 \mathrm{~km}^{2} \\
\text { grid model (revision 1.7; } \\
\text { Simpson et al., 2003; Tarrasón } \\
2003 \text {; } \\
\text { www.emep.int/Model_data/yea } \\
\text { rly_data.html; accessed } 11 \text { Jan } \\
2008 \text { ) }\end{array}$ \\
\hline $\begin{array}{l}\text { Ocean boundary } \\
\text { concentrations }\end{array}$ & $\begin{array}{l}\text { Individual analyses of water samples } \\
\text { collected in each } 0-30 \mathrm{~m} \text { and }>30 \mathrm{~m} \\
\text { depth layers between } 1970 \text { and } 2000 \\
\text { were averaged over spatial } \\
\text { compartments aligned with the } 4 \text { open } \\
\text { boundaries of the North Sea (Fig. 2). } \\
\text { For each month, the median and } \\
\text { quantiles of the annual values were } \\
\text { calculated. Medians and quantiles for } \\
\text { boundary were then combined to } \\
\text { derive North Sea wide values by } \\
\text { volumetric weighted averaging based } \\
\text { on the monthly averaged inflow } \\
\text { volume. }\end{array}$ & $\begin{array}{l}\text { Individual sample nitrate, } \\
\text { ammonia, and chlorophyll data } \\
\text { from the ICES Environmental } \\
\text { Data Centre. } \\
\text { Phytoplankton-nitrogen and } \\
\text { detritus-nitrogen } \\
\text { estimated by scaling from } \\
\text { chlorophyll. } \\
\text { Carbon:chlorophyll (g.g }{ }^{-1} \text { ) was } \\
\text { assumed to be } 40 \text {, along with } \\
\text { molar Redfield nitrogen:carbon } \\
\text { (16:106; Redfield et al., 1963). } \\
\text { Deep suspended detritus was } \\
\text { assumed to be 10-times the } \\
\text { nitrogen mass of } \\
\text { phytoplankton. The surface } \\
\text { boundary concentration of } \\
\text { suspended detritus was } \\
\text { assumed to be zero. }\end{array}$ \\
\hline
\end{tabular}


Table 4

Time-dependent irradiance and attenuation driving data required by the model and their derivation.

\begin{tabular}{|c|c|c|}
\hline Driving data & Derivation & Source \\
\hline $\begin{array}{l}\text { Sea surface } \\
\text { irradiance } \\
\left(\mathrm{L}(\mathrm{t}), \mathrm{E} \mathrm{m}^{-2} \mathrm{~d}^{-1}\right)\end{array}$ & $\begin{array}{l}30 \mathrm{~d} \text { averages of a resolution } \\
\text { sinusoidal function, varying over } \\
360 \mathrm{~d} \text { between a seasonal } \\
\text { maximum (on day } 180 \text { ) and } \\
\text { minima (on days } 0 \text { and } 360 \text { ). }\end{array}$ & $\begin{array}{l}\text { Seasonal maximum and } \\
\text { minimum from } 15 \text { min average } \\
\text { irradiances measured } \\
\text { continuously during } 2007-2008 \\
\text { at Aberdeen, UK (latitude } 57^{\circ} \\
15^{\prime} \text { N) (Marine Scotland Science, } \\
\text { unpublished data). }\end{array}$ \\
\hline $\begin{array}{l}\text { North Sea monthly } \\
\text { averaged } \\
\text { suspended } \\
\text { particulate matter } \\
(\mathrm{SPM})\left(\mathrm{mg} \cdot \mathrm{m}^{-3}\right)\end{array}$ & $\begin{array}{l}\text { Monthly averaged SPM in the } \\
\text { surface layer over the area of the } \\
\text { North Sea derived from simulated } \\
\text { data. These values then used to } \\
\text { estimate the vertical attenuation of } \\
\text { irradiance. }\end{array}$ & $\begin{array}{l}\text { Simulated data set on SPM } \\
\text { concentrations in the North Sea } \\
\text { (1/5 latitude x } 1 / 3 \text { degree } \\
\text { longitude spatial resolution, } 5 \mathrm{~d} \\
\text { temporal resolution for a 1980's } \\
\text { climatological year) (Pohlmann } \\
\text { and Puls, 1994). }\end{array}$ \\
\hline $\begin{array}{l}\text { Relationship } \\
\text { between SPM and } \\
\text { vertical attenuation } \\
\text { of surface } \\
\text { irradiance }(\text { Kvert }(\mathrm{t}) \\
\left.\left(\log _{\mathrm{e}}\right), \mathrm{m}^{-1}\right)\end{array}$ & $\begin{array}{l}\text { Parameterised from a pair of } \\
\text { relationships linking a) vertical } \\
\text { attenuation and turbidity } \\
\text { (Formazine Turbidity Units, } \\
\text { FTU), and b) turbidity and } \\
\text { suspended particulate matter } \\
\text { (SPM, mg m }{ }^{-3} \text { ) } \\
\text { a) Kvert }=0.1775+0.061(\mathrm{FTU}) \text {; } \\
\mathrm{r}^{2}=0.646, \mathrm{n}=140, \mathrm{p}<0.01\end{array}$ & $\begin{array}{l}\text { a) Vertical profiles of irradiance } \\
\text { and turbidity measured weekly } \\
\text { during } 2007-2008 \text { at } 57^{\circ} \mathrm{N} 2^{\circ} \mathrm{W} \\
\text { (Marine Scotland Science, } \\
\text { unpublished data). Attenuation } \\
\text { coefficients derived from the } \\
\text { irradiance data, turbidity } \\
\text { averaged over } 0-10 \mathrm{~m} \text { depth. } \\
\text { b) Simulated annual cycle of } \\
\text { SPM in a region centered on the } \\
\text { weekly sampling site }\left(56.9^{\circ} \mathrm{N}-\right. \\
57.1^{\circ} \mathrm{N}, 2.2^{\circ} \mathrm{W}-1.9^{\circ} \mathrm{W}, 5 \mathrm{~d} \text { time } \\
\text { intervals) extracted from } \\
\text { Pohlmann and Puls }(1994) \text { and } \\
\text { related to the time series of } \\
\text { depth averaged }(0-10 \mathrm{~m}) \\
\text { turbidity, }\end{array}$ \\
\hline
\end{tabular}


Table 5

Step-by-step procedure for estimating climatological fish harvesting and discarding rates. Steps H, G and I use the products of earlier steps in the process, as indicated by letters in the left-hand column.

\begin{tabular}{|c|c|c|c|}
\hline Step & Derived property & Data source & References to data \\
\hline A & $\begin{array}{l}\text { Annual average biomasses of } \\
\text { assessed species in each guild, for } \\
\text { years } 1973-1999 . \\
\text { Demersal guild: cod, haddock, } \\
\text { whiting, saithe, plaice, common } \\
\text { sole,; Pelagic guild: mackerel, } \\
\text { herring sandeel, Norway pout). }\end{array}$ & $\begin{array}{l}\text { Stock assessment data } \\
\text { (numbers at age on } 1 \\
\text { January, and annual } \\
\text { mean weight at age, } \\
\text { by year, for each } \\
\text { species. }\end{array}$ & ICES, 2004a,b,c \\
\hline $\mathrm{B}$ & $\begin{array}{l}\text { Ratios of assessed finfish species } \\
\text { biomass to total biomass for each } \\
\text { guild (pelagic, demersal). }\end{array}$ & $\begin{array}{l}\text { Annual International } \\
\text { Bottom Trawl Survey } \\
\text { data. }\end{array}$ & $\begin{array}{l}\text { Dann et al., } 1990 \\
\text { and } \\
\text { http://datras.ices.dk } \\
\text { /Home/Default.asp } \\
\text { (accessed 20 Feb } \\
\text { 2012) }\end{array}$ \\
\hline $\mathrm{C}$ & $\begin{array}{l}\text { Annual finfish and benthos species } \\
\text { landings by year summed over } \\
\text { guilds. }\end{array}$ & $\begin{array}{l}\text { Annual species } \\
\text { landings data held in } \\
\text { the FAO/ICES } \\
\text { STATLANT database. }\end{array}$ & $\begin{array}{l}\text { http://www.ices.dk } \\
\text { fish/CATChSTATI } \\
\text { STICS.asp } \\
\text { (accessed } 20 \mathrm{Feb} \\
\text { 2012) }\end{array}$ \\
\hline $\mathrm{D}$ & 1991 biomass of each benthos guild. & $\begin{array}{l}\text { Species abundances } \\
\text { recorded in the } 1991 \\
\text { North Sea Benthos } \\
\text { Survey Database. }\end{array}$ & $\begin{array}{l}\text { Mackinson and } \\
\text { Daskalov, } 2007\end{array}$ \\
\hline $\mathrm{E}$ & $\begin{array}{l}\text { Proportions of directed finfish and } \\
\text { benthos guild catch weights which } \\
\text { are discarded. }\end{array}$ & $\begin{array}{l}\text { Data from observers } \\
\text { aboard fishing vessels } \\
\text { in 1991, recording } \\
\text { species catch, landings } \\
\text { and discards. }\end{array}$ & $\begin{array}{l}\text { Mackinson and } \\
\text { Daskalov, } 2007\end{array}$ \\
\hline $\mathrm{F}$ & $\begin{array}{l}\text { Finfish and benthos guild annual } \\
\text { landed weight as proportions of } \\
\text { biomass. }\end{array}$ & $\begin{array}{l}\mathrm{C} /(\mathrm{A} / \mathrm{B}) \text { for finfish } \\
\text { and } \mathrm{C} / \mathrm{D} \text { for benthos }\end{array}$ & \\
\hline G & $\begin{array}{l}\text { Finfish and benthos guild annual } \\
\text { catch weight as a proportion of } \\
\text { biomass (harvest rate). }\end{array}$ & $\mathrm{F} /(1-\mathrm{E})$ & \\
\hline $\mathrm{H}$ & $\begin{array}{l}\text { Benthos by-catch in demersal finfish } \\
\text { fisheries as a proportion of benthos } \\
\text { biomass. }\end{array}$ & $\begin{array}{l}\text { Data from observers } \\
\text { aboard fishing vessels } \\
\text { in 1991, recording } \\
\text { species, landings and } \\
\text { discards. }\end{array}$ & $\begin{array}{l}\text { Mackinson and } \\
\text { Daskalov, } 2007\end{array}$ \\
\hline $\mathrm{I}$ & $\begin{array}{l}\text { Benthos by-catch harvesting rate as a } \\
\text { proportion of demersal harvesting } \\
\text { rate. }\end{array}$ & $\mathrm{H} / \mathrm{G}_{\text {Demersal }}$ & \\
\hline
\end{tabular}


Table 6

Summary measures of primary production, based on nitrogen fluxes. Carbon flux equivalents were calculated assuming Redfield equivalence between nitrogen and carbon. Units in each case were mMN.m ${ }^{-2} \cdot \mathrm{y}^{-1}$.

\begin{tabular}{|c|c|}
\hline Abbreviation & Description \\
\hline NIP & Annual integral of the nitrate uptake rate by algae. \\
\hline PNP & $\begin{array}{l}\text { Potential New Production: the sum of annual vertical fluxes of } \\
\text { nitrate into the photic layer plus the net horizontal fluxes of } \\
\text { nitrate through the photic zone (i.e. horizontal imports less } \\
\text { exports). This should be equal to uptake of nitrate in the surface } \\
\text { layer by algae and denitrifying bacteria, less the production of } \\
\text { nitrate in the surface layer by nitrification of ammonia. This } \\
\text { definition of PNP corresponds to that calculated by Bisagni } \\
\text { (2003), except that Bisagni disregarded the horizontal flux term. }\end{array}$ \\
\hline MMP & $\begin{array}{l}\text { The difference, on an annual basis, between the maximum and } \\
\text { minimum values of nitrate concentrations integrated from } \\
\text { surface to seabed (Heath and Beare, 2008). }\end{array}$ \\
\hline IP & $\begin{array}{l}\text { Annual lateral rate of input of inorganic } \mathrm{N} \text { (nitrate }+ \text { ammonia) } \\
\text { into the region from rivers, atmospheric deposition and } \\
\text { exchange across the shelf edge. Calculated from river and } \\
\text { deposition data, and estimates of advection across the shelf edge } \\
\text { (Heath and Beare, 2008). }\end{array}$ \\
\hline MMIP & $\begin{array}{l}\text { Sum of MMP plus that part of IP occurring between the julian } \\
\text { dates of maximum and minimum depth integrated nitrate values } \\
\text { (Heath and Beare, 2008). }\end{array}$ \\
\hline TAPP & $\begin{array}{l}\text { Total annual primary production: the annually integrated sum of } \\
\text { autotrophic uptake rates of nitrate plus ammonia. }\end{array}$ \\
\hline
\end{tabular}


Table 7

Phase independent annual production rates, fluxes between guilds, and annual ratios, and their standard deviations, derived from observations and from the maximum likelihood fit of the model. Observed units of production rates and fluxes, $\mathrm{gC} \cdot \mathrm{m}^{-2} \cdot \mathrm{y}^{-1}$, except for denitrification $(*), \mathrm{mMN} \cdot \mathrm{m}^{-2} \cdot \mathrm{y}^{-1}$. Model results computed as $\mathrm{mMN} / \mathrm{m} 2 / \mathrm{y}$ and carbon equivalent values estimated assuming Redfield molar proportions $(\mathrm{C}: \mathrm{N}=$ $106 / 16)$. Partial $\chi_{\theta}{ }^{2}$ between individual observed and modeled indices calculated as in the text, overall likelihood given by $\exp \left(-\left(\operatorname{mean}\left(\chi_{\theta}{ }^{2}\right)\right)\right.$. Literature sources of observed data: (1) Brion et al. (2004); (2) Bryant and Doyle (1992); (3) Heath (2005); (4) Heath and Beare (2008); (5) Mackinson and Daskalov (2007); (6) Skogen and Moll (2005).

\begin{tabular}{|c|c|c|c|c|c|c|}
\hline & $\begin{array}{c}\text { Observed } \\
\text { mean }\end{array}$ & Observed sd & $\begin{array}{c}\text { Model } \\
\text { nitrogen } \\
\text { units } \\
\end{array}$ & $\begin{array}{c}\text { Model } \\
\text { carbon } \\
\text { equivalent }\end{array}$ & $\begin{array}{c}\text { Partial } \\
\chi_{\theta}^{2} \\
\end{array}$ & $\begin{array}{c}\text { Reference } \\
\text { to } \\
\text { observed } \\
\text { data } \\
\end{array}$ \\
\hline Units & $\mathrm{gC} / \mathrm{m} 2 / \mathrm{y} *$ & $\mathrm{gC} / \mathrm{m} 2 / \mathrm{y} *$ & $\mathrm{mMN} / \mathrm{m} 2 / \mathrm{y}$ & $\mathrm{gC} / \mathrm{m} 2 / \mathrm{y}$ & & \\
\hline \multicolumn{7}{|l|}{ Annual production rates } \\
\hline Total annual primary & 121 & 12 & 1506.63 & 119.78 & 0.0052 & 6 \\
\hline New primary (MMIP) & 50.4 & 5.4 & 700.42 & 55.68 & 0.4827 & 4 \\
\hline Denitrification $*$ & $129 *$ & $42 *$ & 37.49 & 2.98 & 2.3738 & 1 \\
\hline Herbivorous zooplankton & 27 & 7.7 & 253.33 & 20.14 & 0.4014 & 3,5 \\
\hline Carnivorous zooplankton & 3.53 & 0.82 & 25.97 & 2.06 & 1.5762 & 3,5 \\
\hline Carnivorous benthos & 1.36 & 0.24 & 14.84 & 1.18 & 0.3024 & 3 \\
\hline $\begin{array}{l}\text { Pelagic fish } \\
\text { (larvae+adults) }\end{array}$ & 2.38 & 0.28 & 30.64 & 2.44 & 0.0182 & 3 \\
\hline $\begin{array}{l}\text { Demersal fish (larvae + } \\
\text { adults) }\end{array}$ & 0.91 & 0.18 & 10.34 & 0.82 & 0.1295 & 3 \\
\hline Pelagic fish landings & 0.49 & 0.06 & 4.878 & 0.388 & 1.5437 & 3 \\
\hline Demersal fish landings & 0.13 & 0.03 & 1.697 & 0.135 & 0.0135 & 3 \\
\hline Shellfish landings & 0.0068 & 0.0015 & 0.0752 & 0.0060 & 0.1619 & 3 \\
\hline Birds/mammals & 0.0003 & 0.0005 & 0.0023 & 0.0002 & 0.0107 & 5 \\
\hline \multicolumn{7}{|l|}{ Fluxes between guilds } \\
\hline $\begin{array}{l}\text { Herbivorous zoo. by } \\
\text { carnivorous zoo. }\end{array}$ & 4.80 & 2.00 & 71.95 & 5.72 & 0.1057 & \\
\hline Zooplankton by fish & 7.34 & 1.04 & 106.00 & 8.43 & 0.5545 & 3 \\
\hline Benthos by fish & 1.00 & 0.50 & 18.79 & 1.49 & 0.4882 & 3 \\
\hline Pelagic fish by other fish & 1.87 & 0.72 & 5.054 & 0.402 & 2.0706 & 3 \\
\hline $\begin{array}{l}\text { Demersal fish by other } \\
\text { fish }\end{array}$ & 0.17 & 0.04 & 1.960 & 0.156 & 0.0627 & 3 \\
\hline $\begin{array}{l}\text { Pelagic fish by } \\
\text { birds/mammals }\end{array}$ & 0.005 & 0.0012 & 0.0123 & 0.0010 & 6.1194 & 2 \\
\hline $\begin{array}{l}\text { Demersal fish by } \\
\text { birds/mammals }\end{array}$ & 0.001 & 0.0005 & 0.0022 & 0.0002 & 1.3496 & 2 \\
\hline $\begin{array}{l}\text { Discards by } \\
\text { birds/mammals }\end{array}$ & 0.001 & 0.0005 & 0.000041 & 0.000003 & 1.9868 & 2 \\
\hline \multicolumn{7}{|l|}{ Annual ratios } \\
\hline $\begin{array}{l}\text { Herbivorous zooplankton } \\
\mathrm{P} / \mathrm{B}\end{array}$ & 20 & 10 & 12.72 & 12.72 & 0.2652 & 5 \\
\hline $\begin{array}{l}\text { Carnivorous zooplankton } \\
\mathrm{P} / \mathrm{B}\end{array}$ & 2.63 & 1.32 & 4.875 & 4.875 & 1.4579 & 5 \\
\hline Pelagic fish larvae P/B & 4.00 & 2.00 & 3.167 & 3.167 & 0.0867 & 5 \\
\hline
\end{tabular}




\begin{tabular}{lllllll}
\hline Demersal fish larvae P/B & 4.00 & 2.00 & 3.083 & 3.083 & 0.1052 & 5 \\
\hline Carnivorous benthos P/B & 1.50 & 1.00 & 3.302 & 3.302 & 1.6239 & 5 \\
\hline $\begin{array}{l}\text { Suspension/deposit } \\
\text { feeding benthos P/B }\end{array}$ & 2.10 & 0.44 & 2.254 & 2.254 & 0.0630 & 5 \\
\hline Pelagic fish adults P/B & 1.72 & 0.86 & 0.697 & 0.697 & 0.7078 & 5 \\
\hline Demersal fish adults P/B & 0.88 & 0.44 & 0.567 & 0.567 & 0.2533 & 5 \\
\hline Birds/mammals P/B & 0.10 & 0.05 & 0.189 & 0.189 & 1.5872 & 5 \\
\hline $\begin{array}{l}\text { Demersal fish } \\
\text { discards/catch }\end{array}$ & 0.37 & 0.05 & 0.367 & 0.367 & 0.0015 & 5 \\
\hline \multicolumn{1}{l}{ Overall likelihood } & & & & & & \\
\hline
\end{tabular}


Table 8

Fishery harvesting and discarding rates estimated as the mean applicable over the period 1970-1999, derived as in Table 5.

Harvest ratio $\left(\mathrm{d}^{-1}\right) \quad$ Proportion of catch discarded

\begin{tabular}{lll}
\hline Adult pelagic fish & $7.10 \times 10^{-4}$ & 0.10 \\
\hline Adult demersal fish & $6.80 \times 10^{-4}$ & 0.37 \\
\hline Suspension/deposit feeding benthos & $4.92 \times 10^{-6}$ & 0.12 \\
\hline Carnivorous/scavenging benthos & $4.48 \times 10^{-6}$ & 0.12 \\
\hline
\end{tabular}




\section{Table 9}

Incidence of significant $(\mathrm{p}<0.05)$ correlation between random deviations around the maximum likelihood parameter value and the resulting likelihood of the model given the observed target data, for the converged sequence of a simulated annealing run (220 iterations with no new parameter vectirs accepted). The critical value of chisquared at $\mathrm{p}<0.05$ was 3.84 , so none of the parameter categories had a disproportionately high or low impact on the likelihood of the model.

\begin{tabular}{lccc}
\hline & $\begin{array}{l}\text { Cases of significant } \\
\text { correlation }\end{array}$ & $\begin{array}{l}\text { Non-significant } \\
\text { cases }\end{array}$ & $\begin{array}{l}\text { Chi- } \\
\text { squared }\end{array}$ \\
\hline Prey preferences & 17 & 12 & 0.232 \\
\hline Maximum uptake rates & 7 & 3 & 1.010 \\
\hline Half-saturation constnats & 5 & 5 & 0.070 \\
\hline $\begin{array}{l}\text { Density depedent mortality } \\
\text { coefficients }\end{array}$ & 2 & 5 & 1.847 \\
\hline Biogeochemical rate parameters & 8 & 7 & 0.004 \\
\hline Demersal discarding coefficient & 0 & 1 & 1.182 \\
\hline Total & 39 & 33 & \\
\hline
\end{tabular}


Table 10

Maximum likelihood equilibrium model values of measures of annual primary production. Descriptions of each measure in Table 6 .

$$
\underset{1}{\mathrm{mMN}} \cdot \mathrm{m}^{-2} \cdot \mathrm{y}^{-} \quad \mathrm{gC} \cdot \mathrm{m}^{-2} \cdot \mathrm{y}^{-1}
$$

\begin{tabular}{llcc}
\hline NIP & Annual uptake of nitrate & 1225.56 & 97.43 \\
\hline PNP & Potential new Primary Production & 1158.62 & 92.11 \\
\hline MMP & $\begin{array}{l}\text { New Production (derived from depth } \\
\text { integrated nitrate data) }\end{array}$ & 655.84 & 52.14 \\
\hline IP & Nitrogen import & 1521.59 & 120.97 \\
\hline MMIP & MMP + IP & 700.42 & 55.68 \\
\hline TAPP & Total Annual Primary production & 1506.63 & 119.78 \\
\hline
\end{tabular}


Table 11

Ratio of standard deviation to arithmetic mean, calculated over the harvesting rate space defined by the $7 \times 7$ matrix of pelagic and demersal fish harvesting rates.

\begin{tabular}{ll}
\hline & $\mathrm{sd} / \mathrm{mean}$ \\
\hline Winter surface layer nitrate concentration & 0.0023 \\
\hline Water column - sediment particulate flux & 0.0456 \\
\hline Annual denitrification & 0.0056 \\
\hline Total annual primary production & 0.0096 \\
\hline Herbivorous zooplankton production & 0.0836 \\
\hline Carnivorous zooplankton production & 0.5427 \\
\hline $\begin{array}{l}\text { Suspension/deposit feeding benthos } \\
\text { production }\end{array}$ & 0.0591 \\
\hline $\begin{array}{l}\text { Carnivorous/scavenging benthos } \\
\text { production }\end{array}$ & 0.0794 \\
\hline Pelagic fish production & 0.7154 \\
\hline Demersal fish production & 0.9113 \\
\hline Bird/mammal production & 1.5266 \\
\hline
\end{tabular}


Table 12

Import and export fluxes as estimated by Brion et al. (2004) compared to the model results.

Brion et al. 2004 Model simulations using (Fluxes during 1976- monthly resolved data and 1995) 1970-1999 median boundary and transport data

\begin{tabular}{llll}
\hline $\begin{array}{l}\text { Total N imports } \\
\text { kt.y }\end{array}$ & 8576 & 13244 \\
\hline & Advection inflow & 6190 & 11993 \\
\hline & Rivers/estuaries & 805 & 801 \\
\hline & Direct discharges & 70 & - \\
\hline & Nitrogen fixation & 0.000125 & - \\
\hline & $\begin{array}{l}\text { Atmospheric } \\
\text { deposition }\end{array}$ & 1631 & 450 \\
\hline $\begin{array}{l}\text { Total N exports } \\
\text { kt.y }\end{array}$ & 8576 & 13244 \\
\hline & Advection outflow & 6476 & 12900 \\
\hline & Denitrification & 2080 & 292 \\
\hline & Burial & 20 & - \\
\hline & Fishing & - & 52 \\
\hline
\end{tabular}


Fig. 1. Schematic of the structure of the ecosystem model. Grey-filled boxes represent model state variables. Suspended detritus, dissolved inorganic nutrient, and phytoplankton are resolved to water column layers, whilst zooplankton fish and birds/mammals exist as depth integrated populations. Exchange of suspended material between water column layers is by mixing and vertical advection. Exchange with the ocean involves both advective import and export terms, whilst river and atmospheric depositions represent inputs only. Emission of nitrogen gas generated by denitrification, and landings of fish, represent exports from the model.

Fig. 2. Schematic of the role of fishing in the model ecosystem. Grey-filled boxes represent model state variables. Fishing fleets 1-4 target adult pelagic fish, adult demersal fish, carnivorous/scavenging benthos, and filter \& deposit feeding benthos, with harvesting rates $X$. A proportion (disc) of the targeted catch by fleets 1,3 and 4, is retuned to the ecosystem as discards, the remainder is removed from the model as landings. Fleet 2 generates a by-catch harvesting rate on the two benthos categories, $100 \%$ of which is discarded. Discards are converted to corpses and then to detritus.

Fig. 3. Spatial domain of the model and boundary zones. Four open boundaries are shown by solid lines. Monthly volume transport fluxes were assembled for each boundary. The rectangular cells define the geographical coordinates used to collate information on boundary concentrations of nutrient and chlorophyll.

Fig. 4. 1970-1999 median physical diving data for the model. Sea surface irradiance $\left(E . \mathrm{m}^{-2} \cdot \mathrm{d}^{-1}\right)$, suspended particulate matter in the surface layer (SPM; mg. $\mathrm{m}^{-3}$ ), vertical diffusivity $\left(\mathrm{m}^{2} \cdot \mathrm{s}^{-1}\right)$, volume inflow to each layer across the open ocean boundaries (proportion of layer volume per day, $\mathrm{d}^{-1}$ ), volume input of freshwater from rivers to the surface layer (proportion of layer volume per day, $\mathrm{d}^{-1}$ ), layer averaged temperature $\left({ }^{\circ} \mathrm{C}\right)$. All data represent monthly average values.

Fig. 5. 1970-1999 median concentrations of nitrate and ammonia $\left(\mathrm{mMN} \cdot \mathrm{m}^{-3}\right)$ at the open boundaries of the model, derived as the volume weighted average of the data at each of the four North Sea boundary zones. Boundary concentrations of phytoplankton and suspended detritus nitrogen $\left(\mathrm{mMN} \cdot \mathrm{m}^{-3}\right)$ were scaled from observed chlorophyll concentrations.

Fig.6. 1970-1999 volume weighted median river nitrate and ammonia concentrations $\left(\mathrm{mMN} \cdot \mathrm{m}^{3}\right)$, and atmospheric fluxes of nitrate and ammonia $\left(\mathrm{mMN} \cdot \mathrm{m}^{-2} \cdot \mathrm{d}^{-1}\right)$ for the North Sea as a whole.

Fig. 7. Example of the evolution of a simulated annealing run of 1000 iterations. The initial parameter set for the model was derived by hand-fitting and jiggled by a random value drawn from a Gaussian of $\mathrm{sd} /$ mean $=0.02$ on each iteration. The annealing 'temperature' which dictated the probability of accepting a particular parameter proposal given the observations is shown by the dotted line and decreased geometrically as the simulation progressed.

Fig. 8. Recovery of maximum likelihood uptake rate parameters after a random perturbation. The maximum likelihood parameters were perturbed by a random Gaussian term with sd/mean of 0.2 , and simulated annealing run for 4000 iterations to assess the success at recovering the original parameter. All but two parameters 
migrated back to values close to their original. Uptake rates for pelagic and demersal fish larvae failed to return to their original values indicating that they were underconstrained by the observations.

Fig. 9. Simulated stationary values of monthy averaged nitrate, ammonia, chlorophyll, omnivorous and carnivorous zooplankton (filled symbols), compared to the long-term median values from observations (box and whisker plots).

Fig. 10. Annual nutrient inflows and outflows from the stationary model forced by 1970-1999 median driving data. All units, $m M N \cdot m^{-2} \cdot y^{-1}$. Net values for dissolved inorganic nitrogen (DIN), particulate organic nitrogen (PON), and nitrogen gas represent the sum of all imports minus the sum of all exports. Positive values indicate net import, negative indicate net export.

Fig 11. Annual production and feeding fluxes $\left(\mathrm{mMN} \cdot \mathrm{m}^{-2} \cdot \mathrm{y}^{-1}\right)$ in the stationary pelagic heterotrophic food web forced by 1970-1999 median driving data. Values within cells represent annual production rates, values associated with arrows represent feeding fluxes. Corresponding egg production and recruitment fluxes between larval and adult fish compartments were: pelagic egg production, 4.9; pelagic recruitment, 12.9; demersal egg production, 3.8, demersal recruitment, $7.8 \mathrm{mMN} \cdot \mathrm{m}^{-2} \cdot \mathrm{y}^{-1}$. Total annual primary production underpinning the web was $1506.6 \mathrm{mMN} \cdot \mathrm{m}^{-2} \cdot \mathrm{y}^{-1}$.

Fig. 12. Annual production and feeding fluxes $\left(\mathrm{mMN} \cdot \mathrm{m}^{-2} \cdot \mathrm{y}^{-1}\right)$ in the stationary benthic food web forced by 1970-1999 median driving data. Values within cells represent annual production rates, values associated with arrows represent feeding fluxes.

Fig 13. Stationary annual production and yields of pelagic fish in relation to pelagic and demersal harvesting rates with 1970-1999 median environmental forcing. Upper row, shaded plots with overlaid contours of (left) pelagic fish production (mMN.m ${ }^{-2} \cdot \mathrm{y}^{-}$ $\left.{ }^{1}\right)$, (right) pelagic fish catch (landings + discards, $\mathrm{mMN} \cdot \mathrm{m}^{-2} \cdot \mathrm{y}^{-1}$ ). Shading: light $=$ high values, dark $=$ low values, to aid visualization of the gradients shown by the contours. Axes of the contour plots represent pelagic and demersal harvesting rates relative to the 1970-1999 average, so the intersection of the vertical and horizontal white dashed lines $(1.0,1.0)$ indicates the case of the stationary fitted model. Middle row, pelagic fish production and yield (catch, solid line; landings, dashed line) in relation to pelagic harvesting with constant demersal harvesting at 1970-1999 rates, so representing a slice along the horizontal white dashed line in the top-row panels. Bottom row, pelagic fish production and yield (catch, solid line; landings, dashed line) in relation to demersal harvesting with constant pelagic harvesting at 1970-1999 rates, so representing a slice along the vertical white dashed line in the top-row panels.

Fig 14. As Figure 13, but for demersal fish production and yield. In this case, the middle row shows demersal production and yield in relation to demersal harvesting with constant pelagic harvesting at 1970-1999 rates. Similarly, the bottom row shows demersal production and yield in relation to pelagic harvesting with constant 19701999 demersal harvesting rates.

Fig. 15. Top row, maximum sustainable yield (MSY, mMN.m $\left.\mathrm{m}^{-2} \cdot \mathrm{y}^{-1}\right)$ of pelagic fish and the corresponding harvesting rate producing MSY ( $\mathrm{F}_{\mathrm{MSY}}$, relative to 1970-1999 rates), in relation to equilibrium demersal fish annual average biomass (mMN.m ${ }^{-2}$ ). 
Bottom row, same for demersal MSY and $F_{M S Y}$ in relation to pelagic fish annual average biomass. Solid lines represent MSY and corresponding $\mathrm{F}_{\mathrm{MSY}}$ based on yield = catch; dashed lines based on yield = landings.

Fig. 16. Left: demersal fish stationary annual production:biomass ratio $\left(\mathrm{P}: \mathrm{B} ; \mathrm{y}^{-1}\right)$ in relation to the annual proportion by nitrogen weight of fish in the diet of demersal fish. Right: shaded contour plot of proportion by nitrogen weight of fish in the diet of demersal fish in relation to demersal and pelagic harvesting rates (scaled relative to 1970-1999). Contour plot details as in Fig. 13 (light shading $=$ high values, dark $=$ low).

Fig 17. Shaded contour plots of early life stage performance of pelagic and demersal fish (measured as the ratio of stationary annual recruitment flux : annual egg production flux) due to changes in pelagic and demersal harvesting rates. Contour plot details as in Fig. 13 (light shading = high values, dark = low).

Fig. 18. Stationary annual production rates $\left(\mathrm{mMN} \cdot \mathrm{m}^{-2} \cdot \mathrm{y}^{-1}\right)$ of omnivorous (upper row) and carnivorous (lower row) zooplankton in relation to pelagic and demersal fish annual average biomass $\left(\mathrm{mMN} \cdot \mathrm{m}^{-2}\right)$.

Fig. 19. Early life stage performance of pelagic and demersal fish (measured as the ratio of stationary annual recruitment flux : annual egg production flux) in relation to omnivorous zooplankton annual production $\left(\mathrm{mMN} \cdot \mathrm{m}^{-2} \cdot \mathrm{y}^{-1}\right)$.

Fig. 20. Left: stationary annual landings $\left(\mathrm{mMN} \cdot \mathrm{m}^{-2} \cdot \mathrm{y}^{-1}\right)$ of shellfish (suspension/deposit feeding and carnivorous feeding benthos) in relation to pelagic and demersal harvesting rates with shellfish harvesting rates held constant at 19701999 rates. Right: annual discards of benthos $\left(\mathrm{mMN} \cdot \mathrm{m}^{-2} \cdot \mathrm{y}^{-1}\right)$ from both shellfish and demersal fisheries combined in relation to pelagic and demersal harvesting rates with shellfish harvesting rates held constant at 1970-1999 rates. Contour plot details as in Fig. 13 (light shading $=$ high values, dark $=$ low).

Fig. 21. Dynamics of suspension/deposit feeding benthos in relation to pelagic and demersal harvesting. Top left: stationary annual production $\left(\mathrm{mMN} \cdot \mathrm{m}^{-2} \cdot \mathrm{y}^{-1}\right)$. Top right: annual production:biomass ratio $\left(\mathrm{y}^{-1}\right)$. Bottom left: annual predation mortality : biomass ratio $\left(\mathrm{y}^{-1}\right)$. Bottom right: relationship between annual predation mortality : biomass ratio $\left(\mathrm{y}^{-1}\right)$ and annual average biomass of adult demersal fish $\left(\mathrm{mMN} \cdot \mathrm{m}^{-2}\right)$. Contour plot details as in Fig. 13 (light shading = high values, dark = low).

Fig. 22. . Dynamics of carnivorous feeding benthos in relation to pelagic and demersal harvesting. Top left: stationary annual production $\left(\mathrm{mMN} \cdot \mathrm{m}^{-2} \cdot \mathrm{y}^{-1}\right)$. Top right: annual production:biomass ratio $\left(\mathrm{y}^{-1}\right)$. Bottom left: annual predation mortality : biomass ratio $\left(\mathrm{y}^{-1}\right)$. Bottom right: annual average biomass of corpses $\left(\mathrm{mMN} \cdot \mathrm{m}^{-2}\right)$. Contour plot details as in Fig. 13 (light shading = high values, dark = low).

Fig. 23. Stationary food consumption and diet composition of birds/mammals in relation to pelagic and demersal harvesting rates. Top left: annual food consumption $\left(\mathrm{mMN} \cdot \mathrm{m}^{-2} \cdot \mathrm{y}^{-1}\right)$. Top right: proportion by weight of the annual diet comprising pelagic fish. Bottom left: proportion by weight of the annual diet comprising demersal fish. Bottom right: proportion by weight of the annual diet comprising carrion (discards 
and corpses). Contour plot details as in Fig. 13 (light shading $=$ high values, dark $=$ low). 


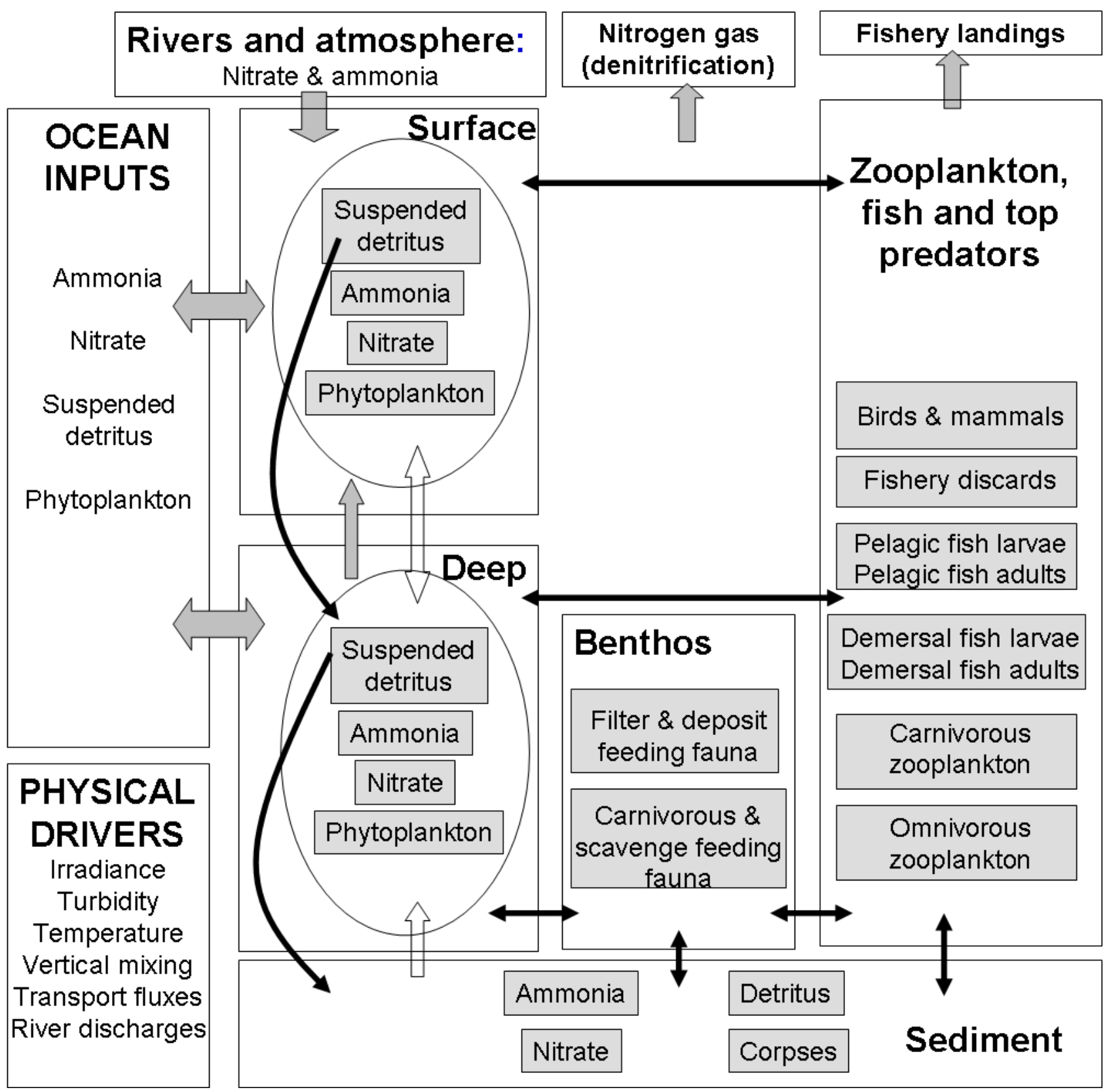




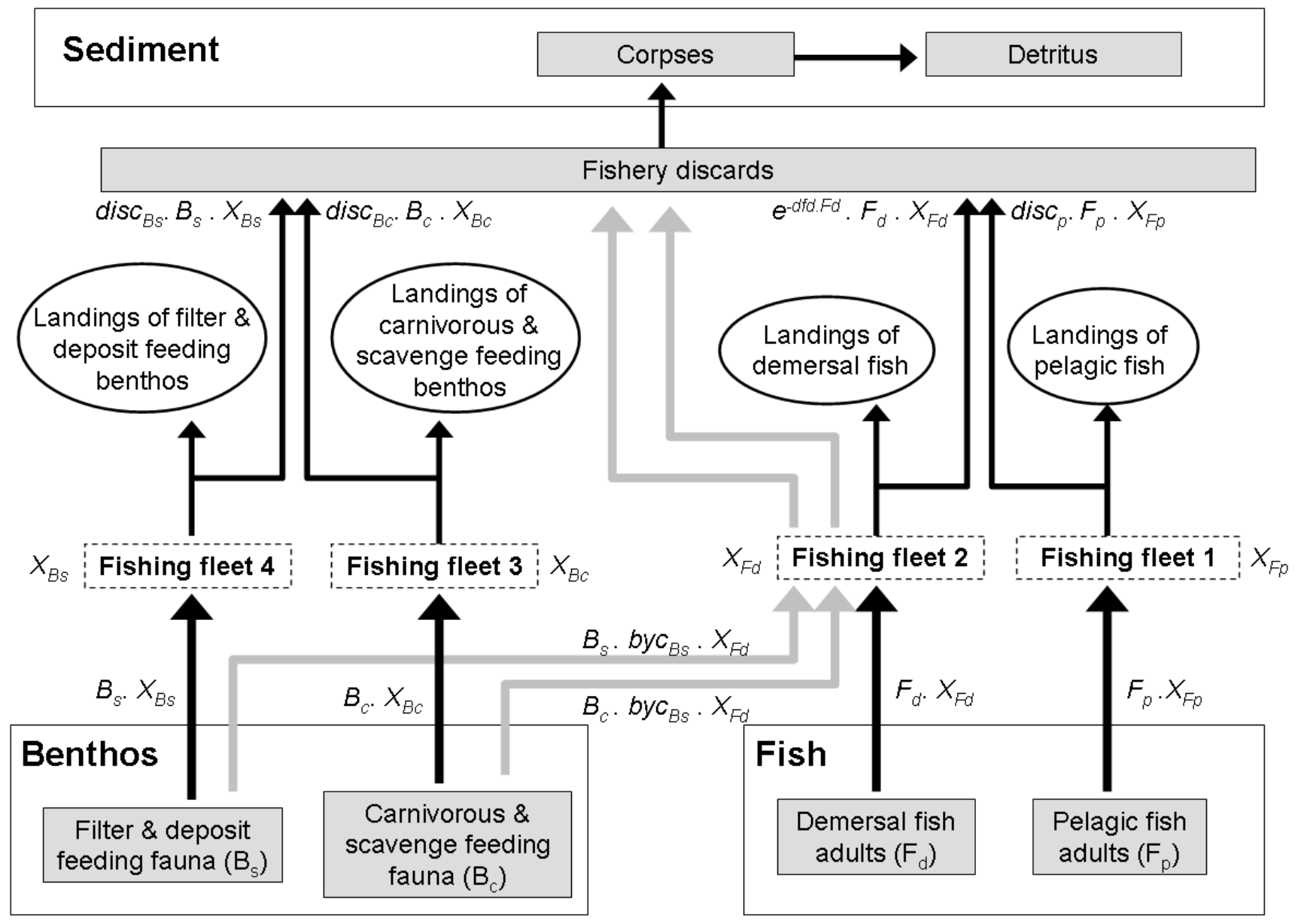




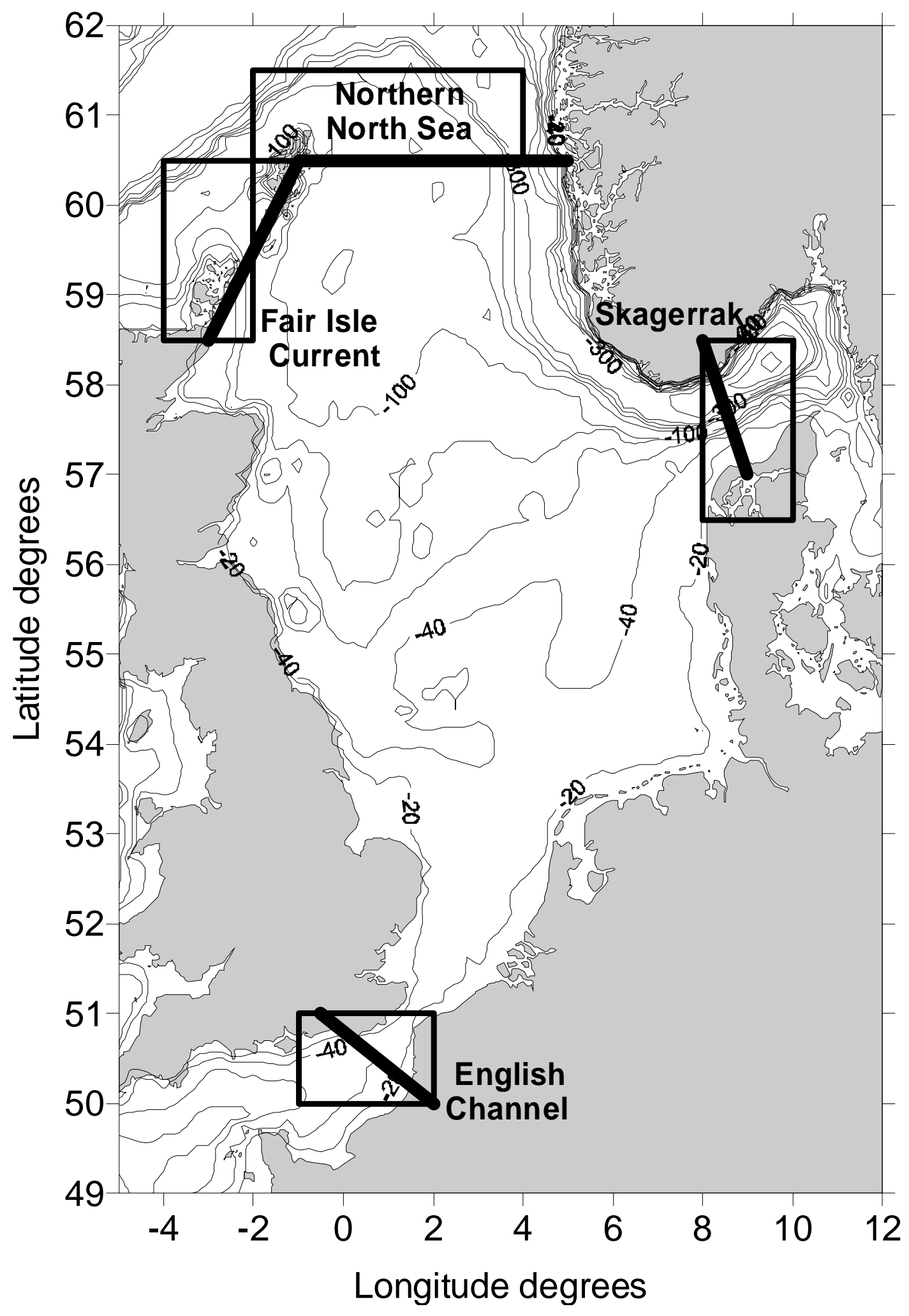



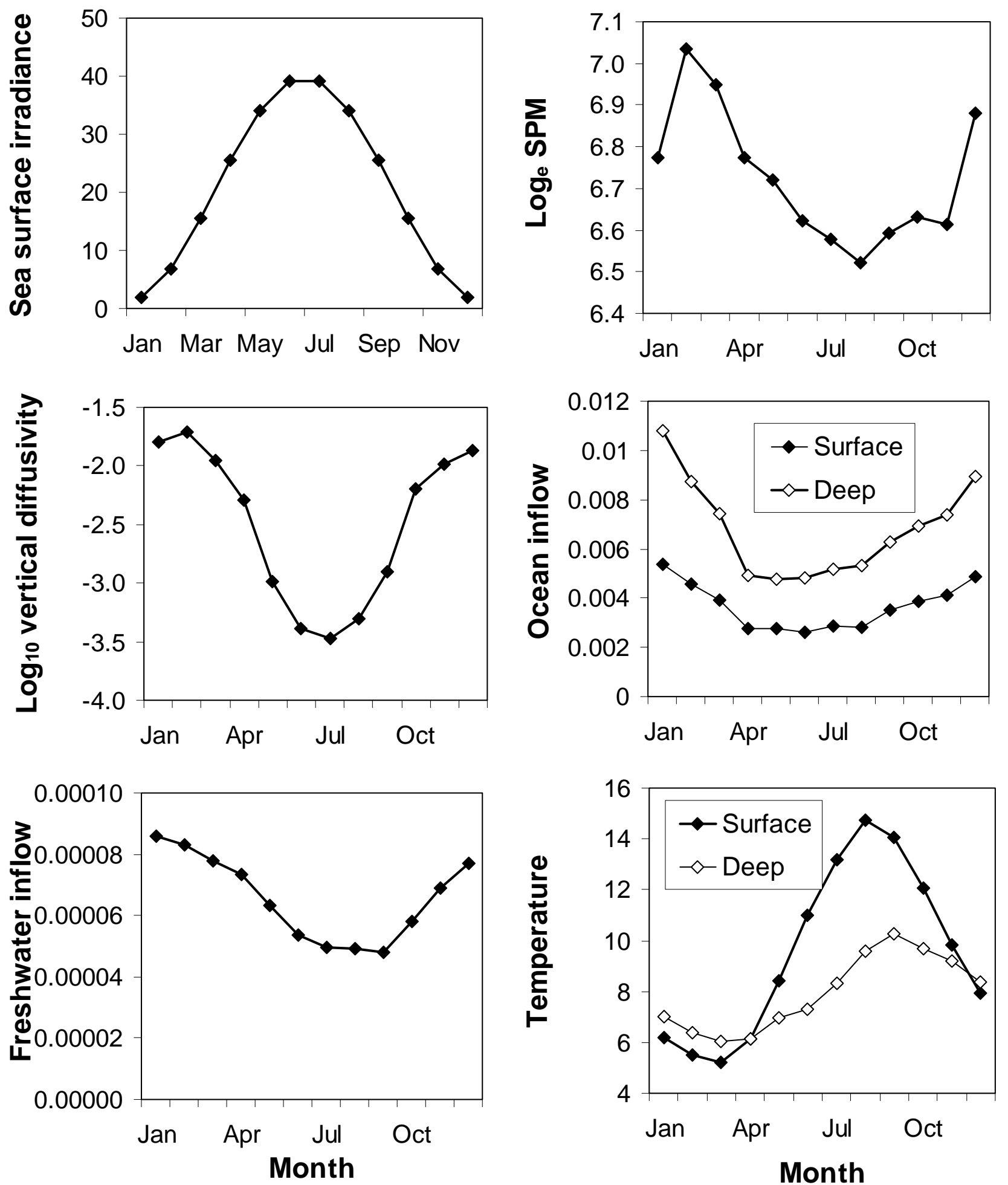

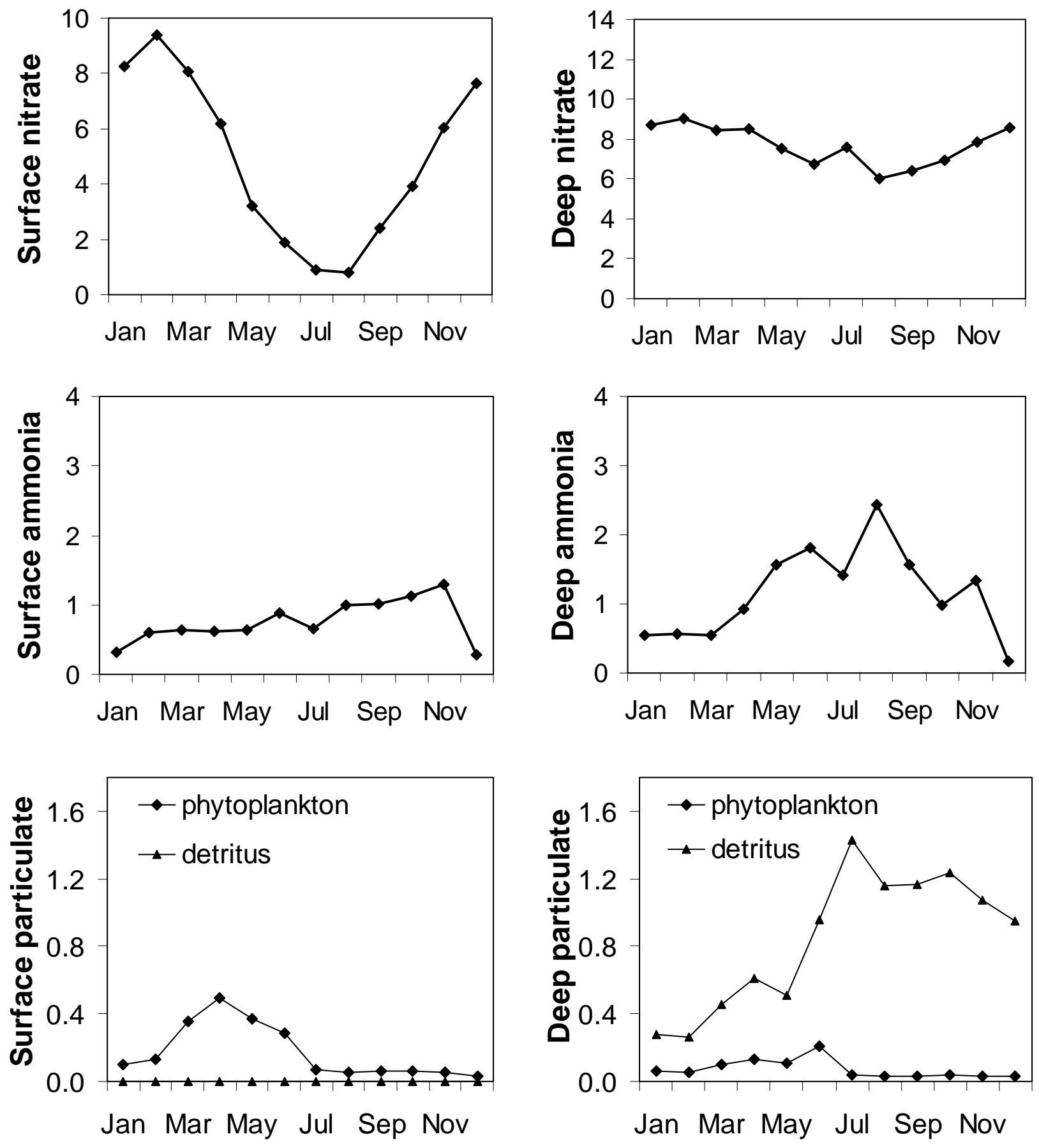

Month Month 

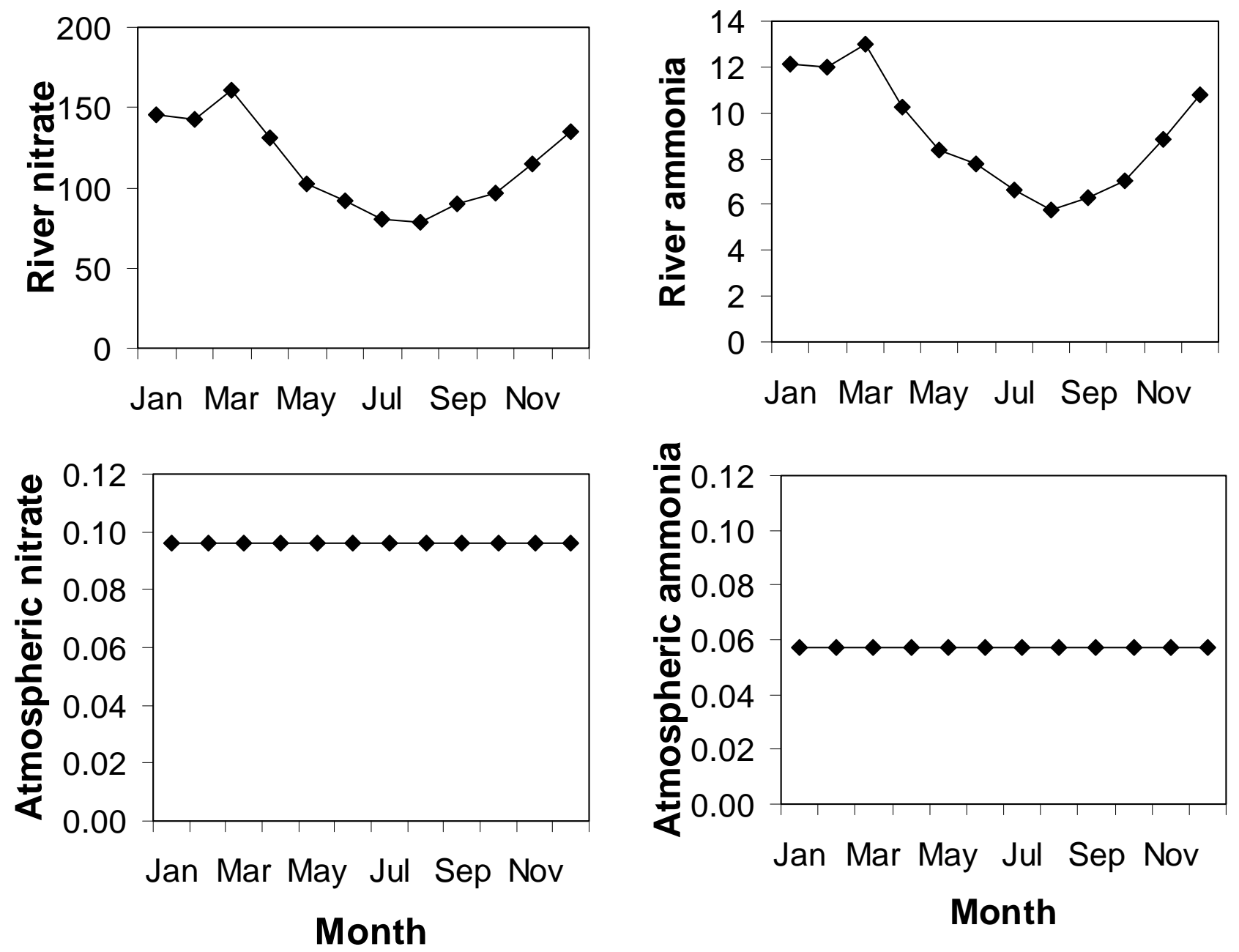

Month 


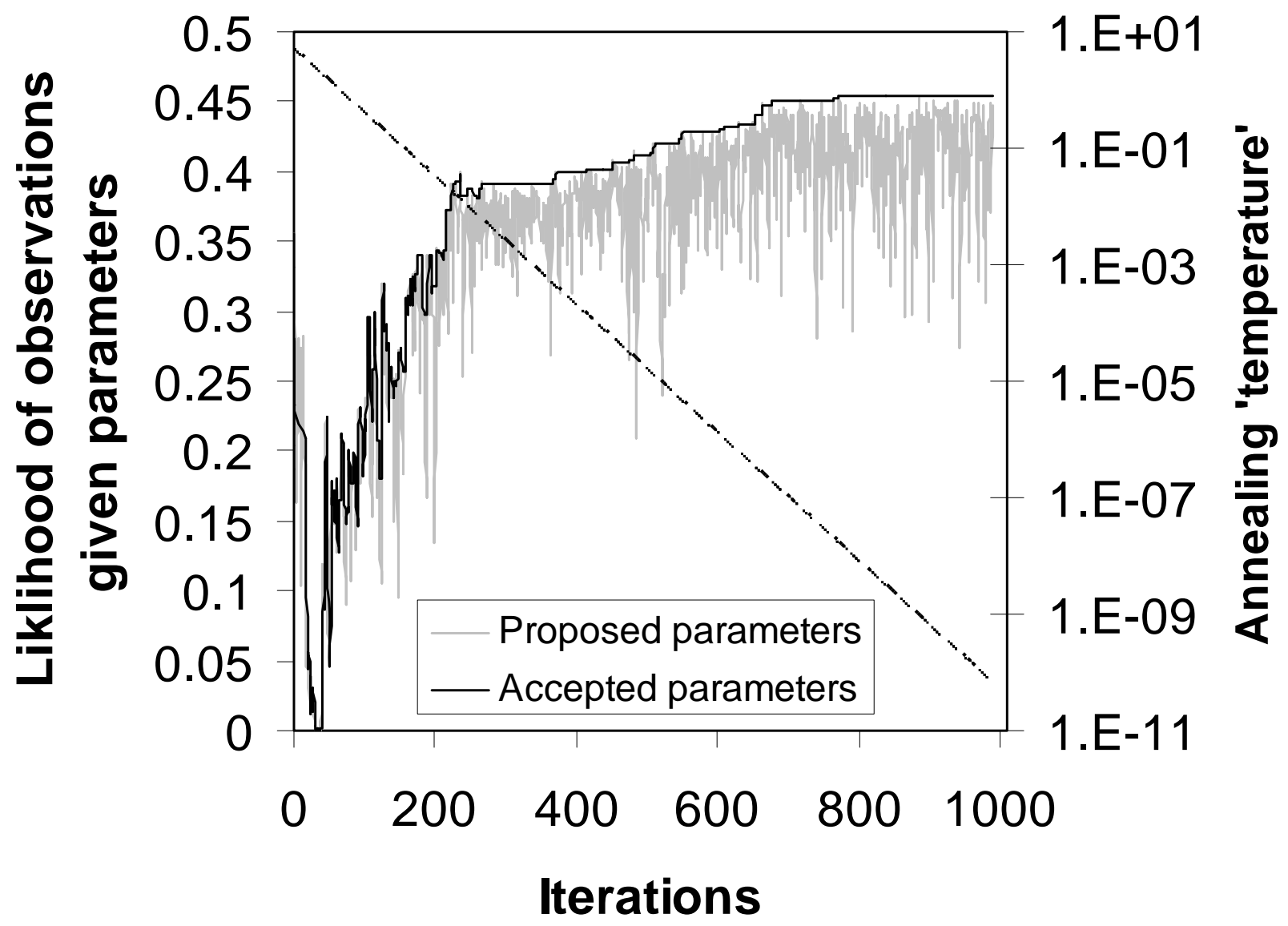




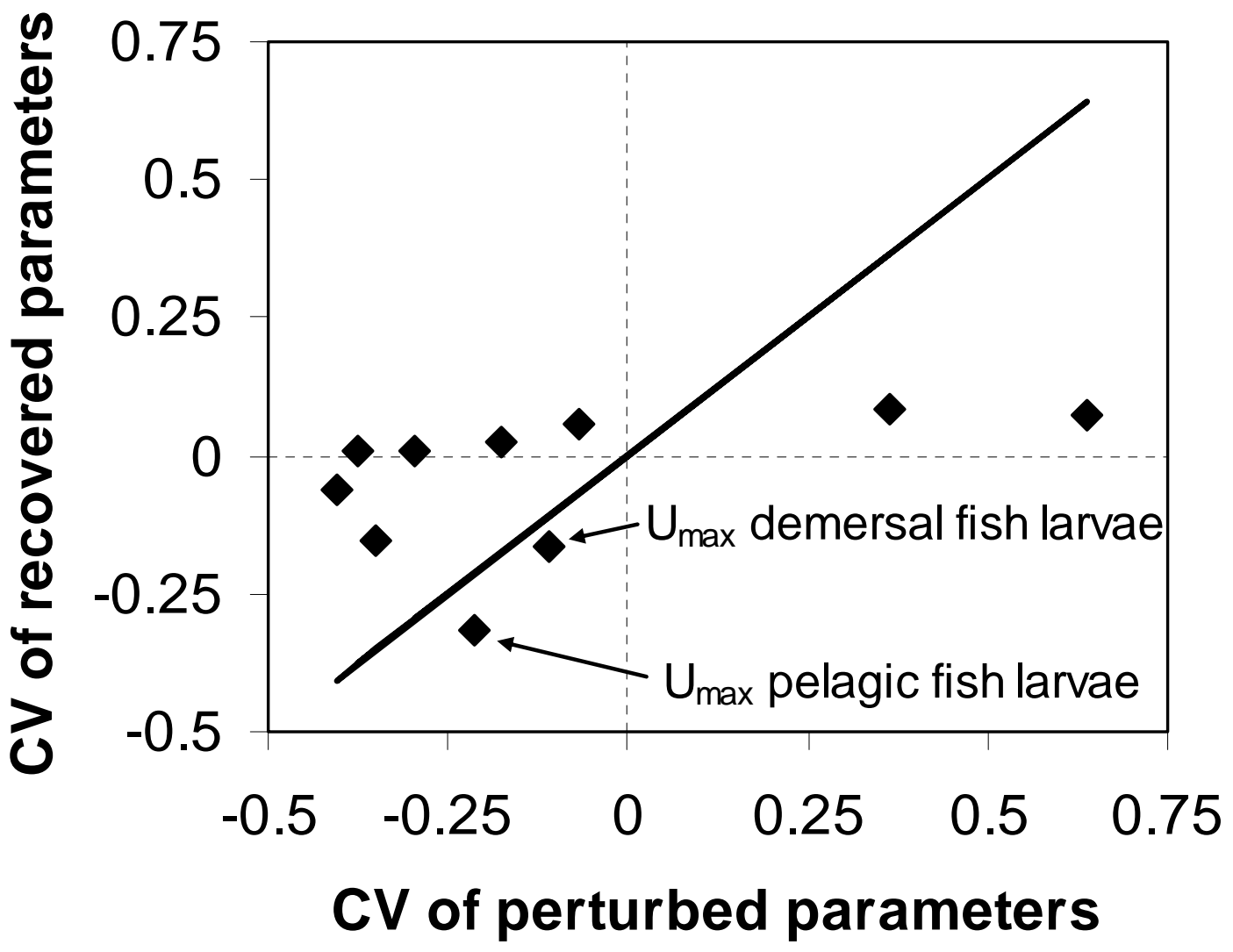


Figure ${ }^{9}$

?

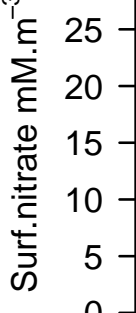

$10-\prod_{1}^{1}$

$5-$

Jan Apr Jun Sep Dec

(

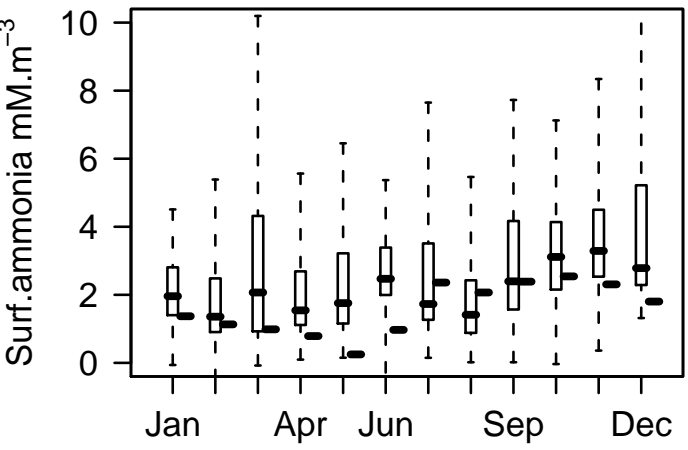

\begin{tabular}{c}
$?$ \\
\hline \\
\hline \\
\hline \\
\hline
\end{tabular}

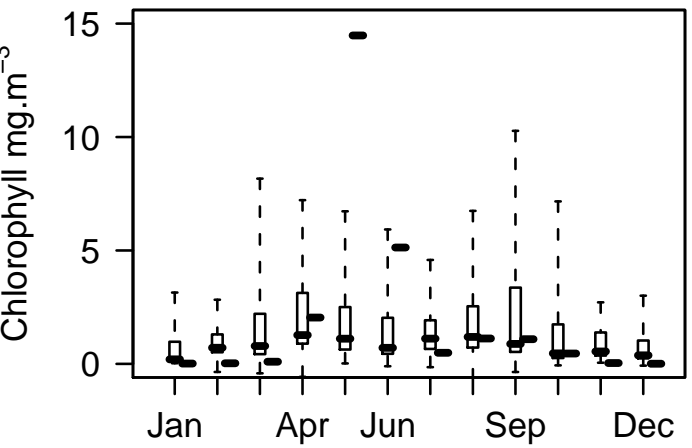

(1)

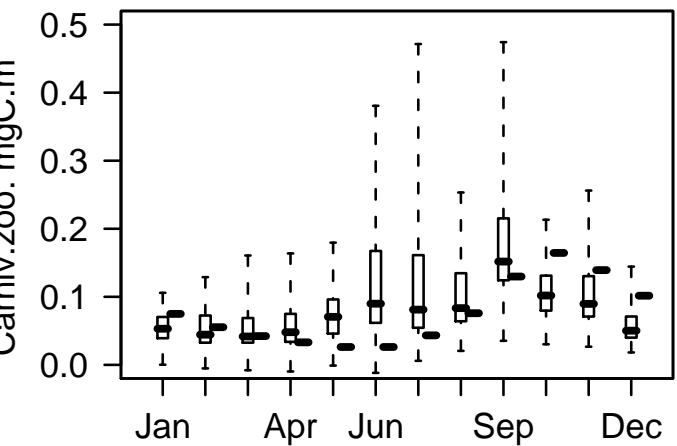

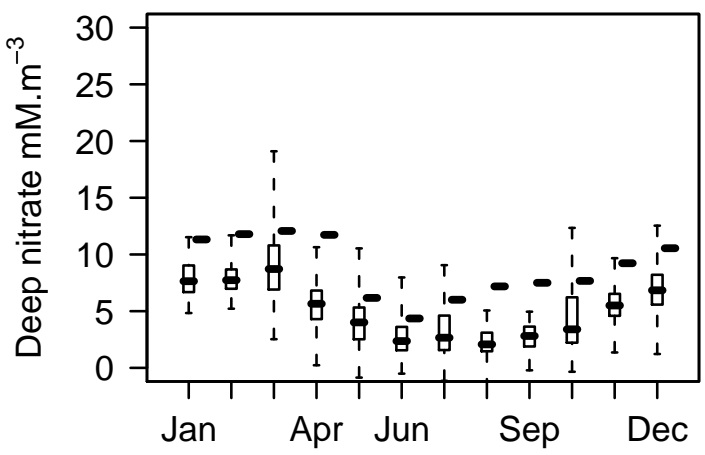
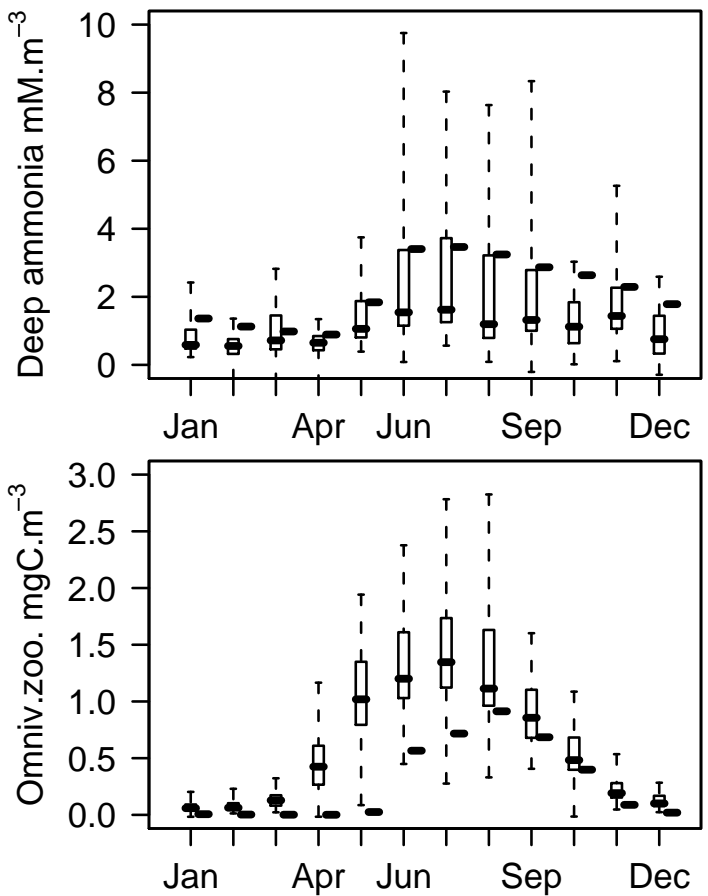


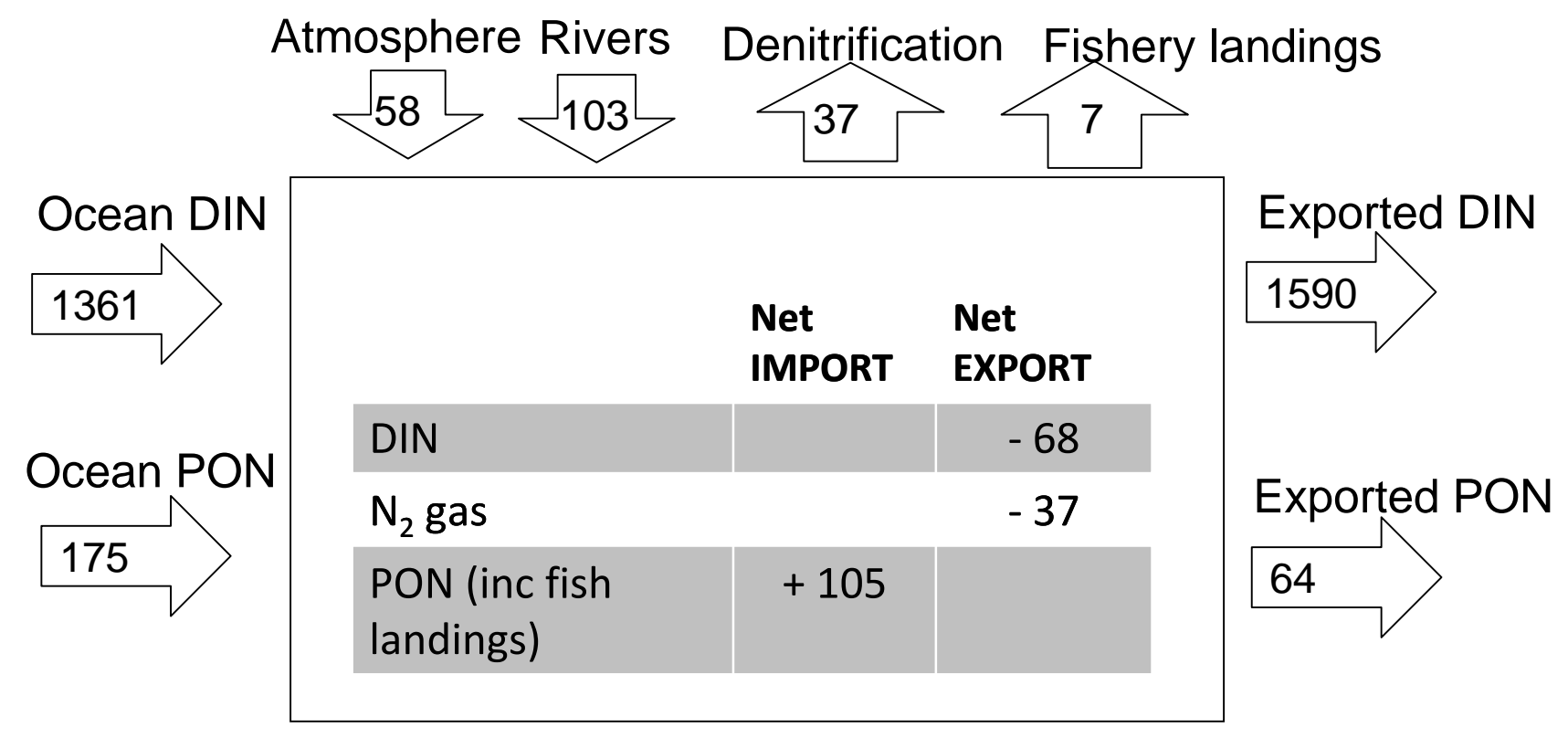




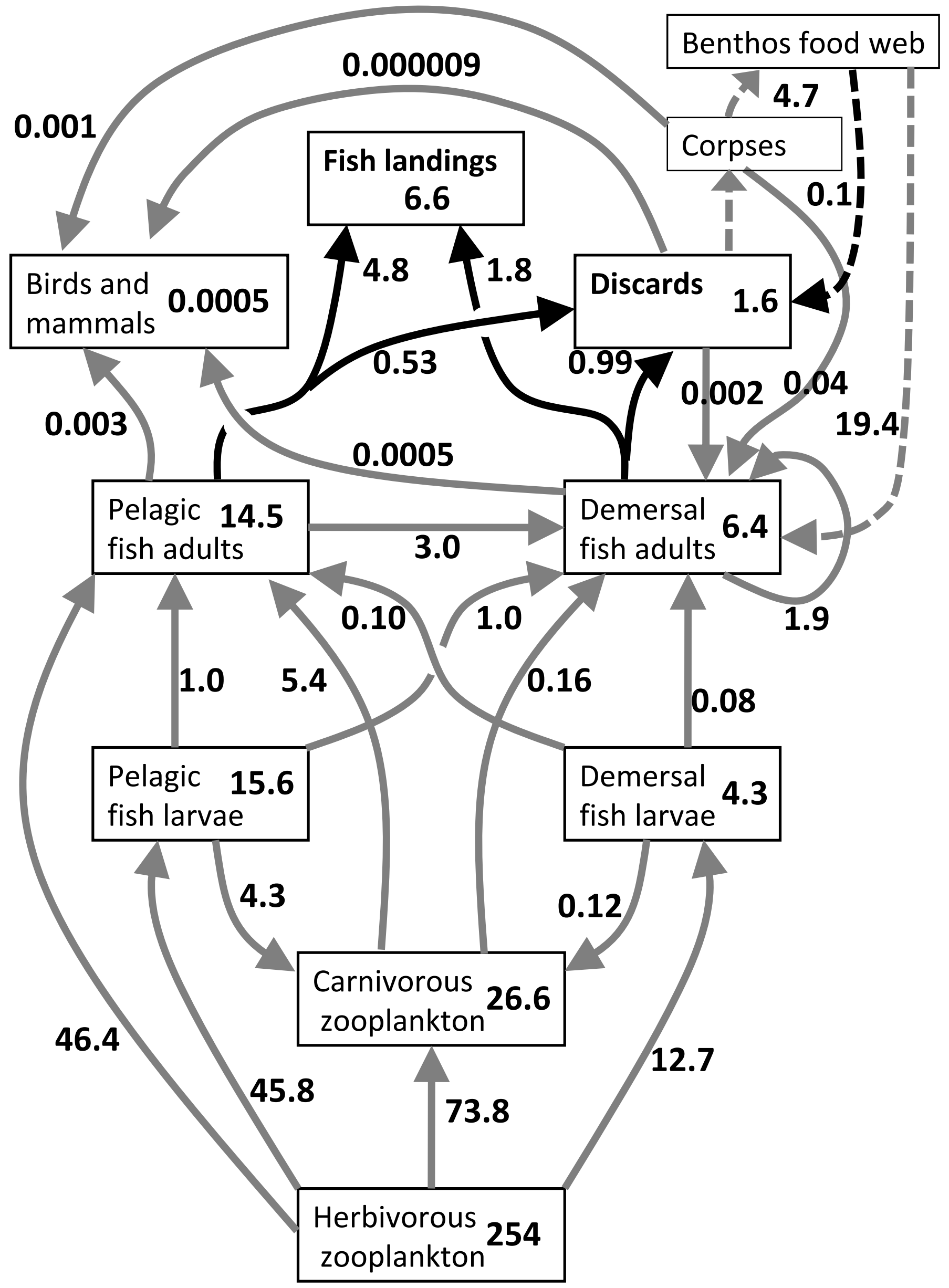




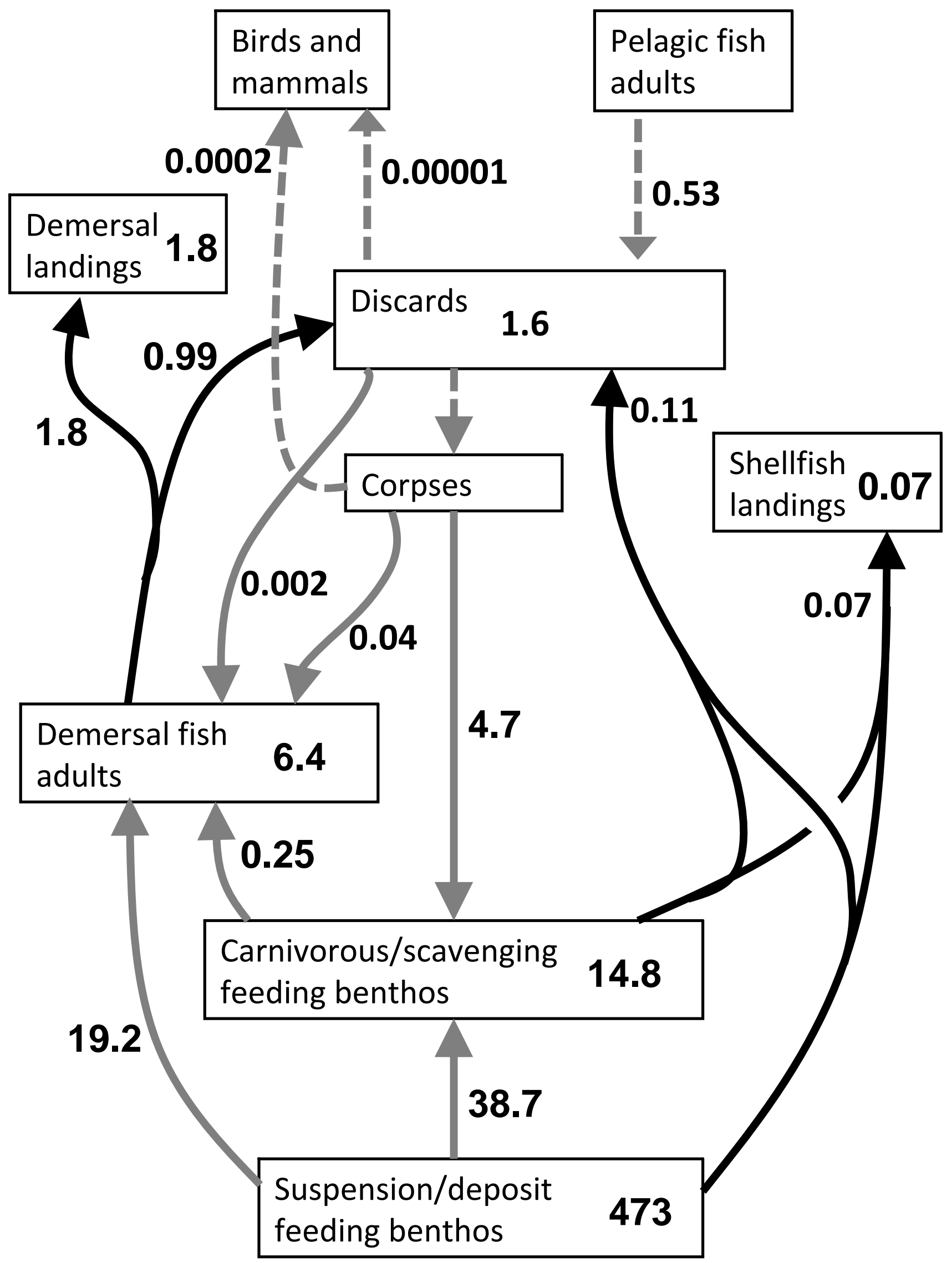


Figure 14 Demersal fish production
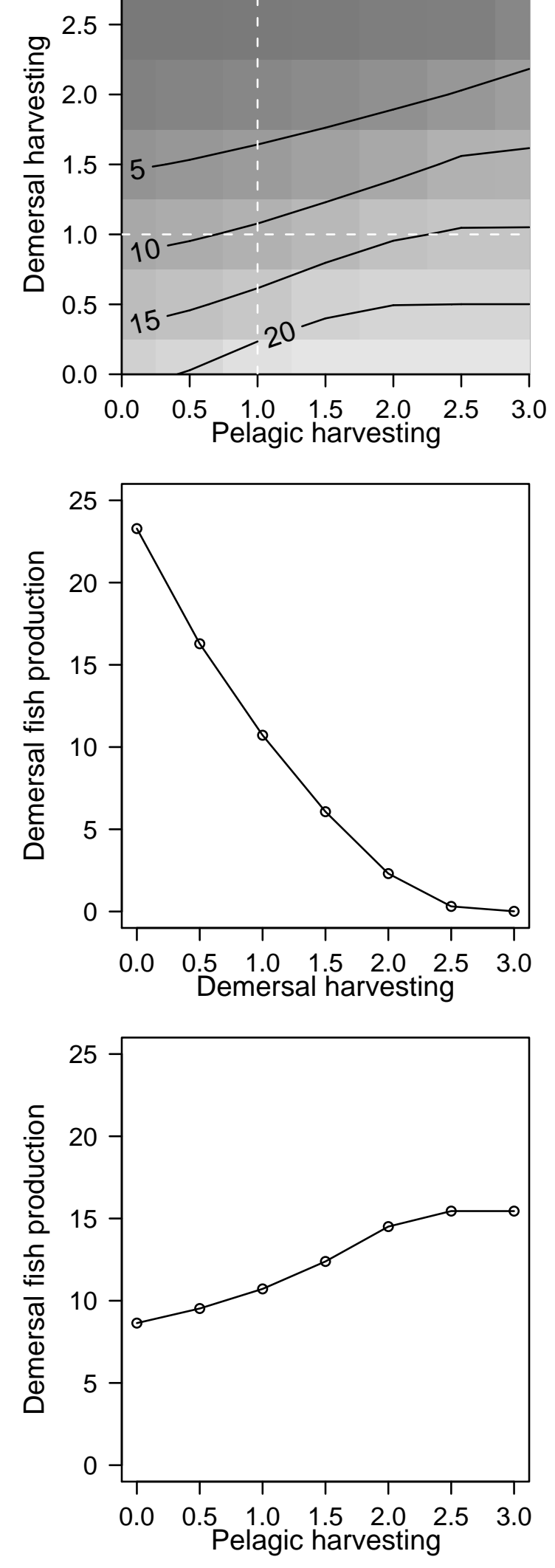
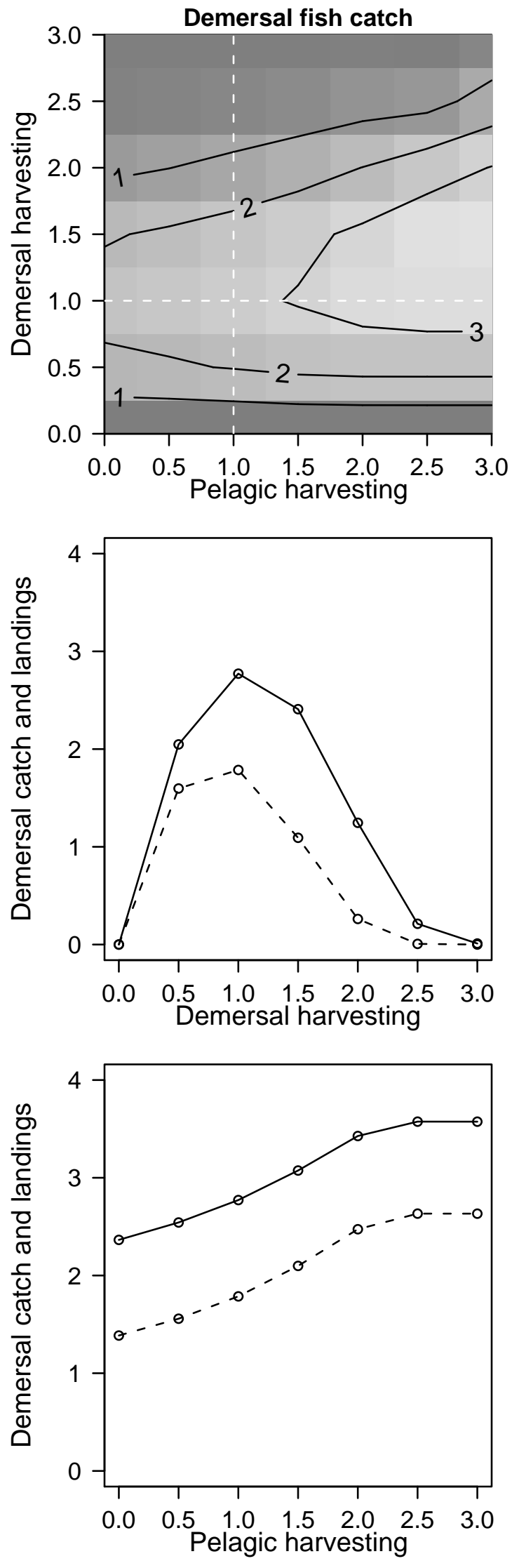
Figure 15
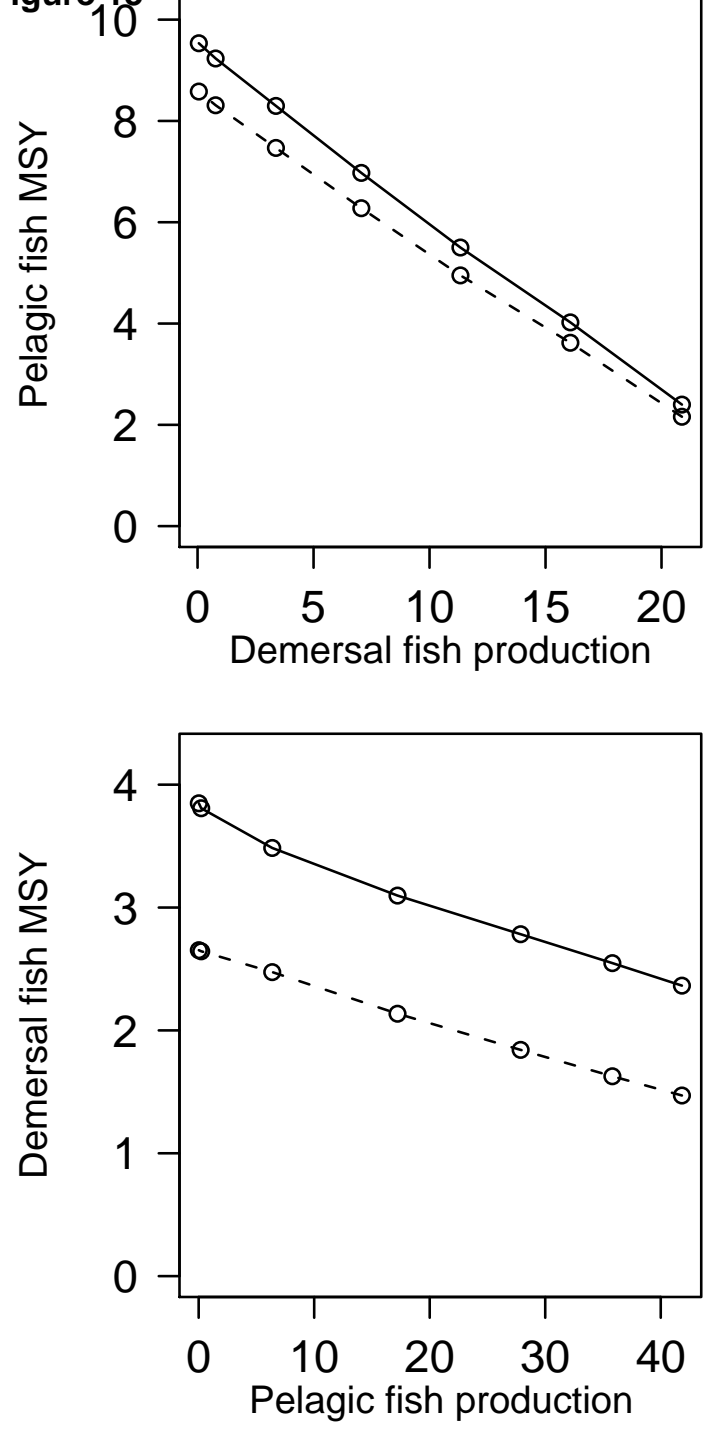
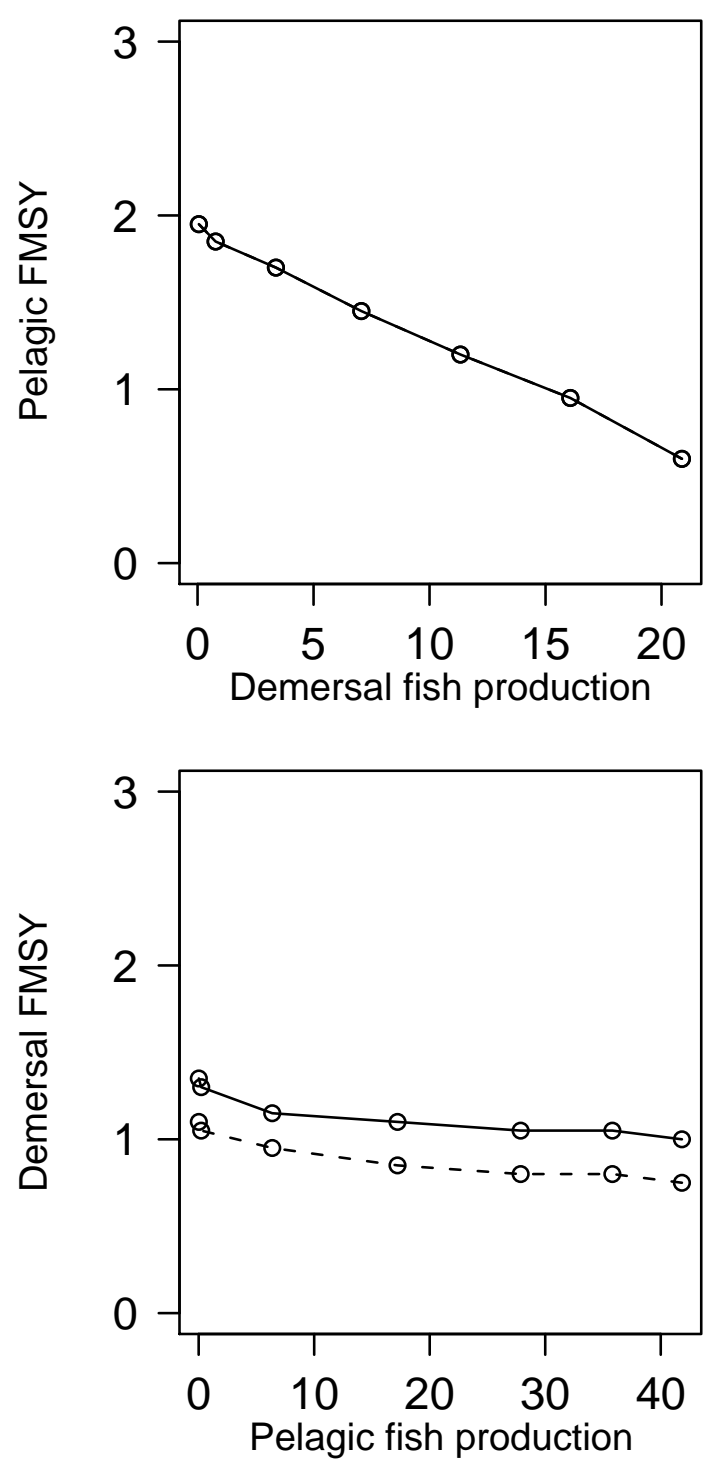
Figure 16

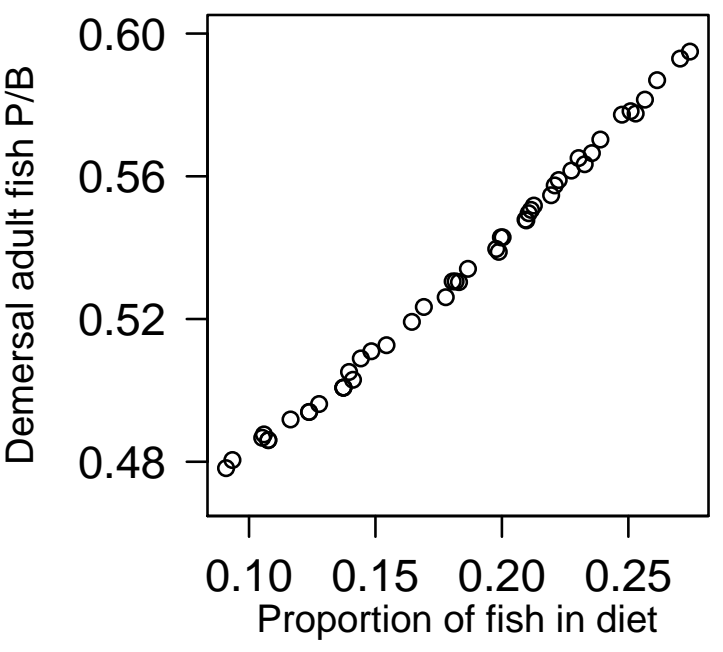

Proportion of fish in the diet

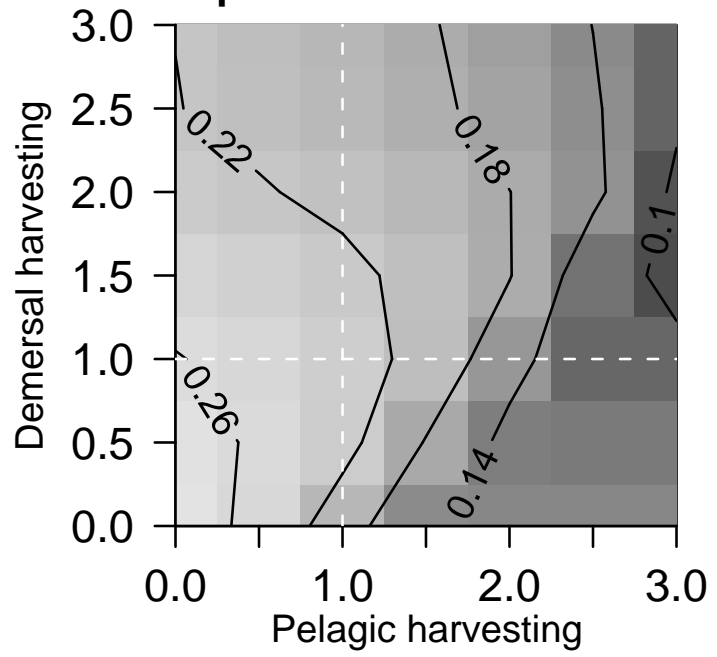



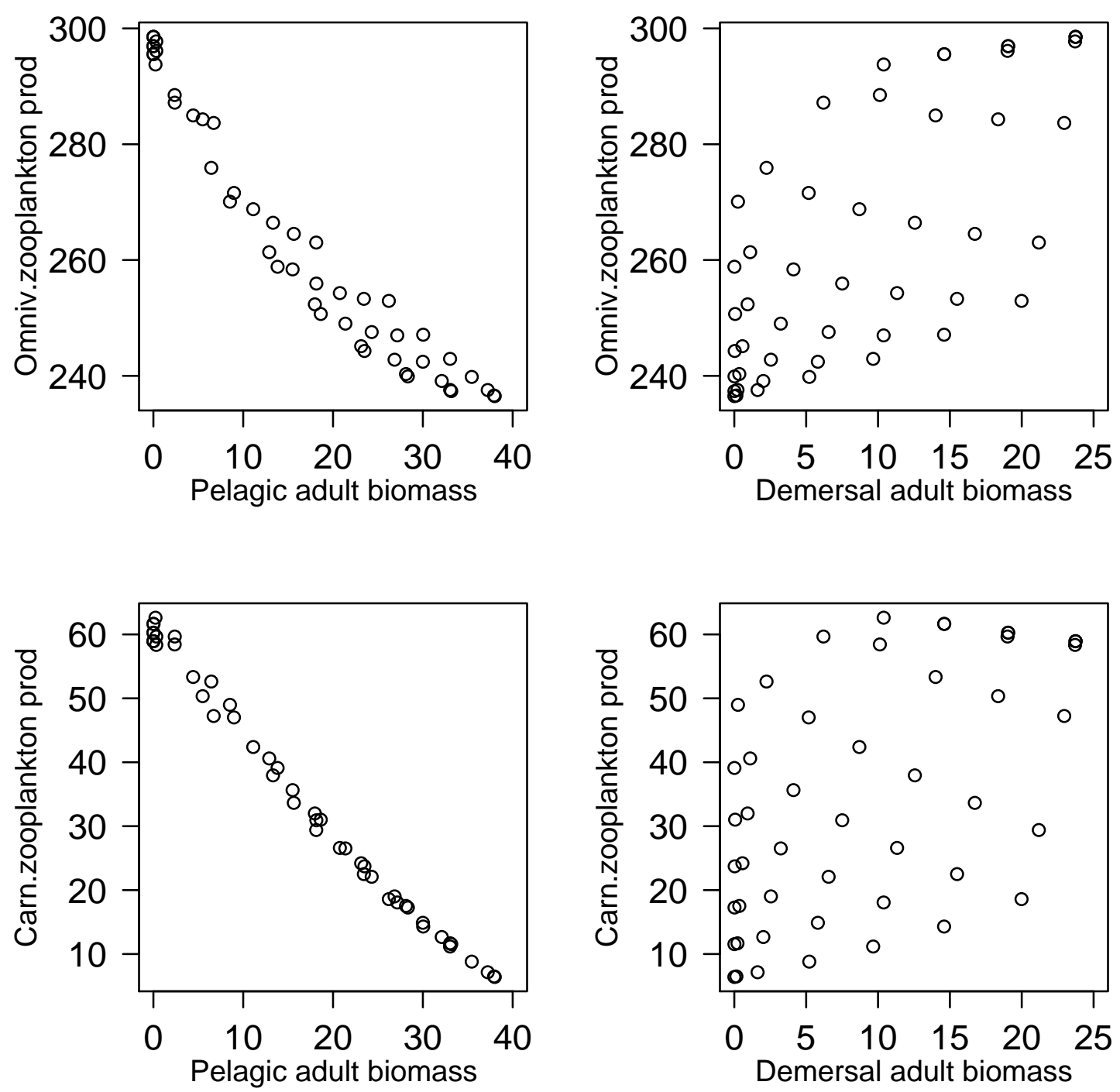

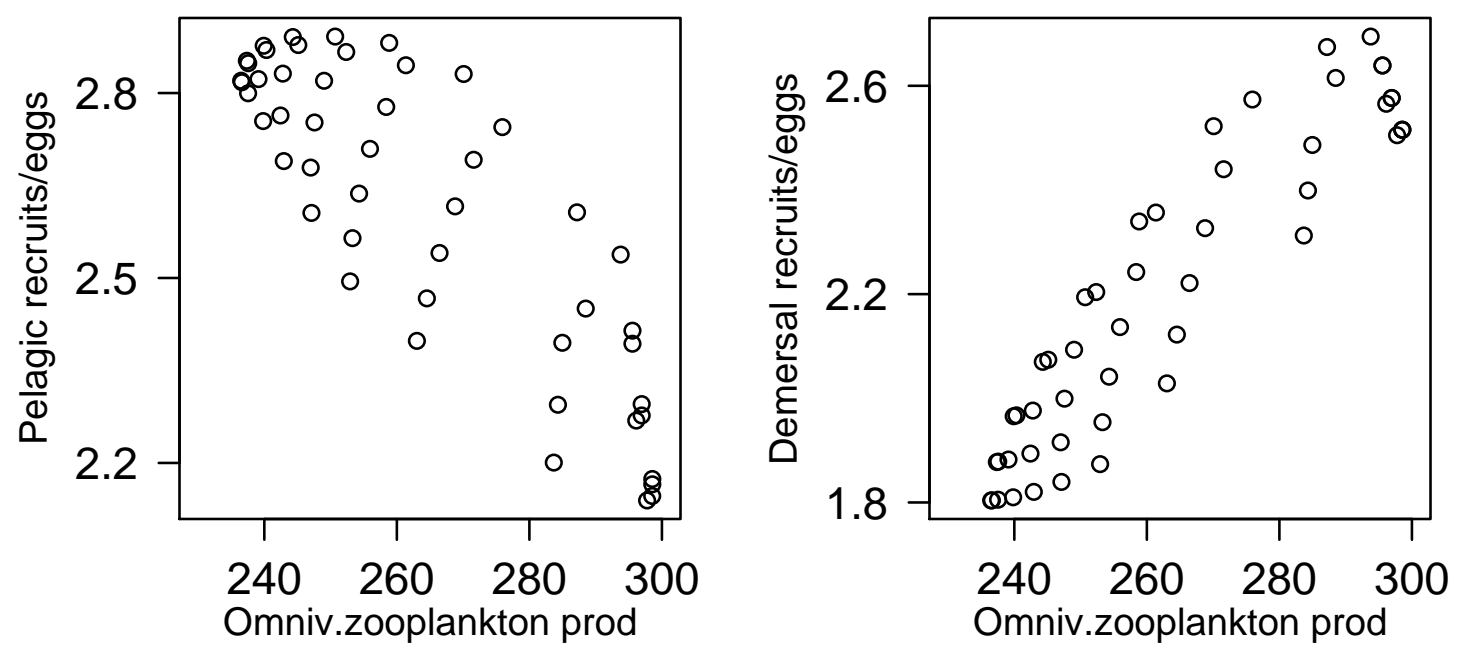


\section{Shellfish landings}

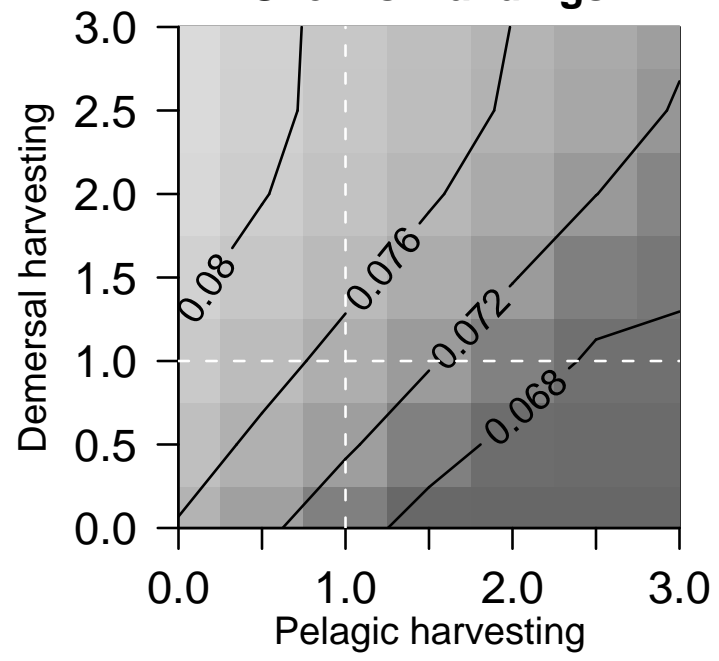

Benthos discards

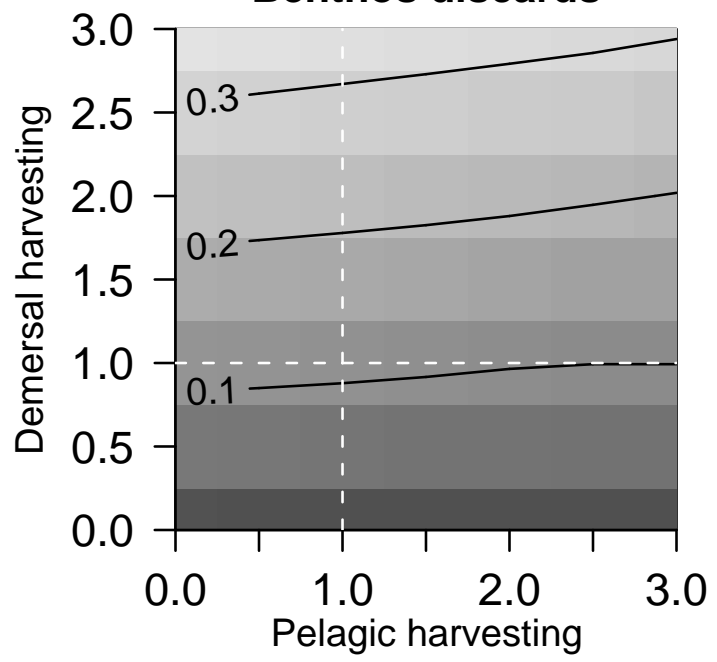


Figure ${ }^{21}$ Susp/det.benthos production

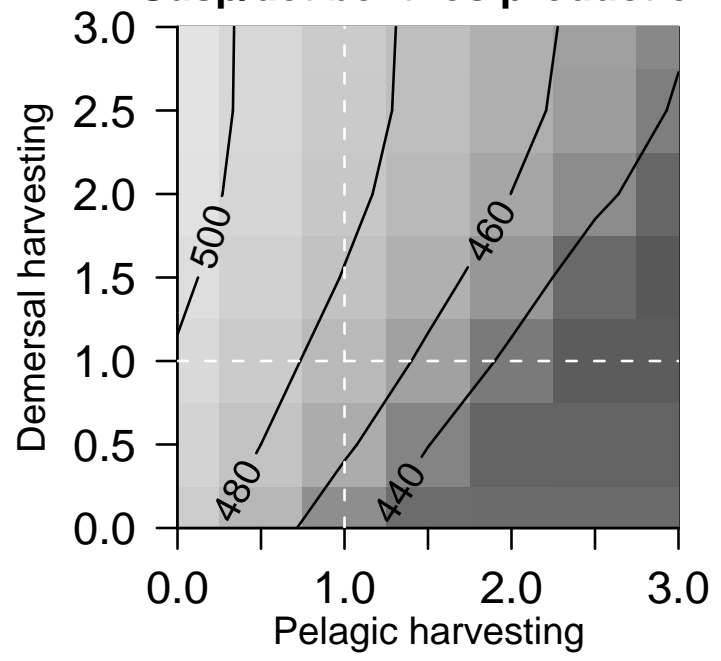

Susp/det.benthos M/B

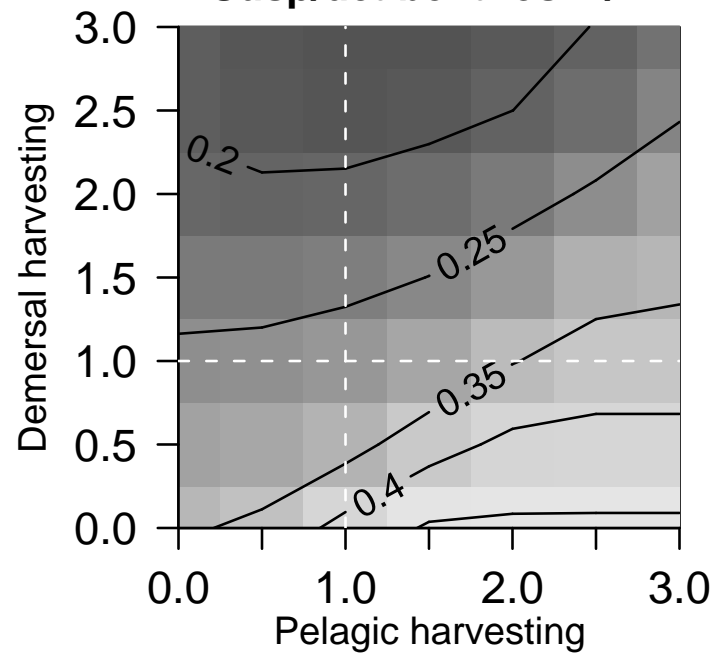

Susp/det.benthos P/B
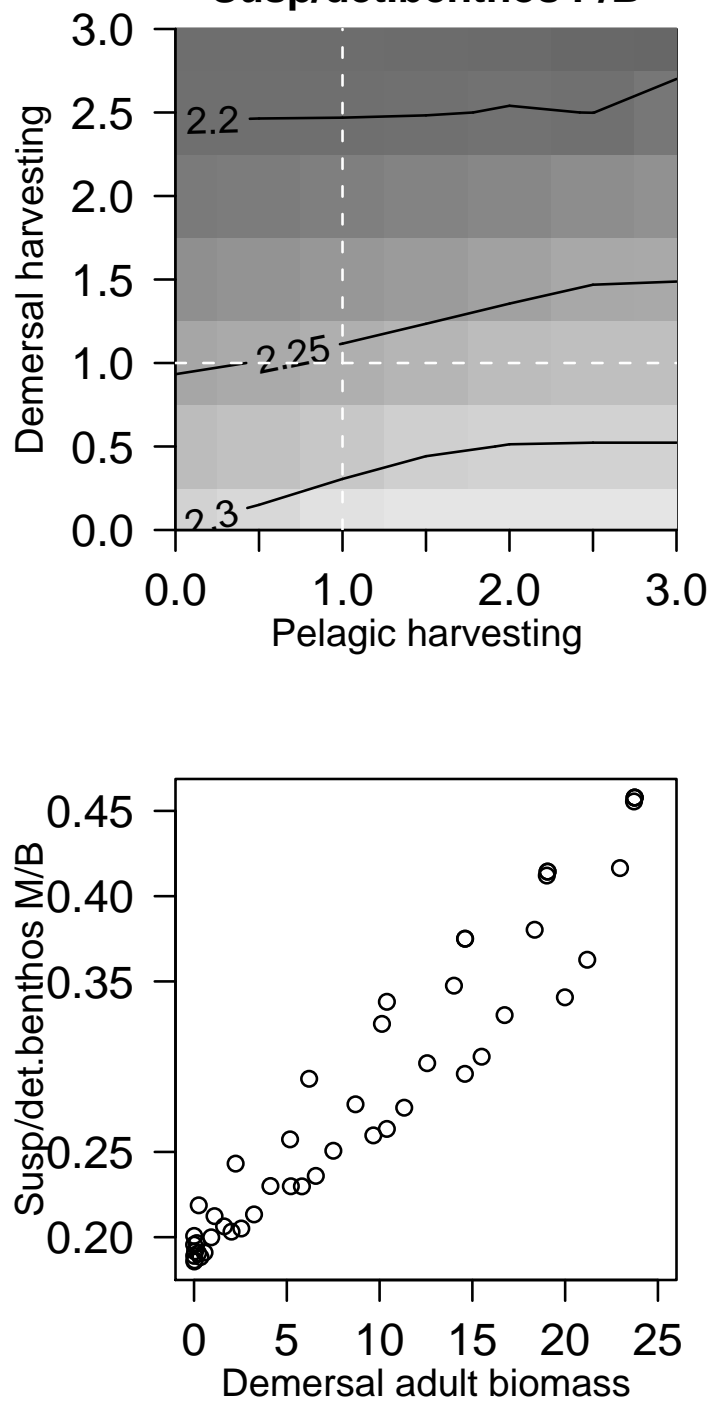
Figure 22 Carn.benthos production

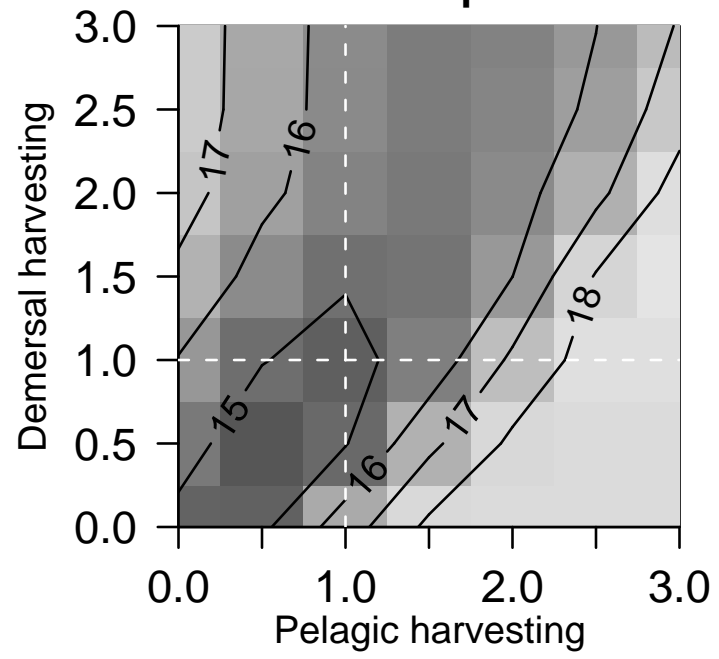

Carn.benthos M/B

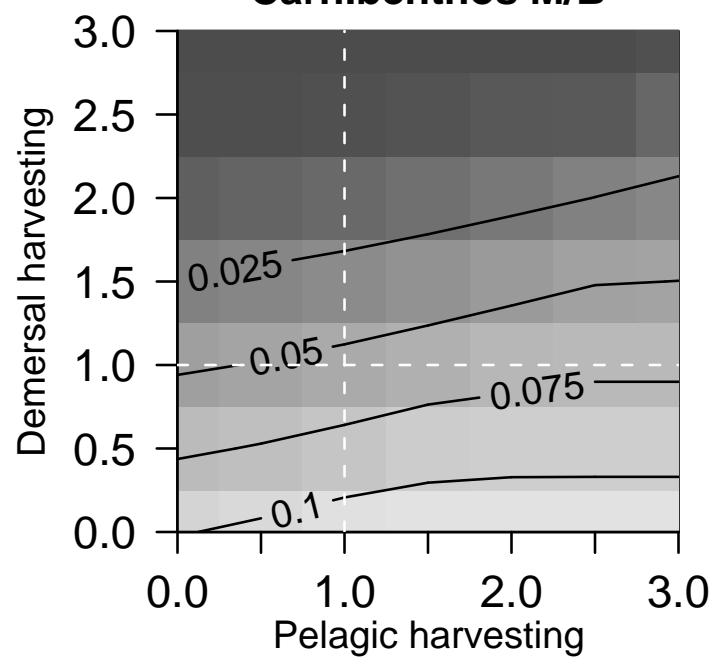

Carn.benthos P/B

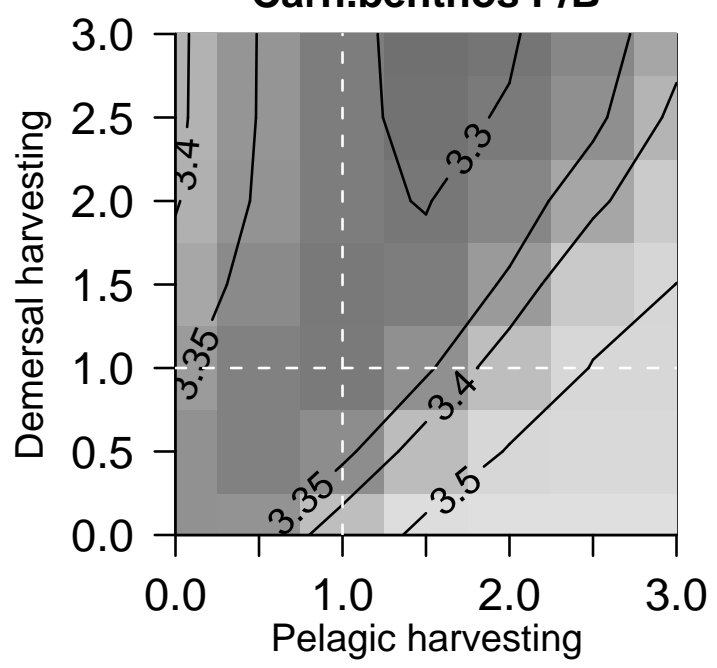

Corpse biomass

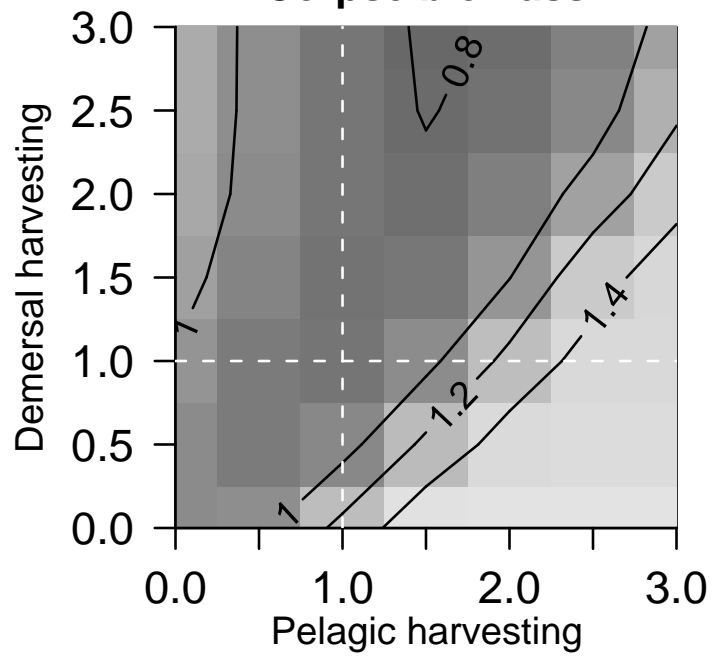


Figure 23 Bird/mammal food cons.

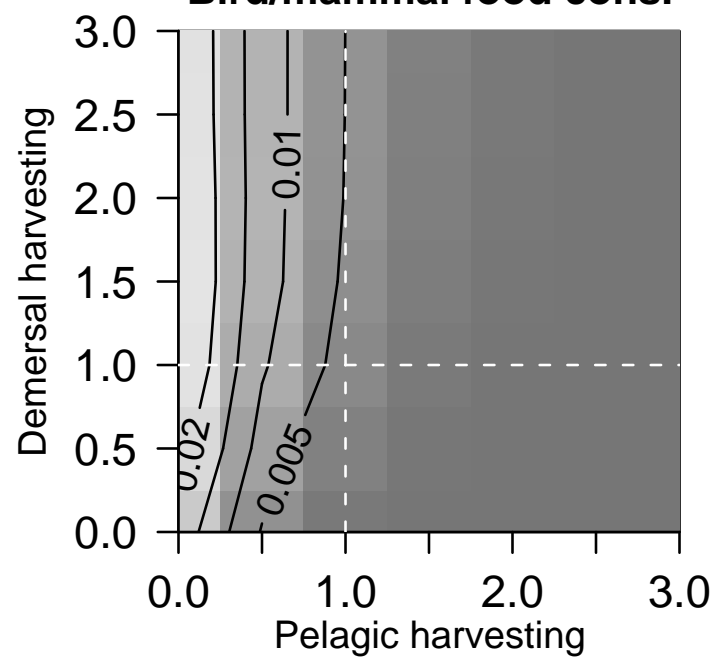

Prop. demersal fish

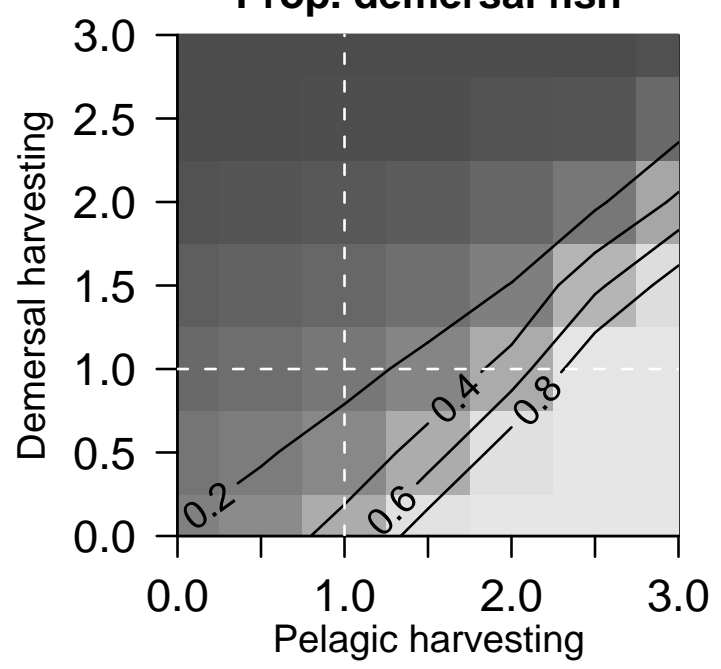

Prop. pelagic fish

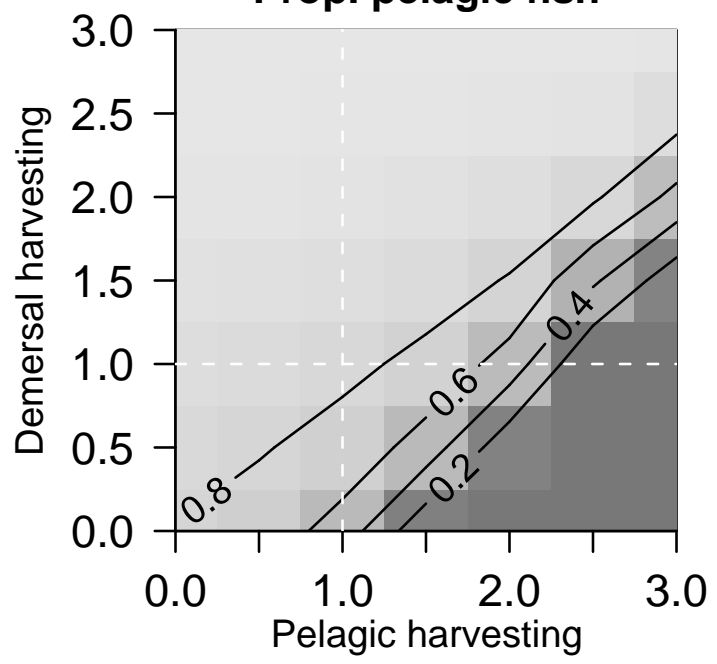

Prop. carrion

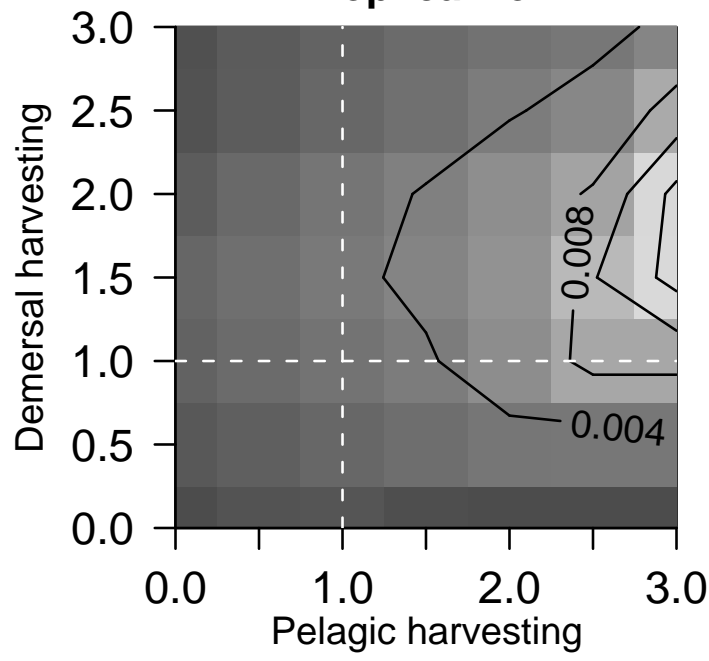



Supplementary Material - model description
Click here to download e-component: REVISE

Click here to download e-component: REVISED-CAMEO-PIO-paper-SUPPLEMENTARY-MATERIAL_24-02-2012.pdf

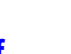
res 


\title{
PROGRESS IN OCEANOGRAPHY, CAMEO SPECIAL ISSUE
}

\section{Ecosystem limits to food web fluxes and fisheries yields in the North Sea simulated with an end-to-end food web model.}

\author{
Michael R Heath \\ University of Strathclyde, Marine Population Modelling Group, Department of \\ Mathematics and Statistics, Livingstone Tower, Glasgow, G1 1XP, UK \\ e-mail: m.heath@strath.ac.uk \\ Tel: $+44(0) 1415483591$ \\ Fax: $+44(0) 1415483345$
}

SUPPLEMENTARY MATERIAL

Technical description of the ecosystem model.

\section{Physical structure}

The model resolved 2 water column layers, and an underlying sediment layer in the vertical plane, because seasonal vertical layering has a defining influence on the food web fluxes of shelf seas (Tett, 1981). Fluxes of material across the internal interface between the water column layers were represented as being due to sinking, vertical advection and mixing, and also implicitly due to the activity of vertically migrating grazers. Vertical exchanges of dissolved inorganic components between the sediment layer and the overlying water layer were represented as a diffusive process, whilst the flux of particulate matter between the sediment and overlying water was due to sinking, predation on benthos by water-column living fauna, and filter-feeding by benthos.

\section{The state variables}

\subsection{Primary producers}

Phytoplankton were represented by a single guild which utilized both nitrate and ammonia but with different preferences. Nutrient uptake by phytoplankton guilds was constrained to the surface layer and formulated to depend on depth mean daily irradiance, and the mass of phytoplankton was subject to vertical exchange between layers by sinking, advection and mixing. Losses of phytoplankton were due to advection out of the model, predation by zooplankton, and a density-independent lysis rate. Phytoplankton biomass lost due to lysis was transferred to the suspended detritus state variable.

\subsection{Zooplankton}

Two guilds of zooplankton were represented. Herbivorous zooplankton (conceptually taxa ranging from micro-zooplankton to copepods) fed on phytoplankton and 
suspended detritus. Carnivorous zooplankton (conceptually large predatory crustaceans and soft-bodied invertebrate predators) fed on herbivorous zooplankton and larval fish.

Both zooplankton guilds were represented as depth integrated populations, implying that their active migration behaviour outweighed any vertical exchanges due to physical advection and mixing. Herbivorous zooplankton distributed their feeding activity between the surface and deep layers in proportion to the vertical distribution of their prey. Both herbivorous and carnivorous zooplankton excreted to the surface and deep layer ammonia pools in proportion to layer thicknesses, but defecated material was transferred directly to the deep water detritus layer, reflecting the rapid sinking rate of zooplankton faecal particles.

\subsection{Benthos}

Benthic fauna were resolved into suspension/deposit feeding, and carnivorous/scavenge feeding guilds. The suspension/deposit feeders consumed suspended detritus and phytoplankton from that part of the water column assigned for them to filter, and sedimentary detritus. The carnivorous/scavenge guild fed on suspension/deposit feeders and the corpses of other guilds produced by densitydependent mortality (see later). In the model, both benthos guilds defecated detritus to the sediment layer and excreted ammonia to the deep layer of the water column. Both the suspension/deposit feeding and carnivorous/scavenge benthos guilds were potentially subject to harvesting by fishing.

\subsection{Fish}

Fish were resolved into pelagic and demersal guilds. Each guild had an internal demographic structure represented by an early life history stage (eggs and larvae), which for convenience is hereafter referred to here as "larvae", and a postlarval/mature stage which is referred to here as "adults". Adults were potentially subject to harvesting by fishing whilst larvae were not. Within a set interval of days each year, adult fish shed a percentage of their biomass per day which was transferred directly to larvae as a representation of spawning. Within a different set interval of days each year, a percentage of the biomass of larvae per day recruited to the adults.

Fish larvae (of both pelagic and demersal fish) fed on herbivorous zooplankton, and were preyed upon by carnivorous zooplankton and the adults of pelagic and demersal fish. Adult pelagic fish fed on herbivorous and carnivorous zooplankton, and larval fish. Adult demersal fish fed on carnivorous zooplankton, but not herbivorous zooplankton, all types of benthos, adult and larval fish, fishery discards and corpses (see later). Adult pelagic and demersal fish were preyed on by the top predator guild in the model.

Demersal fish excreted ammonia and defecated detritus only to the deep water column layer, whilst pelagic fish and all larval fish excreted to the surface layer and defecated to the deep water column layer.

\subsection{Top predators}

The top predators in the model were conceived as birds and mammals, and represented by a single demographically unstructured guild. The top-predator guild fed on adult pelagic and demersal fish, discards from the fisheries (see later), and 
corpses. Top predators excreted to the surface layer and defecated detritus to the deep layer.

\subsection{Detritus and dissolved inorganic components}

The model resolved ammonia and nitrate concentrations in the water column and sediment pore water layers, and various forms of organic detritus. Transformations between detritus and inorganic nitrogen in the real world are due to bacterial activity, but the model did not resolve the biomass of bacteria explicitly. To do so effectively, would require representation of, at least, carbon and oxygen dynamics in order to meaningfully articulate bacterial dynamics. The activities of bacteria with respect to nitrogen were therefore represented by three rates of exchange between the non-living components; 1) mineralization of detritus to ammonia, 2) nitrification of ammonia to nitrate, and 3) denitrification of nitrate to nitrogen gas. Denitrification was effectively a sink term for nitrogen in the model since there was no return process of nitrogen fixation.

Suspended detritus in the surface and deep layers originated from the defecation of zooplankton, fish and top predators, and the lysis of phytoplankton cells. Suspended detritus had a sinking rate expressed as a proportion per day transferring from the surface to deep layer, and from the deep layer to the sediment, and was also exchanged vertically by mixing and advection. For settlement from the deep layer to the sediment the proportion per day was also inversely related to the vertical mixing rate so that a smaller proportion settled to the sediment in more strongly mixed systems, as a caricature of the re-suspension of sediment in regions of strong tidal flow or during meteorological mixing events.

Detritus in the water column was consumed by bacterial mineralization and converted to ammonia, and grazed by herbivorous zooplankton. In the deep layer, suspension/deposit feeding benthos could also feed on suspended detritus in a layer of a given thickness above the seabed. Detritus was assumed to be uniformly distributed through the deep layer, so only a fraction of the deep layer suspended detritus was available to the benthos.

Sediment detritus was also consumed by the suspension/deposit feeding benthos guild, and mineralised by bacteria to ammonia. Ammonia produced in the seabed by mineralization and nitrate produced by nitrification of ammonia, contributed to dissolved pools in the pore-water layer. Exchange of ammonia and nitrate between the sediment pore-waters and the deep water column layer was then governed by the sediment-water diffusion coefficient acting on the concentration gradient across the interface.

Additional forms of detritus were included in the model to represent the corpses of the larger taxa in the food web (carnivorous benthos and plankton, fish, and birds/mammals). Fishery discards (see later) formed a food resource in the water column for birds/mammals and demersal fish, and were transformed at a fixed proportion per day to corpses. Corpses were also produced as a result of densitydependent mortality, and were consumed by carnivorous benthos, adult demersal fish and birds/mammals, and a temperature dependent proportion of their mass per day was converted to sediment detritus.

\section{Biological rate processes}

\subsection{Bio-geochemical rates}


Rates of mineralization, nitrification and denitrification were defined by proportions of substrate consumed per day. Temperature has a profound effect on bacterial processes, so these rate parameters were temperature dependent according to a $\mathrm{Q}_{10}$ relationship (see later).

\subsection{Grazer uptake rates}

The mass flux from prey to predator per unit time $\left(\Omega, \mathrm{mMN} \mathrm{m}^{-2} \mathrm{~d}^{-1}\right)$ was given by a Michaelis-Menten relation.:

$$
\Omega=\frac{\text { predator } \cdot \text { prey } \cdot \text { pref } f_{\text {prey-predator }} \cdot U_{\max (\text { predator })}}{\text { prey }+\left(h_{\text {predator }} \cdot\left(T_{l}\right)\right)}
$$

The term prey referred to the abundance $\left(\mathrm{mMN} \mathrm{m}^{-2}\right)$ of a given prey guild in a depth layer of thickness $\mathrm{T}_{1}$, whilst predator referred to the abundance $\left(\mathrm{mMN} \mathrm{m}^{-2}\right)$ of a predator guild. The half-saturation concentration $\mathrm{h}_{\text {predator }}\left(\mathrm{mMN} \mathrm{m}^{-3}\right)$ was considered to be independent of temperature, and the same for all prey of a given predator. The term $U_{\max \text { (predator) }}\left(\mathrm{mMN} . \mathrm{mMN}^{-1} \cdot \mathrm{d}^{-1}\right)$ represented the maximum uptake rate of all prey classes combined by the predator guild, and was assumed be dependent on sea temperature according to a $\mathrm{Q}_{10}$ function for all predators except birds/mammals.

The relative contributions of prey classes to uptake by a predator guild was set

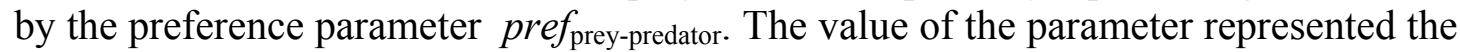
proportion of total uptake if all prey classes were present at equal concentration. Hence the sum of all prey preferences for a given predator was always unity. Note that this differs from formulations for representing weight-specific uptakes of multiple prey types by predators at a species level. When multiple prey classes are available to a species the effective concentration of prey against which the degree of saturation is judged, is the sum over all prey classes, with a preference term to scale the electivity of the predator of each prey class. Hence, a super-abundance of one prey class inhibits the uptake of others, for example:

$$
\frac{\Omega}{\text { predator }}=\frac{\text { prey. } \text { pref }_{\text {preyr }} . U_{\max (\text { predator })}}{\sum\left(\text { prey.pref } f_{\text {prey }}\right)+h_{\text {predator }} .}
$$

In the model described here, however, the taxonomic range implicit in each guild was such that whilst a predator guild might rely on multiple prey guilds, there should be many species within the predator guild whose diets would not overlap. Hence, there was no a priori reason to suppose that uptake of one prey guild should markedly influence the uptake of others. For this reason, the uptake rates of different prey by a predator guild were represented as being independent and additive.

\subsection{Autotrophic uptake functions}

Primary production was represented by the light and concentration-dependent uptake rate of nutrient (nitrate or ammonia) by the phytoplankton guild $\left(\Omega, \mathrm{mMN} \cdot \mathrm{m}^{-2} \cdot \mathrm{d}^{-1}\right)$. Exactly as for the uptake of prey by predators, the mass of nutrient taken up per unit time was represented by a Michaelis-Menten relation with no interaction between nutrients (Dortch, 1990). However, in addition, nutrient uptake was scaled by the 
depth mean daily irradiance, such that uptake was zero at zero irradiance and increasing lineally to a maximum rate at a saturating value of daily depth mean irradiance $\left(\mathrm{L}_{\max }\right)$. Hence:

$$
\Omega=\operatorname{Min}\left\{1.0, \frac{L}{L_{\max }}\right\} \cdot \frac{\text { phytoplanlton } . \text { nutrient. } \text { pref } f_{\text {nutrient }- \text { phytoplanton }} \cdot U_{\max (\text { phytoplankon })}}{\text { nutrient }+\left(h_{\text {phytoplanton }} \cdot T_{l}\right)}
$$

As for the heterotrophic uptake processes, the parameter $U_{\max }\left(\mathrm{d}^{-1}\right)$ was assumed to be temperature dependent and the half-saturation term $\mathrm{h}_{\text {phytoplankton was }}$ assumed to be independent of nutrient type. There is ample support from analyses of field data on depth integrated carbon and nitrogen assimilation for expressing biomass-specific uptake by coarse functional group of phytoplankton in terms of linear functions of depth averaged irradiance (Platt et al., 1990; Forget et al., 2007; Lund-Hansen and Sorensen, 2009).

Autotrophic fixation of atmospheric nitrogen by cyanobacteria was disregard. In some ecosystems, direct nitrogen fixation can be a significant input to the nitrogen budget but the available evidence suggest that this is probably not important in the North Sea (Lipshultz and Owens, 1996).

\subsection{Metabolism}

Food ingested by heterotroph guilds was either assimilated or was passed to detritus and ammonia. The proportion assimilated was governed by a constant assimilation coefficient. Half of the non-assimilated food was assumed to be lost to detritus and half to ammonia. In addition to this feeding dependent ammonia excretion, all heterotroph guilds excreted a proportion of their biomass per day as ammonia, as a caricature of basal metabolism. The proportion excreted per day was assumed to be temperature dependent according to a $\mathrm{Q}_{10}$ function for all categories of heterotrophs except the top predators.

\subsection{Density dependent mortality}

Density-dependent mortality terms were included for carnivorous zooplankton, carnivorous/scavenge feeding benthos, larval and adult fish, and birds/mammals, and represented by quadratic functions defining a flux of biomass to corpses (flux of guild $\mathrm{j}$ to corpses $=\mathrm{z}_{\mathrm{j}} \mathrm{j}^{2}$ ). Hence the weight specific mortality rate increased linearly with guild biomass. Conceptually, the density-dependent mortality was regarded as a caricature of constraints on survival due to limitations of space (e.g. limited sheltering habitat for benthic fauna), or the attraction of predators to spatial aggregations of prey (e.g. attraction of piscivoious birds to schools of pelagic fish), or outbreaks of disease or parasitism at high population densities (e.g. high incidence of Ichthyophonus hoferi in herring during period of high stock density, Mellergaard and Spanggaard, 1997). In the model, the biomass killed by density dependent mortality was retained within the food web by allowing for scavenge feeding on corpses by carnivorous/scavenging benthos, adult demersal fish and birds/mammals.

\subsection{Temperature dependency}


For the uptake and metabolic parameters identified as being subject to temperature dependency, the response was represented by a $\mathrm{Q}_{10}$ function:

$k=\exp \left(\frac{1}{10}\left(T-T_{R}\right) \cdot \log _{e} Q_{10}+\log _{e} k_{T R}\right)$

where $T_{R}$ was the reference temperature and $k_{T R}$ was the value of the parameter $k$ at the reference temperature. Parameters assumed to be sensitive to temperature were all uptake rates, background metabolism, and bacterial mineralization, nitrification and denitrification.

\subsection{Fishing}

Two key effects of fishing on the food web were represented in the model, in addition to the obvious mortality inflicted on fish and the removal of biomass from the system. Targeted catches of fish and benthos by four fishing 'fleets' were expressed as proportions of biomass captured per day (harvest rates). The four fleets were pelagic and demersal fisheries which targeted adult pelagic and demersal fish respectively, and two types of shellfish fisheries which targeted the suspension/deposit and carnivorous/scavenge feeding benthos. The two additional effects of fishing were bycatching and discarding. By-catch refers to the collateral mortality inflicted on nontarget guilds by a fishery, and was represented in the model as by-catch of benthos guilds by the demersal fishery. Discarding includes a) accidental or intentional (due to quota restrictions) spillage of marketable targeted catch from nets during gear recovery, b) throwing overboard of dead biomass of un-marketable species, and under-size or low value individuals of otherwise marketable species, and c) offal removed from the fish during gutting operations which is thrown overboard. In addition, though not normally regarded as a discard, fish which escape through net meshes but are damaged and do not survive, are functionally equivalent to discards. These components of the catch formed a potential food resource in the model for demersal fish, birds and mammals, and were also converted to corpses at a fixed daily rate representing settlement to the seabed.

There are few data on the collateral mortality rates inflicted on benthos fauna due to demersal fishing. As a rough estimate a collateral harvesting rate of 0.001times the demersal fish harvesting rate was applied to both the suspension/deposit and carnivorous benthos guilds to represent by-catch. $100 \%$ of this by-catch was considered to be rejected at sea, so was retained in the model as discards. The bycatch in the model also functionally included fauna which are damaged and killed by the fishing gear but not actually retained by the net, which could be the case for many fragile benthic taxa.

Discarding of targeted guilds was represented as either a fixed or a variable proportion of catch. Fisheries for pelagic fish and benthos are generally highly targeted, that is, the catching process discriminates by virtue of location, fishing gear or technology (e.g. sonar) between species and, in the case of pelagic fish, sizes which are of marketable value. In addition, catches of pelagic fish are usually landed in bulk and not sorted or graded at sea. Hence, as a starting assumption the proportion of catch discarded from these fisheries was expected to be relatively low and constant. In contrast, fisheries for demersal fish are generally indiscriminate and the catch is intensively sorted and graded at sea. There is clear evidence that the proportion by weight of large fish in the North Sea demersal community has declined over time since the 1970's in parallel with stock abundances (Greenstreet et al. 2010). Hence, we would expect the proportion by weight of discardable fish (smaller than the 
minimum landing size) to have increased in inverse relation to biomass. The discarded fraction of demersal fish catches $\left(\operatorname{disc}_{\mathrm{d}}\right)$ was therefore parameterized as a function of adult demersal biomass:

$\operatorname{disc}_{\mathrm{d}}=\exp (-\mathrm{dfd} . \mathrm{Fd})$

where dfd was a constant $(\mathrm{dfd}<1)$ and $\mathrm{Fd}$ was the biomass of adult demersal fish.

Catch which was not discarded was referred to as 'landings' and was removed as an export flux from the model.

\section{Physical exchanges}

\subsection{Vertical exchange across the interface between water column layers}

Vertical exchanges between layers in the water column were represented as a simple diffusive process in the model. Diffusive processes produce net fluxes of material only when there is a concentration gradient across the interface between neighboring compartments, with the flux determined by a diffusion coefficient $\left(\mathrm{m}^{2} \mathrm{~d}^{-1}\right)$. However, since the model only simulated the difference in concentration between the two layers, and not the gradient across the interface, the length term over which the gradient acted was specified as a separate time series parameter.

\subsection{Vertical exchange across the sediment water interface}

As for vertical exchanges in the water column, the material flux of dissolved constituents across the sediment-water interface in the model was given by product of the concentration difference between sediment pore waters and the overlying water column layer, a diffusion coefficient, and an assumed length scale of action. Pore water concentrations were given by assuming that the mass of state variable in the sediment was uniformly distributed over the sediment layer which was of fixed thickness and uniform porosity (proportion by volume of water in the sediment).

\subsection{Horizontal advection}

Horizontal advection was represented by a volume inflow to the surface and deep layer (parameterised as a proportion of layer volume inflowing per day). To conserve volume, a balancing outflow was assumed from each layer. All horizontal inflow to the surface layer was assumed to exit via the surface layer. However, a proportion (between 0 and 1) of the inflow to the deep layer was potentially allowed to upwell vertically into the surface layer, augmenting the surface layer outflow. All components which were subject to vertical diffusion (nitrate, ammonia, suspended detritus, and phytoplankton) were also eligible to be advected vertically and horizontally. Ocean boundary concentrations $\left(\mathrm{mM} \mathrm{N}^{-3} \mathrm{~m}^{-3}\right)$ in inflows to the system were set as external values.

\subsection{River inputs}

Nutrient and detritus inputs from rivers were confined to the surface layer and represented by a volume inflow (proportion of surface layer volume per day) with given concentrations of nutrient load $\left(\mathrm{mM} \mathrm{N} . \mathrm{m}^{-3}\right)$. The volume input from rivers 
generated a corresponding outflow volume from the surface layer, which was added to that generated by horizontal advection.

\subsection{Atmospheric input of nutrient}

Deposition of nitrate and ammonia to the surface layer from the atmosphere was represented by an external driving dataset of fluxes $\left(\mathrm{mM} \mathrm{N} \cdot \mathrm{m}^{-2} \cdot \mathrm{d}^{-1}\right)$

\section{References}

Dortch, Q., 1990. The interaction between ammonium and nitrate uptake in phytoplankton. Marine Ecology Progress Series 61, 183-201.

Forget, M.-H., Sathyendranath, S., Platt, T., Pommier, J., Vis, C., Kyewalyanga, M.S., Hudon, C., 2007. Extraction of photosynthesis-irradiance parameters from phytoplankton production data: demonstration in various aquatic systems. Journal of Plankton Research 29, 249-262.

Greenstreet, S. P. R., Rogers, S. I., Rice, J. C., Piet, G. J., Guirey, E. J., Fraser, H. M., Fryer, R. J., 2010. Development of the EcoQO for the North Sea fish community. ICES Journal of Marine Science (DOI 10.1093/icesjms/fsq156).

Lipshultz, F., Owens, N.J.P., 1996. An assessment of nitrogen fixation as a source of nitrogen to the North Atlantic Ocean. Biogeochemistry 35, 261-274.

Lund-Hansen, L.C., Sorensen, H.M., 2009. Parameterisation of surface irradiance and primary production in Arhus Bay, SW Kattegat, Baltic Sea. Hydrobiologia 620, 173-179.

Mellergaard, S., Spanggaard, B., 1997. An Ichthyophonus hoferi epizootic in herring in the North Sea, the Skagerrak, the Kattegat and the Baltic Sea. Diseases of Aquatic Organisms 28, 191-199.

Platt, T., Sathyendranath, S. Ravindran, P., 1990. Primary production by phytoplankton: analytic solutions for daily rates per unit area of water surface. Procedings of the Royal Society of London Series B 241, 101-111.

Tett, P., 1981. Modelling phytoplankton production at shelf sea fronts. Philosophical Transactions of the Royal Society of London A 302, 605-615. 
Table S1

State variables and notations. Units of all variables are $\mathrm{mMN} \cdot \mathrm{m}^{-2}$ in a given depth layer.

\begin{tabular}{ll}
\hline Term & Symbol \\
\hline Surface detritus & $\mathrm{D}_{\mathrm{s}}$ \\
\hline Deep detritus & $\mathrm{D}_{\mathrm{d}}$ \\
\hline Sediment detritus & $\mathrm{D}_{\mathrm{x}}$ \\
\hline Fishery discards & $\mathrm{D}_{\mathrm{f}}$ \\
\hline Corpses & $\mathrm{D}_{\mathrm{c}}$ \\
\hline Surface ammonia & $\mathrm{A}_{\mathrm{s}}$ \\
\hline Deep ammonia & $\mathrm{A}_{\mathrm{d}}$ \\
\hline Sediment ammonia & $\mathrm{A}_{\mathrm{x}}$ \\
\hline Surface nitrate & $\mathrm{N}_{\mathrm{s}}$ \\
\hline Deep nitrate & $\mathrm{N}_{\mathrm{d}}$ \\
\hline Sediment nitrate & $\mathrm{N}_{\mathrm{x}}$ \\
\hline Surface phytoplankton & $\mathrm{P}_{\mathrm{s}}$ \\
\hline Deep phytoplankton & $\mathrm{P}_{\mathrm{d}}$ \\
\hline Mesozooplankton & $\mathrm{H}$ \\
\hline Carnivorous zooplankton & $\mathrm{C}$ \\
\hline Suspension/deposit feeding benthos & $\mathrm{Bs}$ \\
\hline Carnivorous/scavenge feeding benthos & $\mathrm{Bc}$ \\
\hline Pelagic fish larvae & $\mathrm{FLp}$ \\
\hline Demersal fish larvae & $\mathrm{FLd}$ \\
\hline Pelagic fish adults & $\mathrm{Fp}$ \\
\hline Demersal fish adults & $\mathrm{Fd}$ \\
\hline Birds/mammals & $\mathrm{J}$ \\
\hline
\end{tabular}


Table S2

Static physical setup parameters.

\begin{tabular}{|c|c|c|}
\hline Parameter & Symbol & Description \\
\hline $\begin{array}{l}\text { Thicknesses of the surface } \\
\text { water column layer }\end{array}$ & $\mathrm{T}_{\mathrm{s}}$ & $\begin{array}{l}\text { Vertical distance between the sea surface and } \\
\text { the base of mixed layer }\end{array}$ \\
\hline $\begin{array}{l}\text { Thicknesses of the deep } \\
\text { water column layer }\end{array}$ & $\mathrm{T}_{\mathrm{d}}$ & $\begin{array}{l}\text { Vertical distance between the base of mixed } \\
\text { layer and the seabed }\end{array}$ \\
\hline $\begin{array}{l}\text { Thickness of benthic } \\
\text { feeding layer }\end{array}$ & $\mathrm{T}_{\mathrm{bl}}$ & $\begin{array}{l}\text { Bottom boundary layer (contained within the } \\
\text { deep layer) in which benthos have access to } \\
\text { phytoplankton and suspended detritus (must } \\
\text { be less than } T_{d} \text { ). }\end{array}$ \\
\hline $\begin{array}{l}\text { Thickness of the sediment } \\
\text { layer }\end{array}$ & $\mathrm{T}_{\mathrm{x}}$ & $\begin{array}{l}\text { Vertical depth over which sediment } \\
\text { constituents are assumed to be well mixed }\end{array}$ \\
\hline $\begin{array}{l}\text { Thickness of the sediment- } \\
\text { water diffusion layer }\end{array}$ & $\mathrm{T}_{\mathrm{Vx}}$ & $\begin{array}{l}\text { Boundary layer thickness at the sediment- } \\
\text { water interface, over which the diffusion } \\
\text { coefficient between deep water and sediment } \\
\text { pore water is assumed to act }\end{array}$ \\
\hline Sediment-water diffusivity & $\mathrm{V}_{\mathrm{x}}$ & $\begin{array}{l}\text { A constant coefficient governing the vertical } \\
\text { flux between the sediment pore water and } \\
\text { the deep water layer. }\end{array}$ \\
\hline Sediment porosity & $\operatorname{por}_{\mathrm{x}}$ & $\begin{array}{l}\text { Proportion by volume of water in seabed } \\
\text { sediment. }\end{array}$ \\
\hline
\end{tabular}


Table S3

Time dependent external driving variables.

\begin{tabular}{|c|c|c|}
\hline Term & Symbol & Description \\
\hline Sea surface irradiance & $\mathrm{L}(\mathrm{t})$ & $\begin{array}{l}\text { A daily resolution time series cosine function } \\
\text { varying between a winter minimum }\left(\mathrm{L}_{\mathrm{w}}\right) \text { on } \\
\text { day } 0 \text { and } 360 \text {, and a summer maximum }\left(\mathrm{L}_{\mathrm{s}}\right) \\
\text { on day } 180\end{array}$ \\
\hline $\begin{array}{l}\text { Vertical attenuation } \\
\text { coefficient of irradiance } \\
\text { (base e) }\end{array}$ & $\operatorname{Kvert}(\mathrm{t})$ & $\begin{array}{l}\text { A daily resolution time series of the log-e } \\
\text { coefficient of vertical attenuation. The } \\
\text { proportion of surface irradiance representing } \\
\text { the mean light intensity in the surface layer } \\
\text { is then derived from the integral of the light } \\
\text { profile }\left(\mathrm{L}_{\mathrm{depth}}=\mathrm{L} . \mathrm{e}^{-\mathrm{kvert} . d e p t h}\right) \text { ie. } \\
\left(\left((1 / \mathrm{kvert})^{*} \mathrm{e}^{-\mathrm{kvert} .0}\right)-\left((1 / \mathrm{kvert}) \mathrm{e}^{- \text {-kvert.thick_s }}\right)\right. \\
) / \text { thick_s }\end{array}$ \\
\hline $\begin{array}{l}\text { Temperature in each } \\
\text { vertical layer of the model }\end{array}$ & $\mathrm{TZ}(\mathrm{t})$ & $\begin{array}{l}\text { A daily resolution time series of sea } \\
\text { temperatures for each model layer. }\end{array}$ \\
\hline $\begin{array}{l}\text { Vertical diffusion } \\
\text { coefficient }\end{array}$ & $\mathrm{V}(\mathrm{t})$ & $\begin{array}{l}\text { A daily resolution time series of either a } \\
\text { constant value or a cosine function } \\
\text { representing the seasonal variation of } \\
\text { vertical diffusion coefficient. }\end{array}$ \\
\hline $\begin{array}{l}\text { Vertical diffusion length } \\
\text { scale }\end{array}$ & $\mathrm{T}_{\mathrm{Vsd}}(\mathrm{t})$ & $\begin{array}{l}\text { The length scale over which vertical } \\
\text { diffusion acts at the interface between water } \\
\text { column layers - a derived function of the } \\
\text { magnitude of the diffusion rate. }\end{array}$ \\
\hline $\begin{array}{l}\text { Freshwater input to the } \\
\text { surface layer from rivers }\end{array}$ & $R(t)$ & $\begin{array}{l}\text { A daily resolution time series of the volume } \\
\text { of freshwater introduced to the system from } \\
\text { rivers as a proportion of surface layer } \\
\text { volume per day }\end{array}$ \\
\hline $\begin{array}{l}\text { Horizontal advection } \\
\text { inflow from the ocean to } \\
\text { the surface layer }\end{array}$ & $\mathrm{I}_{\mathrm{s}}(\mathrm{t})$ & $\begin{array}{l}\text { A daily resolution time series or constant } \\
\text { value of the inflow volume to the surface } \\
\text { layer as a proportion of surface layer volume } \\
\text { per day }\end{array}$ \\
\hline $\begin{array}{l}\text { Horizontal advection } \\
\text { inflow from the ocean to } \\
\text { the deep layer }\end{array}$ & $\mathrm{I}_{\mathrm{d}}(\mathrm{t})$ & $\begin{array}{l}\text { A daily resolution time series or constant } \\
\text { value of the inflow volume to the deep layer } \\
\text { as a proportion of deep layer volume per day }\end{array}$ \\
\hline $\begin{array}{l}\text { Proportion of deep inflow } \\
\text { volume upwellng into the } \\
\text { surface later }\end{array}$ & $\mathrm{p}_{\text {Id }}$ & $\begin{array}{l}\text { A daily resolution time series or constant } \\
\text { value. The proportion of deep inflow which } \\
\text { is not upwelled, is treated as an outflow from } \\
\text { the deep layer }\end{array}$ \\
\hline $\begin{array}{l}\text { Horizontal outflow volume } \\
\text { from the surface layer to } \\
\text { the ocean }\end{array}$ & $\mathrm{O}_{\mathrm{s}}(\mathrm{t})$ & $\begin{array}{l}\text { Proportion of surface layer advected } \\
\text { horizontally out of the system each day }= \\
I_{s}(t)+p_{I d} *\left(T_{d} * I_{d}(t)\right) / T_{s}+R(t)\end{array}$ \\
\hline $\begin{array}{l}\text { External input of nitrogen } \\
\text { to the surface layer from } \\
\text { the atmosphere }\end{array}$ & {[]$_{A}(t)$} & $\begin{array}{l}\text { Mass of nitrate and ammonia introduced to } \\
\text { the system from the atmosphere (molesN m } \\
\mathrm{d}^{-1} \text { ) as a constant or time series }\end{array}$ \\
\hline $\begin{array}{l}\text { Concentrations of nitrogen } \\
\text { in river waters flowing } \\
\text { into the surface layer }\end{array}$ & {[]$_{R}(t)$} & $\begin{array}{l}\text { Nitrate and ammonia concentrations } \\
\left(\mathrm{molesN} \mathrm{m}^{-3}\right) \text { in river waters as a constant or } \\
\text { time series }\end{array}$ \\
\hline
\end{tabular}




\begin{tabular}{|c|c|c|}
\hline $\begin{array}{l}\text { Ocean boundary } \\
\text { concentrations of } \\
\text { horizontally advected } \\
\text { components in the surface } \\
\text { and deep layers }\end{array}$ & $\begin{array}{l}{[]_{\mathrm{bs}}(\mathrm{t})} \\
\text { and } \\
{[]_{\mathrm{bd}}(\mathrm{t})}\end{array}$ & $\begin{array}{l}\text { Nitrate, ammonia, detritus, and } \\
\text { phytoplankton were susceptible to horizontal } \\
\text { advection and ocean boundary } \\
\text { concentrations (moles } \mathrm{N}^{-3} \text { ) of each are } \\
\text { required as a constant or time series }\end{array}$ \\
\hline $\begin{array}{l}\text { Pelagic fish spawning } \\
\text { pattern }\end{array}$ & $\operatorname{Pspn}(t)$ & $\begin{array}{l}\text { A daily resolution time series of the } \\
\text { proportion of adult pelagic fish biomass shed } \\
\text { as eggs per day }\end{array}$ \\
\hline $\begin{array}{l}\text { Demersal fish spawning } \\
\text { pattern }\end{array}$ & $\operatorname{Dspn}(t)$ & $\begin{array}{l}\text { A daily resolution time series of the } \\
\text { proportion of adult demersal fish biomass } \\
\text { shed as eggs per day }\end{array}$ \\
\hline $\begin{array}{l}\text { Pelagic fish recruitment } \\
\text { pattern }\end{array}$ & $\operatorname{Prec}(t)$ & $\begin{array}{l}\text { A daily resolution time series of the } \\
\text { proportion of larval pelagic fish biomass } \\
\text { recruiting to the adult pelagic stock per day }\end{array}$ \\
\hline $\begin{array}{l}\text { Demersal fish recruitment } \\
\text { pattern }\end{array}$ & $\operatorname{Drec}(\mathrm{t})$ & $\begin{array}{l}\text { A daily resolution time series of the } \\
\text { proportion of larval demersal fish biomass } \\
\text { recruiting to the adult demersal stock per day }\end{array}$ \\
\hline $\begin{array}{l}\text { Fishery extraction rate } \\
\text { from benthos } \\
\text { suspension/deposit feeders }\end{array}$ & $\mathrm{X}_{\mathrm{Bs}}$ & $\begin{array}{l}\text { A daily resolution time sereies of the } \\
\text { proportion of benthos suspension feeder } \\
\text { biomass extracted per day }\end{array}$ \\
\hline $\begin{array}{l}\text { Fishery extraction rate } \\
\text { from benthos carnivores }\end{array}$ & $\mathrm{X}_{\mathrm{Bc}}$ & $\begin{array}{l}\text { A daily resolution time sereies of the } \\
\text { proportion of benthos carnivore biomass } \\
\text { extracted per day }\end{array}$ \\
\hline $\begin{array}{l}\text { Fishery extraction rate } \\
\text { from pelagic fish }\end{array}$ & $X_{F p}$ & $\begin{array}{l}\text { A daily resolution time sereies of the } \\
\text { proportion of pelagic fish biomass extracted } \\
\text { per day }\end{array}$ \\
\hline $\begin{array}{l}\text { Fishery extraction rate } \\
\text { from demersal fish }\end{array}$ & $\mathrm{X}_{\mathrm{Fd}}$ & $\begin{array}{l}\text { A daily resolution time sereies of the } \\
\text { proportion of demersal fish biomass } \\
\text { extracted per day }\end{array}$ \\
\hline
\end{tabular}




\section{Table S4}

Static parameters of the model.

\begin{tabular}{|c|c|}
\hline Parameter & Symbol \\
\hline Preference of consumer guild $(\mathrm{x})$ for resource guild $(\mathrm{y})$ & $\operatorname{pref}_{\mathrm{y}-\mathrm{x}}$ \\
\hline $\begin{array}{l}\text { Temperature corrected weight specific maximum uptake rate }\left(\mathrm{d}^{-1}\right) \text { of } \\
\text { resource guild }(\mathrm{y}) \text { by consumer guild }(\mathrm{x})\end{array}$ & $\mathrm{U}_{\max (\mathrm{x})}$ \\
\hline Half-saturation concentration of resource for consumer guild $(\mathrm{x})$ & $\mathrm{h}_{\mathrm{x}}$ \\
\hline $\begin{array}{l}\text { Assimilation efficiency of heterotroph guild (x) (proportion of ingestate } \\
\text { converted into body mass) }\end{array}$ & $a_{x}$ \\
\hline $\begin{array}{l}\text { Temperature corrected background metabolic rate of heterotroph guild } \\
\text { (x) (proportion of nitrogen biomass which was converted to ammonia } \\
\text { per day). }\end{array}$ & $\mathrm{e}_{\mathrm{x}}$ \\
\hline $\begin{array}{l}\text { Temperature corrected remineralisation of suspended detritus in the } \\
\text { surface water column layer to ammonia, expressed as the proportion of } \\
\text { suspended detritus nitrogen converted to ammonia per day }\end{array}$ & $\mathrm{m}_{\mathrm{s}}$ \\
\hline $\begin{array}{l}\text { Temperature corrected remineralisation of suspended detritus in the } \\
\text { deep water column layer to ammonia, expressed as the proportion of } \\
\text { suspended detritus nitrogen converted to ammonia per day }\end{array}$ & $\mathrm{m}_{\mathrm{d}}$ \\
\hline $\begin{array}{l}\text { Temperature corrected remineralisation of sediment detritus to } \\
\text { ammonia, expressed as the proportion of sediment detritus nitrogen } \\
\text { converted to ammonia per day }\end{array}$ & $\mathrm{m}_{\mathrm{x}}$ \\
\hline $\begin{array}{l}\text { Temperature corrected nitrification rate of ammonia to nitrate in the } \\
\text { surface layer of the water column, expressed as the proportion of } \\
\text { ammonia converted to nitrate per day }\end{array}$ & $\mathrm{n}_{\mathrm{s}}$ \\
\hline $\begin{array}{l}\text { Temperature corrected nitrification rate of ammonia to nitrate in the } \\
\text { deep layer of the water column, expressed as the proportion of ammonia } \\
\text { converted to nitrate per day }\end{array}$ & $\mathrm{n}_{\mathrm{d}}$ \\
\hline $\begin{array}{l}\text { Temperature corrected nitrification rate of ammonia to nitrate in the } \\
\text { sediment pore waters, expressed as the proportion of ammonia } \\
\text { converted to nitrate per day }\end{array}$ & $\mathrm{n}_{\mathrm{x}}$ \\
\hline $\begin{array}{l}\text { Temperature corrected denitrification rate of nitrate in the surface layer, } \\
\text { expressed as the proportion of nitrate lost from the system to nitrogen } \\
\text { gas per day }\end{array}$ & $\mathrm{d}_{\mathrm{s}}$ \\
\hline $\begin{array}{l}\text { Temperature corrected denitrification rate of nitrate in the deep layer, } \\
\text { expressed as the proportion of nitrate lost from the system to nitrogen } \\
\text { gas per day }\end{array}$ & $d_{d}$ \\
\hline $\begin{array}{l}\text { Temperature corrected denitrification rate of nitrate in the sediment pore } \\
\text { water layer, expressed as the proportion of nitrate lost from the system } \\
\text { to nitrogen gas per day }\end{array}$ & $d_{x}$ \\
\hline $\begin{array}{l}\text { Death rate of phytoplankton in the surface layer, expressed as the } \\
\text { proportion of surface phytoplankton exported to detritus per day }\end{array}$ & $\mathrm{X}_{\mathrm{S}}$ \\
\hline $\begin{array}{l}\text { Death rate of phytoplankton in the deep layer, expressed as the } \\
\text { proportion of deep phytoplankton exported to detritus per day }\end{array}$ & $\mathrm{x}_{\mathrm{d}}$ \\
\hline $\begin{array}{l}\text { Density-dependent mortality rate of carnivorous zooplankton, expressed } \\
\text { as the proportion of biomass exported to seabed corpses, per unit } \\
\text { biomass, per day }\end{array}$ & $\mathrm{z}_{\mathrm{C}}$ \\
\hline $\begin{array}{l}\text { Density-dependent mortality rate of carnivorous benthos, expressed as } \\
\text { the proportion of biomass exported to seabed corpses, per unit biomass, }\end{array}$ & $\mathrm{Z}_{\mathrm{Bc}}$ \\
\hline
\end{tabular}




\begin{tabular}{ll}
\hline per day & \\
\hline $\begin{array}{l}\text { Density-dependent mortality rate of adult pelagic fish, expressed as the } \\
\text { proportion of biomass exported to seabed corpses, per unit biomass, per } \\
\text { day }\end{array}$ & \\
\hline $\begin{array}{l}\text { Density-dependent mortality rate of adult demersal fish, expressed as } \\
\text { the proportion of biomass exported to seabed corpses, per unit biomass, } \\
\text { per day }\end{array}$ & $\mathrm{Z}_{\mathrm{Fd}}$ \\
\hline $\begin{array}{l}\text { Density-dependent mortality rate of birds/mammals, expressed as the } \\
\text { proportion of biomass exported to seabed corpses, per unit biomass, per } \\
\text { day }\end{array}$ & $\mathrm{Z}_{\mathrm{J}}$ \\
\hline $\begin{array}{l}\text { Sinking rate of detritus in the surface layer, expressed as the proportion } \\
\text { of surface layer detritus exported per day to the deep layer }\end{array}$ & $\mathrm{X}_{\text {sink_s }}$ \\
\hline $\begin{array}{l}\text { Sinking rate of detritus in the deep layer, expressed as the proportion of } \\
\text { deep layer detritus exported per day to the sediment }\end{array}$ & $\mathrm{X}_{\text {sink_d }}$ \\
\hline Rate of conversion of fishery discards to seabed corpses & $\mathrm{X}_{\text {disc corp }_{s}}$ \\
\hline Rate of conversion of seabed corpses to sediment detritus & $\mathrm{X}_{\text {corp }_{\text {sed }}}$ \\
\hline Fraction of pelagic fish catch which is discarded at sea & disc \\
\hline $\begin{array}{l}\text { Coefficient for biomass dependency of the fraction of demersal fish } \\
\text { catch which is discarded at sea }\end{array}$ & dfd $^{\text {Fraction of carnivorous benthos catch which is discarded at sea }}$ \\
\hline Fraction of suspension feeding benthos catch which is not landed & disc $_{\mathrm{Bc}}$ \\
\hline
\end{tabular}




\section{Table S5}

Uptake equations of the model.

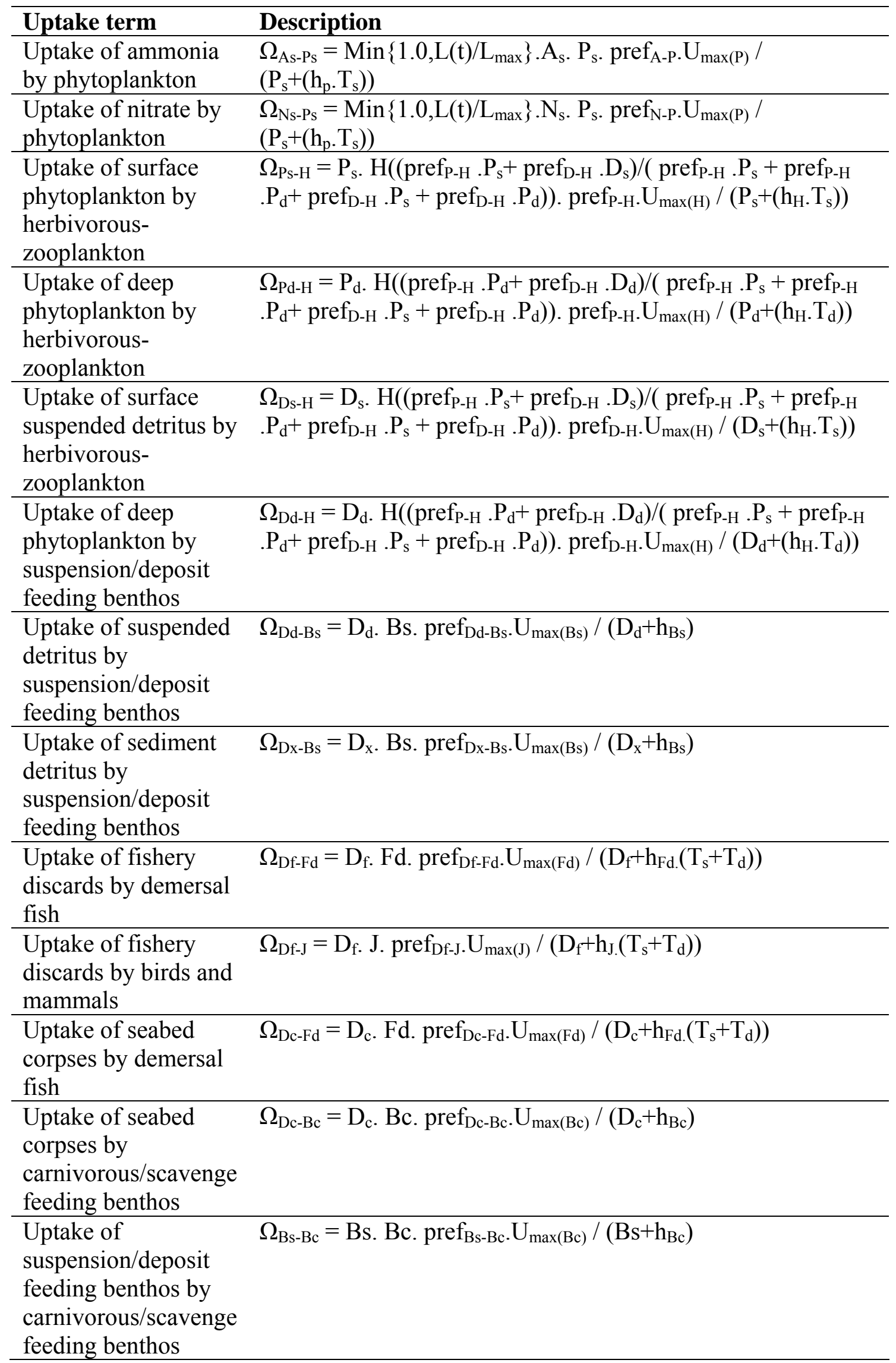




\begin{tabular}{|c|c|}
\hline $\begin{array}{l}\text { Uptake of } \\
\text { herbivorous- } \\
\text { zooplankton by } \\
\text { carnivorous } \\
\text { zooplankton }\end{array}$ & $\Omega_{\mathrm{H}-\mathrm{C}}=$ H. C. $\operatorname{pref}_{\mathrm{H}-\mathrm{C}} \cdot \mathrm{U}_{\max (\mathrm{C})} /\left(\mathrm{H}+\mathrm{h}_{\mathrm{C}}\left(\mathrm{T}_{\mathrm{s}}+\mathrm{T}_{\mathrm{d}}\right)\right)$ \\
\hline $\begin{array}{l}\text { Uptake of pelagic } \\
\text { fish larvae by } \\
\text { carnivorous } \\
\text { zooplankton }\end{array}$ & $\Omega_{\mathrm{FLp}-\mathrm{C}}=$ FLp. C. pref $f_{\mathrm{FLp}-\mathrm{C}} \cdot \mathrm{U}_{\max (\mathrm{C})} /\left(\mathrm{FLp}+\mathrm{h}_{\mathrm{C} .}\left(\mathrm{T}_{\mathrm{s}}+\mathrm{T}_{\mathrm{d}}\right)\right)$ \\
\hline $\begin{array}{l}\text { Uptake of demersal } \\
\text { fish larvae by } \\
\text { carnivorous } \\
\text { zooplankton }\end{array}$ & $\Omega_{\mathrm{FLd}-\mathrm{C}}=$ FLd. C. $\operatorname{pref}_{\mathrm{FLd}-\mathrm{C}} \cdot \mathrm{U}_{\max (\mathrm{C})} /\left(\mathrm{FLd}+\mathrm{h}_{\mathrm{C}} \cdot\left(\mathrm{T}_{\mathrm{s}}+\mathrm{T}_{\mathrm{d}}\right)\right)$ \\
\hline $\begin{array}{l}\text { Uptake of } \\
\text { herbivorous- } \\
\text { zooplankton by } \\
\text { pelagic fish larvae }\end{array}$ & $\Omega_{\mathrm{H}-\mathrm{FLp}}=$ H. FLp. pref $\mathrm{H}_{\mathrm{H}-\mathrm{F} p} \cdot \mathrm{U}_{\max (\mathrm{FLp})} /\left(\mathrm{H}+\mathrm{h}_{\mathrm{FLp} .}\left(\mathrm{T}_{\mathrm{s}}+\mathrm{T}_{\mathrm{d}}\right)\right)$ \\
\hline $\begin{array}{l}\text { Uptake of } \\
\text { herbivorous- } \\
\text { zooplankton by } \\
\text { pelagic fish }\end{array}$ & $\Omega_{\mathrm{H}-\mathrm{Fp}}=\mathrm{H}$. Fp. pref $\mathrm{H}_{\mathrm{H}-\mathrm{F}} \cdot \mathrm{U}_{\max (\mathrm{Fp})} /\left(\mathrm{H}+\mathrm{h}_{\mathrm{Fp} .}\left(\mathrm{T}_{\mathrm{s}}+\mathrm{T}_{\mathrm{d}}\right)\right)$ \\
\hline $\begin{array}{l}\text { Uptake of } \\
\text { carnivorous } \\
\text { zooplankton by } \\
\text { pelagic fish }\end{array}$ & $\Omega_{\mathrm{C}-\mathrm{Fp}}=$ C. Fp. pref $\mathrm{C}-\mathrm{Fp}_{\mathrm{p}} \cdot \mathrm{U}_{\max (\mathrm{Fp})} /\left(\mathrm{C}+\mathrm{h}_{\mathrm{Fp} .}\left(\mathrm{T}_{\mathrm{s}}+\mathrm{T}_{\mathrm{d}}\right)\right)$ \\
\hline $\begin{array}{l}\text { Uptake of pelagic } \\
\text { fish larvae by pelagic } \\
\text { fish }\end{array}$ & $\Omega_{\mathrm{FLp}-\mathrm{Fp}}=$ FLp. Fp. pref $f_{\mathrm{FL}-\mathrm{Fp}} \cdot \mathrm{U}_{\max (\mathrm{Fp})} /\left(\mathrm{FLp}+\mathrm{h}_{\mathrm{Fp} .}\left(\mathrm{T}_{\mathrm{s}}+\mathrm{T}_{\mathrm{d}}\right)\right)$ \\
\hline $\begin{array}{l}\text { Uptake of demersal } \\
\text { fish larvae by pelagic } \\
\text { fish }\end{array}$ & $\Omega_{\mathrm{FLd}-\mathrm{Fp}}=\mathrm{FLd}$. Fp. pref $f_{\mathrm{FLd}-\mathrm{Fp}} \cdot \mathrm{U}_{\max (\mathrm{Fp})} /\left(\mathrm{FLd}+\mathrm{h}_{\mathrm{Fp} .}\left(\mathrm{T}_{\mathrm{s}}+\mathrm{T}_{\mathrm{d}}\right)\right)$ \\
\hline $\begin{array}{l}\text { Uptake of } \\
\text { herbivorous- } \\
\text { zooplankton by } \\
\text { demersal fish larvae }\end{array}$ & $\Omega_{\mathrm{H}-\mathrm{FLd}}=\mathrm{H} . \mathrm{FLd} . \mathrm{pref}_{\mathrm{H}-\mathrm{FLd}} \cdot \mathrm{U}_{\max (\mathrm{FLd})} /\left(\mathrm{H}+\mathrm{h}_{\mathrm{FLd}}\left(\mathrm{T}_{\mathrm{s}}+\mathrm{T}_{\mathrm{d}}\right)\right)$ \\
\hline $\begin{array}{l}\text { Uptake of } \\
\text { carnivorous } \\
\text { zooplankton by } \\
\text { demersal fish }\end{array}$ & $\Omega_{\mathrm{C}-\mathrm{Fd}}=$ C. Fd. pref $\mathrm{C}-\mathrm{Fd}_{2} \mathrm{U}_{\max (\mathrm{Fd})} /\left(\mathrm{C}+\mathrm{h}_{\mathrm{Fd}} .\left(\mathrm{T}_{\mathrm{s}}+\mathrm{T}_{\mathrm{d}}\right)\right)$ \\
\hline $\begin{array}{l}\text { Uptake of } \\
\text { suspension/deposit } \\
\text { feeding benthos by } \\
\text { demersal fish }\end{array}$ & $\Omega_{\text {Bs-Fd }}=$ Bs. Fd. pref $f_{\text {Bs-Fd. }} \cdot U_{\max (F d)} /\left(B s+h_{F d}\left(T_{s}+T_{d}\right)\right)$ \\
\hline $\begin{array}{l}\text { Uptake of } \\
\text { carnivorous/scavenge } \\
\text { feeding benthos by } \\
\text { demersal fish }\end{array}$ & $\Omega_{\mathrm{Bc}-\mathrm{Fd}}=$ Bc. Fd. pref $\mathrm{Bc}_{\mathrm{Bd} \cdot} \cdot \mathrm{U}_{\max (\mathrm{Fd})} /\left(\mathrm{Bc}+\mathrm{h}_{\mathrm{Fd} .}\left(\mathrm{T}_{\mathrm{s}}+\mathrm{T}_{\mathrm{d}}\right)\right)$ \\
\hline $\begin{array}{l}\text { Uptake of pelagic } \\
\text { fish larvae by } \\
\text { demersal fish }\end{array}$ & $\Omega_{\mathrm{FLp}-\mathrm{Fd}}=$ FLp. Fd. pref $f_{\mathrm{FL}-\mathrm{Fd} .} \mathrm{U}_{\max (\mathrm{Fd})} /\left(\mathrm{FLp}+\mathrm{h}_{\mathrm{Fd} .}\left(\mathrm{T}_{\mathrm{s}}+\mathrm{T}_{\mathrm{d}}\right)\right)$ \\
\hline
\end{tabular}




\begin{tabular}{|c|c|}
\hline $\begin{array}{l}\text { Uptake of demersal } \\
\text { fish larvae by } \\
\text { demersal fish }\end{array}$ & $\Omega_{\mathrm{FLd}-\mathrm{Fd}}=$ FLd. Fd. pref $\mathrm{FLd}_{\mathrm{Fd}} \cdot \mathrm{U}_{\max (\mathrm{Fd})} /\left(\mathrm{FLd}+\mathrm{h}_{\mathrm{Fd} .}\left(\mathrm{T}_{\mathrm{s}}+\mathrm{T}_{\mathrm{d}}\right)\right)$ \\
\hline $\begin{array}{l}\text { Uptake of pelagic } \\
\text { fish by demersal fish }\end{array}$ & $\Omega_{\mathrm{Fp}-\mathrm{Fd}}=\mathrm{Fp} . \mathrm{Fd}$. pref $_{\mathrm{Fp}-\mathrm{Fd}} \cdot \mathrm{U}_{\max (\mathrm{Fd})} /\left(\mathrm{Fp}+\mathrm{h}_{\mathrm{Fd}} .\left(\mathrm{T}_{\mathrm{s}}+\mathrm{T}_{\mathrm{d}}\right)\right)$ \\
\hline $\begin{array}{l}\text { Uptake of pelagic } \\
\text { fish by } \\
\text { birds/mammals }\end{array}$ & $\Omega_{\mathrm{Fp}-\mathrm{J}}=$ Fp. J. $\operatorname{pref}_{\mathrm{Fp}-\mathrm{J} .} \mathrm{U}_{\max (\mathrm{J})} /\left(\mathrm{Fp}+\mathrm{h}_{\mathrm{J}}\left(\mathrm{T}_{\mathrm{s}}+\mathrm{T}_{\mathrm{d}}\right)\right)$ \\
\hline $\begin{array}{l}\text { Uptake of demersal } \\
\text { fish by demersal fish }\end{array}$ & $\Omega_{\mathrm{Fd}-\mathrm{Fd}}=\mathrm{Fd} . \mathrm{Fd} . \operatorname{pref}_{\mathrm{Fd}-\mathrm{Fd}} \cdot \mathrm{U}_{\max (\mathrm{Fd})} /\left(\mathrm{Fd}+\mathrm{h}_{\mathrm{Fd}} .\left(\mathrm{T}_{\mathrm{s}}+\mathrm{T}_{\mathrm{d}}\right)\right)$ \\
\hline $\begin{array}{l}\text { Uptake of demersal } \\
\text { fish by } \\
\text { birds/mammals }\end{array}$ & $\Omega_{\mathrm{Fd}-\mathrm{J}}=\mathrm{Fd} . \mathrm{J} . \operatorname{pref}_{\mathrm{Fd}-\mathrm{J} .} \mathrm{U}_{\max (\mathrm{J})} /\left(\mathrm{Fd}+\mathrm{h}_{\mathrm{J} \cdot}\left(\mathrm{T}_{\mathrm{s}}+\mathrm{T}_{\mathrm{d}}\right)\right)$ \\
\hline $\begin{array}{l}\text { Catch of } \\
\text { suspension/deposit } \\
\text { feeding benthos }\end{array}$ & $\Omega_{\mathrm{Bs}-\mathrm{M}}=$ Bs. $\mathrm{X}_{\mathrm{Bs}}$ \\
\hline $\begin{array}{l}\text { Catch of } \\
\text { carnivorous/scavenge } \\
\text { feeding benthos }\end{array}$ & $\Omega_{\mathrm{Bc}-\mathrm{M}}=\mathrm{Bc} . \mathrm{X}_{\mathrm{Bc}}$ \\
\hline Catch of pelagic fish & $\Omega_{\mathrm{Fp}-\mathrm{M}}=\mathrm{Fp} . \mathrm{X}_{\mathrm{Fp}}$ \\
\hline $\begin{array}{l}\text { Catch of demersal } \\
\text { fish }\end{array}$ & $\Omega_{\mathrm{Fd}-\mathrm{M}}=\mathrm{Fd} . \mathrm{X}_{\mathrm{Fd}}$ \\
\hline
\end{tabular}




\section{Table S6}

Balance equations for each state variable.

\begin{tabular}{|c|c|}
\hline Rate term & Description \\
\hline $\begin{array}{l}\text { Rate of change of } \\
\text { surface detritus (formed } \\
\text { from death of surface } \\
\text { phytoplankton). }\end{array}$ & $\begin{array}{l}\mathrm{dD}_{\mathrm{s}} / \mathrm{dt}=\mathrm{x}_{\mathrm{s}} \cdot \mathrm{P}_{\mathrm{s}}-\Omega_{\text {Ds-H }}-\mathrm{m}_{\mathrm{s}} \cdot \mathrm{D}_{\mathrm{s}}-\mathrm{x}_{\text {sink }} \mathrm{s} \cdot \mathrm{D}_{\mathrm{s}}+\mathrm{V}(\mathrm{t}) \cdot\left(\left(\mathrm{D}_{\mathrm{d}} / \mathrm{T}_{\mathrm{d}}\right)-\right. \\
\left(\mathrm{D}_{\mathrm{s}} / \mathrm{T}_{\mathrm{s}}\right) / \mathrm{T}_{\mathrm{Vsd}}(\mathrm{t})+\mathrm{I}_{\mathrm{s}}(\mathrm{t}) * \mathrm{~T}_{\mathrm{s}} *[\mathrm{D}]_{\mathrm{bs}}(\mathrm{t})+\mathrm{p}_{I d} * \mathrm{I}_{\mathrm{d}}(\mathrm{t}) * \mathrm{D}_{\mathrm{d}}- \\
\left(\mathrm{I}_{\mathrm{s}}(\mathrm{t})^{*} \mathrm{~T}_{\mathrm{s}}+\mathrm{p}_{I d} * \mathrm{I}_{\mathrm{d}}(\mathrm{t}) * \mathrm{~T}_{\mathrm{d}}+\mathrm{R}(\mathrm{t})\right)^{*} \mathrm{D}_{\mathrm{s}} / \mathrm{T}_{\mathrm{s}}\end{array}$ \\
\hline $\begin{array}{l}\text { Rate of change in deep } \\
\text { detritus (formed from } \\
\text { death of deep } \\
\text { phytoplankton, sinking } \\
\text { of detritus from the } \\
\text { surface layer, and the } \\
\text { faeces of zooplankton } \\
\text { fish and } \\
\text { birds/mammals). }\end{array}$ & $\begin{array}{l}\mathrm{dD} d / \mathrm{dt}=\left(\left(1-\mathrm{a}_{\mathrm{H}}\right) / 2\right) \cdot\left(\Omega_{\mathrm{Ps}-\mathrm{H}}+\Omega_{\mathrm{Pd}-\mathrm{H}}+\Omega_{\mathrm{Ds}-\mathrm{H}}+\Omega_{\mathrm{Dd}-\mathrm{H}}\right) \\
+\left(\left(1-\mathrm{a}_{\mathrm{C}}\right) / 2\right) \cdot\left(\Omega_{\mathrm{H}-\mathrm{C}}+\Omega_{\mathrm{FLp}-\mathrm{C}}+\Omega_{\mathrm{FLd}-\mathrm{C}}\right) \\
+\left(\left(1-\mathrm{a}_{\mathrm{FLp}}\right) / 2\right) \cdot\left(\Omega_{\mathrm{H}-\mathrm{FLp}}\right) \\
+\left(\left(1-\mathrm{a}_{\mathrm{FLd}}\right) / 2\right) \cdot\left(\Omega_{\mathrm{H}-\mathrm{FLd}}\right) \\
+\left(\left(1-\mathrm{a}_{\mathrm{Fp}}\right) / 2\right) \cdot\left(\Omega_{\mathrm{H}-\mathrm{Fp}}+\Omega_{\mathrm{C}-\mathrm{Fp}}+\Omega_{\mathrm{FLp}-\mathrm{Fp}}+\Omega_{\mathrm{FLd}-\mathrm{Fp}}\right) \\
+\left(\left(1-\mathrm{a}_{\mathrm{Fd}}\right) / 2\right) \cdot\left(\Omega_{\mathrm{C}-\mathrm{Fd}}+\Omega_{\mathrm{FLp}-\mathrm{Fd}}+\Omega_{\mathrm{FLd}-\mathrm{Fd}}+\Omega_{\mathrm{Fp}-\mathrm{Fd}}+\Omega_{\mathrm{Bs}-\mathrm{Fd}}+\right. \\
\left.\Omega_{\mathrm{Bc}-\mathrm{Fd}}+\Omega_{\mathrm{Fd}-\mathrm{Fd}}+\Omega_{\mathrm{Df}-\mathrm{Fd}}+\Omega_{\mathrm{Dc}-\mathrm{Fd}}\right) \\
+\left(\left(1-\mathrm{a}_{\mathrm{J}}\right) / 2\right) \cdot\left(\Omega_{\mathrm{Fp}-\mathrm{J}}+\Omega_{\mathrm{Fd}-\mathrm{J}}+\Omega_{\mathrm{Df}-\mathrm{J}}\right) \\
+\mathrm{x}_{\mathrm{d}} \cdot \mathrm{U}_{\mathrm{d}}+\mathrm{x}_{\mathrm{d}} \cdot \mathrm{P}_{\mathrm{d}}+\mathrm{x}_{\mathrm{sink}} \cdot \mathrm{D}_{\mathrm{s}}-\mathrm{m}_{\mathrm{d}} \cdot \mathrm{D}_{\mathrm{d}}-\mathrm{x}_{\text {sink }} \cdot \mathrm{D}_{\mathrm{d}} \\
-\Omega_{\mathrm{Dd}-\mathrm{Bs}}-\Omega_{\mathrm{Dd}-\mathrm{H}}-\mathrm{V}(\mathrm{t}) \cdot\left(\left(\mathrm{D}_{\mathrm{d}} / \mathrm{T}_{\mathrm{d}}\right)-\left(\mathrm{D}_{\mathrm{s}} / \mathrm{T}_{\mathrm{s}}\right)\right) / \mathrm{T}_{\mathrm{Vsd}}(\mathrm{t})+ \\
\mathrm{I}_{\mathrm{d}}(\mathrm{t})^{*} \mathrm{~T}_{\mathrm{d}} *[\mathrm{D}]_{\mathrm{bd}}(\mathrm{t})-\mathrm{I}_{\mathrm{d}}(\mathrm{t}) * \mathrm{D}_{\mathrm{d}}\end{array}$ \\
\hline $\begin{array}{l}\text { Rate of change in } \\
\text { sediment detritus } \\
\text { (formed from the } \\
\text { settlement of deep } \\
\text { suspended detritus, } \\
\text { faeces of benthos, and } \\
\text { corpses). }\end{array}$ & $\begin{array}{l}\mathrm{dD} / \mathrm{dt}= \\
+\left(\left(1-\mathrm{a}_{\mathrm{Bs}}\right) / 2\right) \cdot\left(\Omega_{\mathrm{Dd}-\mathrm{Bs}}+\Omega_{\mathrm{Pd}-\mathrm{Bs}}+\Omega_{\mathrm{Dx}-\mathrm{Bs}}\right) \\
+\left(\left(1-\mathrm{a}_{\mathrm{Bc}}\right) / 2\right) \cdot\left(\Omega_{\mathrm{Bs}-\mathrm{Bc}}+\Omega_{\mathrm{Dc}-\mathrm{Bc}}\right) \\
+\mathrm{x}_{\text {sink_d }} \cdot \mathrm{D}_{\mathrm{d}} \\
+\mathrm{x}_{\text {corp_sed }} \cdot \mathrm{D}_{\mathrm{c}} \\
-\mathrm{m}_{\mathrm{x}} \cdot \mathrm{D}_{\mathrm{x}}-\Omega_{\mathrm{Dx}-\mathrm{Bs}}\end{array}$ \\
\hline $\begin{array}{l}\text { Rate of change in } \\
\text { fishery discards. }\end{array}$ & $\begin{array}{l}\mathrm{dD}_{\mathrm{f}} / \mathrm{dt}= \\
+\operatorname{disc}_{\mathrm{p}} \cdot \Omega_{\mathrm{Fp}-\mathrm{M}} \\
+\exp (-\mathrm{dfd} \cdot \mathrm{Fd}) \cdot \Omega_{\mathrm{Fd}-\mathrm{M}} \\
+\operatorname{disc}_{\mathrm{Bs}} \cdot \Omega_{\mathrm{Bs}-\mathrm{M}} \\
+\operatorname{disc}_{\mathrm{Bc}} \cdot \Omega_{\mathrm{Bc}-\mathrm{M}} \\
-\mathrm{X}_{\mathrm{disc}-\text { corp }} \cdot \mathrm{D}_{\mathrm{f}} \\
-\Omega_{\mathrm{Df}-\mathrm{Fd}} \\
-\Omega_{\text {Df-J }}\end{array}$ \\
\hline $\begin{array}{l}\text { Rate of change in } \\
\text { seabed corpses. }\end{array}$ & $\begin{array}{l}\mathrm{dD} / \mathrm{dt}= \\
+\mathrm{x}_{\mathrm{disc}-\mathrm{corp}} \cdot \mathrm{D}_{\mathrm{f}} \\
-\mathrm{x}_{\mathrm{corp}-\text { sed }} \cdot \mathrm{D}_{\mathrm{c}} \\
+\mathrm{Z}_{\mathrm{C} .} \mathrm{C}^{2}+\mathrm{z}_{\mathrm{Bc}} \cdot \mathrm{Bc}^{2}+\mathrm{z}_{\mathrm{Fp}} \cdot \mathrm{Fp}^{2}+\mathrm{z}_{\mathrm{Fd} .} \mathrm{Fd}^{2}+\mathrm{z}_{\mathrm{J} .} \mathrm{J}^{2} \\
-\Omega_{\mathrm{Dc}-\mathrm{Fd}} \\
-\Omega_{\mathrm{Dc}-\mathrm{Bc}}\end{array}$ \\
\hline $\begin{array}{l}\text { Rate of change in } \\
\text { surface ammonia. }\end{array}$ & $\begin{array}{l}\mathrm{dA} / \mathrm{dt}=\mathrm{m}_{\mathrm{s}} \cdot \mathrm{D}_{\mathrm{s}} \\
+\left(\mathrm{T}_{\mathrm{s}} /\left(\mathrm{T}_{\mathrm{s}}+\mathrm{T}_{\mathrm{d}}\right)\left(\mathrm{e}_{\mathrm{H} \cdot \mathrm{H}}+\mathrm{e}_{\mathrm{C} \cdot \mathrm{C}}+\mathrm{e}_{\mathrm{FLp}} \cdot \mathrm{FLp}+\mathrm{e}_{\mathrm{FLd}} \cdot \mathrm{FLd}+\mathrm{e}_{\mathrm{Fp}} \cdot \mathrm{Fp}\right)\right. \\
+\left(\mathrm{T}_{\mathrm{s}} /\left(\mathrm{T}_{\mathrm{s}}+\mathrm{T}_{\mathrm{d}}\right)\left(\left(\left(1-\mathrm{a}_{\mathrm{Fp}}\right) / 2\right) \cdot\left(\Omega_{\mathrm{H}-\mathrm{Fp}}+\Omega_{\mathrm{C}-\mathrm{Fp}}+\Omega_{\mathrm{FL}-\mathrm{Fp}}+\Omega_{\mathrm{FLd}-}\right.\right.\right. \\
\mathrm{Fp})) \\
+\left(\mathrm{T}_{\mathrm{s}} /\left(\mathrm{T}_{\mathrm{s}}+\mathrm{T}_{\mathrm{d}}\right)\left(\left(\left(1-\mathrm{a}_{\mathrm{FLp}}\right) / 2\right) \cdot\left(\Omega_{\mathrm{H}-\mathrm{FLp}}\right)\right.\right. \\
+\left(\mathrm{T}_{\mathrm{s}} /\left(\mathrm{T}_{\mathrm{s}}+\mathrm{T}_{\mathrm{d}}\right)\left(\left(\left(1-\mathrm{a}_{\mathrm{FLd}}\right) / 2\right) \cdot\left(\Omega_{\mathrm{H}-\mathrm{FLd}}\right)\right.\right. \\
+\left(\mathrm{T}_{\mathrm{s}} /\left(\mathrm{T}_{\mathrm{s}}+\mathrm{T}_{\mathrm{d}}\right)\left(\left(\left(1-\mathrm{a}_{\mathrm{C}}\right) / 2\right) \cdot\left(\Omega_{\mathrm{H}-\mathrm{C}}+\Omega_{\mathrm{FLp}-\mathrm{C}}+\Omega_{\mathrm{FLd}-\mathrm{C}}\right)\right)\right. \\
+\left(\left(1-\mathrm{a}_{\mathrm{H}}\right) / 2\right) \cdot\left(\Omega_{\mathrm{Ps}-\mathrm{H}}+\Omega_{\mathrm{Ds}-\mathrm{H}}\right) \\
+\left(\left(1-\mathrm{a}_{\mathrm{J}}\right) / 2\right) \cdot\left(\Omega_{\mathrm{Fp}-\mathrm{J}}+\Omega_{\mathrm{Fd}-\mathrm{J}}+\Omega_{\mathrm{Df}-\mathrm{J}}\right) \\
+\mathrm{e}_{\mathrm{J} .} \mathrm{J}\end{array}$ \\
\hline
\end{tabular}




\begin{tabular}{|c|c|}
\hline & $\begin{array}{l}-\mathrm{n}_{\mathrm{s}} \cdot \mathrm{A}_{\mathrm{s}}-\Omega_{\mathrm{As}-\mathrm{Us}}-\Omega_{\mathrm{As}-\mathrm{Ps}}+\mathrm{V}(\mathrm{t}) \cdot\left(\left(\mathrm{A}_{\mathrm{d}} / \mathrm{T}_{\mathrm{d}}\right)-\left(\mathrm{A}_{\mathrm{s}} / \mathrm{T}_{\mathrm{s}}\right)\right) / \mathrm{T}_{\mathrm{Vsd}}(\mathrm{t}) \\
+\mathrm{I}_{\mathrm{s}}(\mathrm{t}) * \mathrm{~T}_{\mathrm{s}} *[\mathrm{~A}]_{\mathrm{bs}}(\mathrm{t})+\mathrm{p}_{\mathrm{Id}} * \mathrm{I}_{\mathrm{d}}(\mathrm{t}) * \mathrm{~A}_{\mathrm{d}}+\mathrm{R}(\mathrm{t}) * \mathrm{~T}_{\mathrm{s}} *[\mathrm{~N}]_{\mathrm{R}}(\mathrm{t}) \\
+[\mathrm{N}]_{\mathrm{A}}(\mathrm{t}) \\
-\left(\mathrm{I}_{\mathrm{s}}(\mathrm{t}) * \mathrm{~T}_{\mathrm{s}}+\mathrm{p}_{\mathrm{Id}} * \mathrm{I}_{\mathrm{d}}(\mathrm{t}) * \mathrm{~T}_{\mathrm{d}}+\mathrm{R}(\mathrm{t})\right)^{*} \mathrm{~A}_{\mathrm{s}} / \mathrm{T}_{\mathrm{s}}\end{array}$ \\
\hline $\begin{array}{l}\text { Rate of change in deep } \\
\text { ammonia. }\end{array}$ & $\begin{array}{l}\mathrm{dA} d \mathrm{~d} / \mathrm{dt}=\mathrm{m}_{\mathrm{d} \cdot} \cdot \mathrm{D}_{\mathrm{d}} \\
+\left(\mathrm{T}_{\mathrm{d}} /\left(\mathrm{T}_{\mathrm{s}}+\mathrm{T}_{\mathrm{d}}\right)\left(\mathrm{e}_{\mathrm{H}} \cdot \mathrm{H}+\mathrm{e}_{\mathrm{C}} \cdot \mathrm{C}+\mathrm{e}_{\mathrm{Fp}} \cdot \mathrm{Fp}\right)\right. \\
+\mathrm{e}_{\mathrm{Bs}} \cdot \mathrm{Bs}+\mathrm{e}_{\mathrm{Bc}} \cdot \mathrm{Bc}+\mathrm{e}_{\mathrm{Fd}} \cdot \mathrm{Fd} \\
+\left(\mathrm{T}_{\mathrm{d}} /\left(\mathrm{T}_{\mathrm{s}}+\mathrm{T}_{\mathrm{d}}\right)\left(\left(\left(1-\mathrm{a}_{\mathrm{FLp}}\right) / 2\right) \cdot\left(\Omega_{\mathrm{H}-\mathrm{FLp}}\right)\right.\right. \\
+\left(\mathrm{T}_{\mathrm{d}} /\left(\mathrm{T}_{\mathrm{s}}+\mathrm{T}_{\mathrm{d}}\right)\left(\left(\left(1-\mathrm{a}_{\mathrm{FLd}}\right) / 2\right) \cdot\left(\Omega_{\mathrm{H}-\mathrm{FLd}}\right)\right.\right. \\
+\left(\mathrm{T}_{\mathrm{d}} /\left(\mathrm{T}_{\mathrm{s}}+\mathrm{T}_{\mathrm{d}}\right)\left(\left(\left(1-\mathrm{a}_{\mathrm{Fp}}\right) / 2\right) \cdot\left(\Omega_{\mathrm{H}-\mathrm{Fp}}+\Omega_{\mathrm{C}-\mathrm{Fp}}+\Omega_{\mathrm{Fd}-\mathrm{Fp}}\right)\right)\right. \\
+\left(\left(\left(1-\mathrm{a}_{\mathrm{Fd}}\right) / 2\right) \cdot\left(\Omega_{\mathrm{C}-\mathrm{Fd}}+\Omega_{\mathrm{FLp}-\mathrm{Fd}}+\Omega_{\mathrm{FLd}-\mathrm{Fd}}+\Omega_{\mathrm{Fp}-\mathrm{Fd}}+\Omega_{\mathrm{Bs}-\mathrm{Fd}}+\right.\right. \\
\left.\left.\Omega_{\mathrm{Bd}-\mathrm{Fd}}+\Omega_{\mathrm{Bc}-\mathrm{Fd}+}+\Omega_{\mathrm{Fd}-\mathrm{Fd}}+\Omega_{\mathrm{Df}-\mathrm{Fd}}+\Omega_{\mathrm{Dc}-\mathrm{Fd}}\right)\right) \\
+\left(\mathrm{T}_{\mathrm{d}} /\left(\mathrm{T}_{\mathrm{s}}+\mathrm{T}_{\mathrm{d}}\right)\left(\left(\left(1-\mathrm{a}_{\mathrm{C}}\right) / 2\right) \cdot\left(\Omega_{\mathrm{H}-\mathrm{C}}+\Omega_{\mathrm{FLp}-\mathrm{C}}+\Omega_{\mathrm{FLd}-\mathrm{C}}\right)\right)\right. \\
+\left(\left(1-\mathrm{a}_{\mathrm{H}}\right) / 2\right) \cdot\left(\Omega_{\mathrm{Dd}-\mathrm{H}}+\Omega_{\mathrm{Pd}-\mathrm{H}}\right) \\
+\left(\left(1-\mathrm{a}_{\mathrm{Bg}}\right) / 2\right) \cdot\left(\Omega_{\mathrm{Dd}-\mathrm{Bs}}+\Omega_{\mathrm{Dx}-\mathrm{Bs}}+\Omega_{\mathrm{Pd}-\mathrm{Bs}}\right) \\
+\left(\left(1-\mathrm{a}_{\mathrm{Bc}}\right) / 2\right) \cdot\left(\Omega_{\mathrm{Bs}-\mathrm{Bc}}+\Omega_{\mathrm{Dc}-\mathrm{Bc}}\right) \\
+\mathrm{V}_{\mathrm{x}} \cdot\left(\left(\mathrm{A}_{\mathrm{x}} /\left(\mathrm{T}_{\mathrm{x}} \cdot \mathrm{por} \mathrm{x}\right)\right)-\left(\mathrm{A}_{\mathrm{d}} / \mathrm{T}_{\mathrm{d}}\right)\right) / \mathrm{T}_{\mathrm{Vx}} \\
-\mathrm{n}_{\mathrm{d}} \cdot \mathrm{A}_{\mathrm{d}}-\mathrm{V}(\mathrm{t}) \cdot\left(\left(\mathrm{A}_{\mathrm{d}} / \mathrm{T}_{\mathrm{d}}\right)-\left(\mathrm{A}_{\mathrm{s}} / \mathrm{T}_{\mathrm{S}}\right)\right) / \mathrm{T}_{\mathrm{Vsd}}(\mathrm{t}) \\
+\mathrm{I}_{\mathrm{d}}(\mathrm{t}) * \mathrm{~T}_{\mathrm{d}} *[\mathrm{~A}]_{\mathrm{bd}}(\mathrm{t})-\mathrm{I}_{\mathrm{d}}(\mathrm{t}) * \mathrm{~A}_{\mathrm{d}}\end{array}$ \\
\hline $\begin{array}{l}\text { Rate of change in } \\
\text { sediment ammonia. }\end{array}$ & $d A_{x} / d t=m_{x} \cdot D_{x}-n_{x} \cdot A_{x}-V_{x} \cdot\left(\left(A_{x} /\left(T_{x} \cdot p_{x}\right)\right)-\left(A_{d} / T_{d}\right)\right) / T_{V x}$ \\
\hline $\begin{array}{l}\text { Rate of change in } \\
\text { surface nitrate }\end{array}$ & $\begin{array}{l}\mathrm{dN}_{\mathrm{s}} / \mathrm{dt}=\mathrm{n}_{\mathrm{s}} \cdot \mathrm{A}_{\mathrm{s}}-\Omega_{\mathrm{Ns}-\mathrm{Ps}}-\Omega_{\mathrm{Ns}-\mathrm{Us}}-\mathrm{d}_{\mathrm{s}} \cdot \mathrm{N}_{\mathrm{s}}+\mathrm{V}(\mathrm{t}) \cdot\left(\left(\mathrm{N}_{\mathrm{d}} / \mathrm{T}_{\mathrm{d}}\right)-\right. \\
\left.\left(\mathrm{N}_{\mathrm{s}} / \mathrm{T}_{\mathrm{s}}\right)\right) / \mathrm{T}_{\mathrm{Vsd}}(\mathrm{t})+\mathrm{R}(\mathrm{t}) * \mathrm{~T}_{\mathrm{s}} *[\mathrm{~N}]_{\mathrm{R}}(\mathrm{t})+[\mathrm{N}]_{\mathrm{A}}(\mathrm{t}) \\
+\mathrm{I}_{\mathrm{s}}(\mathrm{t}) * \mathrm{~T}_{\mathrm{s}} *[\mathrm{~N}]_{\mathrm{bs}}(\mathrm{t})+\mathrm{p}_{\mathrm{Id}} * \mathrm{I}_{\mathrm{d}}(\mathrm{t}) * \mathrm{~N}_{\mathrm{d}} \\
-\left(\mathrm{I}_{\mathrm{s}}(\mathrm{t}) * \mathrm{~T}_{\mathrm{s}}+\mathrm{p}_{\mathrm{Id}} * \mathrm{I}_{\mathrm{d}}(\mathrm{t}) * \mathrm{~T}_{\mathrm{d}}+\mathrm{R}(\mathrm{t})\right)^{*} \mathrm{~N}_{\mathrm{s}} / \mathrm{T}_{\mathrm{s}}\end{array}$ \\
\hline $\begin{array}{l}\text { Rate of change in deep } \\
\text { nitrate. }\end{array}$ & $\begin{array}{l}d N_{d} / d t=n_{d} \cdot A_{d}-d_{d} \cdot N_{d}-V(t) \cdot\left(\left(N_{d} / T_{d}\right)-\left(N_{s} / T_{s}\right)\right) / T_{V s d}(t) \\
+V_{x} \cdot\left(\left(N_{x} /\left(T_{x} \cdot p_{0} r_{x}\right)\right)-\left(N_{d} / T_{d}\right)\right) / T_{V x} \\
+I_{d}(t) * T_{d} *[N]_{b d}(t)-I_{d}(t) * N_{d}\end{array}$ \\
\hline $\begin{array}{l}\text { Rate of change in } \\
\text { sediment nitrate. }\end{array}$ & $d N_{x} / d t=n_{x} \cdot A_{x}-d_{x} \cdot N_{x}-V_{x} \cdot\left(\left(N_{x} /\left(T_{x} \cdot p_{x}\right)\right)-\left(N_{d} / T_{d}\right)\right) / T_{V x}$ \\
\hline $\begin{array}{l}\text { Rate of change in } \\
\text { surface phytoplankton. }\end{array}$ & $\begin{array}{l}\mathrm{dP}_{\mathrm{s}} / \mathrm{dt}=\Omega_{\mathrm{As}-\mathrm{Ps}}+\Omega_{\mathrm{Ns}-\mathrm{Ps}}-\mathrm{x}_{\mathrm{s}} \cdot \mathrm{P}_{\mathrm{s}}-\Omega_{\mathrm{Ps}-\mathrm{H}}+\mathrm{V}(\mathrm{t}) \cdot\left(\left(\mathrm{P}_{\mathrm{d}} / \mathrm{T}_{\mathrm{d}}\right)-\right. \\
\left.\left(\mathrm{P}_{\mathrm{s}} / \mathrm{T}_{\mathrm{s}}\right)\right) / \mathrm{T}_{\mathrm{Vsd}}(\mathrm{t}) \\
+\mathrm{I}_{\mathrm{s}}(\mathrm{t}) * \mathrm{~T}_{\mathrm{s}} *[\mathrm{P}]_{\mathrm{bs}}(\mathrm{t})+\mathrm{p}_{\mathrm{II}} * \mathrm{I}_{\mathrm{d}}(\mathrm{t}) * \mathrm{P}_{\mathrm{d}} \\
-\left(\mathrm{I}_{\mathrm{s}}(\mathrm{t}) * \mathrm{~T}_{\mathrm{s}}+\mathrm{p}_{\mathrm{Id}} * \mathrm{I}_{\mathrm{d}}(\mathrm{t}) * \mathrm{~T}_{\mathrm{d}}+\mathrm{R}(\mathrm{t})\right)^{*} \mathrm{P}_{\mathrm{s}} / \mathrm{T}_{\mathrm{s}}\end{array}$ \\
\hline $\begin{array}{l}\text { Rate of change in deep } \\
\text { phytoplankton. }\end{array}$ & $\begin{array}{l}\mathrm{dP}_{\mathrm{s}} / \mathrm{dt}=-\mathrm{x}_{\mathrm{d}} \cdot \mathrm{P}_{\mathrm{d}}-\Omega_{\mathrm{Pd}-\mathrm{H}}-\Omega_{\mathrm{Pd}-\mathrm{Bs}}-\mathrm{V}(\mathrm{t}) \cdot\left(\left(\mathrm{P}_{\mathrm{d}} / \mathrm{T}_{\mathrm{d}}\right)-\left(\mathrm{P}_{\mathrm{s}} / \mathrm{T}_{\mathrm{s}}\right)\right) / \\
\mathrm{T}_{\mathrm{Vsd}}(\mathrm{t})+\mathrm{I}_{\mathrm{d}}(\mathrm{t}) * \mathrm{~T}_{\mathrm{d}} *[\mathrm{P}]_{\mathrm{bd}}(\mathrm{t})-\mathrm{I}_{\mathrm{d}}(\mathrm{t}) * \mathrm{P}_{\mathrm{d}}\end{array}$ \\
\hline $\begin{array}{l}\text { Rate of change in } \\
\text { herbivorous } \\
\text { zooplankton. }\end{array}$ & $\begin{array}{l}\mathrm{dH} / \mathrm{dt}=\mathrm{a}_{\mathrm{H}} \cdot\left(\Omega_{\mathrm{Ds}-\mathrm{H}}+\Omega_{\mathrm{Ps}-\mathrm{H}}+\Omega_{\mathrm{Dd}-\mathrm{H}}+\Omega_{\mathrm{Pd}-\mathrm{H}}\right)-\mathrm{e}_{\mathrm{H}} \cdot \mathrm{H}-\Omega_{\mathrm{H}-\mathrm{C}}- \\
\Omega_{\mathrm{H}-\mathrm{FLp}}-\Omega_{\mathrm{H}-\mathrm{FLd}}-\Omega_{\mathrm{H}-\mathrm{Fp}}\end{array}$ \\
\hline $\begin{array}{l}\text { Rate of change in } \\
\text { carnivorous } \\
\text { zooplankton. }\end{array}$ & $\begin{array}{l}\mathrm{dC} / \mathrm{dt}=\mathrm{a}_{\mathrm{C} \cdot}\left(\Omega_{\mathrm{H}-\mathrm{C}}+\Omega_{\mathrm{FLp}-\mathrm{C}}+\Omega_{\mathrm{FLd}-\mathrm{C}}\right)-\mathrm{e}_{\mathrm{C}} \cdot \mathrm{C}-\Omega_{\mathrm{C}-\mathrm{Fd}}-\Omega_{\mathrm{C}-\mathrm{Fp}}- \\
\mathrm{z}_{\mathrm{C}} \cdot \mathrm{C}^{2}\end{array}$ \\
\hline $\begin{array}{l}\text { Rate of change in } \\
\text { suspension/deposit } \\
\text { feeding benthos. }\end{array}$ & $\begin{array}{l}\mathrm{dBs} / \mathrm{dt}=\mathrm{a}_{\mathrm{Bs}}\left(\Omega_{\mathrm{Pd}-\mathrm{Bs}}+\Omega_{\mathrm{Dd}-\mathrm{Bs}}+\Omega_{\mathrm{Dx}-\mathrm{Bs}}\right)-\mathrm{e}_{\mathrm{Bs}} \cdot \mathrm{Bs}-\Omega_{\mathrm{Bs}-\mathrm{Bc}}- \\
\Omega_{\mathrm{Bs}-\mathrm{Fd}}-\Omega_{\mathrm{Bs}-\mathrm{M}}\end{array}$ \\
\hline $\begin{array}{l}\text { Rate of change in } \\
\text { carnivore/scavenge } \\
\text { feeding benthos. }\end{array}$ & $\begin{array}{l}\mathrm{dBc} / \mathrm{dt}=\mathrm{a}_{\mathrm{Bc} \cdot}\left(\Omega_{\mathrm{Bs}-\mathrm{Bc}}+\Omega_{\mathrm{Dc}-\mathrm{Bc}}\right)-\mathrm{e}_{\mathrm{Bc}} \cdot \mathrm{Bc}-\Omega_{\mathrm{Bc}-\mathrm{Fd}}-\Omega_{\mathrm{Bc}-\mathrm{M}}- \\
\mathrm{Z}_{\mathrm{Bc} \cdot} \cdot \mathrm{Bc}^{2}\end{array}$ \\
\hline $\begin{array}{l}\text { Rate of change in } \\
\text { pelagic fish larvae. }\end{array}$ & $\begin{array}{l}\mathrm{dFLp} / \mathrm{dt}=\mathrm{a}_{\mathrm{FLp}} \cdot\left(\Omega_{\mathrm{H}-\mathrm{FLp}}\right)-\mathrm{e}_{\mathrm{FLp}} \cdot \mathrm{FLp}-\Omega_{\mathrm{FLp}-\mathrm{C}}-\Omega_{\mathrm{FLp}-\mathrm{Fp}}- \\
\Omega_{\mathrm{FLp}-\mathrm{Fd}}+\operatorname{Pspn}(\mathrm{t}) * \mathrm{~F}_{\mathrm{p}}-\operatorname{Prec}(\mathrm{t}) * \mathrm{FL}_{\mathrm{p}}\end{array}$ \\
\hline
\end{tabular}




\begin{tabular}{|c|c|}
\hline $\begin{array}{l}\text { Rate of change in } \\
\text { demersal fish larvae. }\end{array}$ & $\begin{array}{l}\mathrm{dFLd} / \mathrm{dt}=\mathrm{a}_{\mathrm{FLd}} \cdot\left(\Omega_{\mathrm{H}-\mathrm{FLd}}\right)-\mathrm{e}_{\mathrm{FLd}} \cdot \mathrm{FLd}-\Omega_{\mathrm{FLd}-\mathrm{C}}-\Omega_{\mathrm{FLd}-\mathrm{Fp}}- \\
\Omega_{\mathrm{FLd}-\mathrm{Fd}}+\operatorname{Dspn}(\mathrm{t}) * \mathrm{~F}_{\mathrm{d}}-\operatorname{Drec}(\mathrm{t}) * \mathrm{FL}_{\mathrm{d}}\end{array}$ \\
\hline $\begin{array}{l}\text { Rate of change in } \\
\text { pelagic fish. }\end{array}$ & $\begin{array}{l}\mathrm{dFp} / \mathrm{dt}=\mathrm{a}_{\mathrm{Fp}} \cdot\left(\Omega_{\mathrm{C}-\mathrm{Fp}}+\Omega_{\mathrm{H}-\mathrm{Fp}}+\Omega_{\mathrm{FLp}-\mathrm{Fp}}+\Omega_{\mathrm{FLd}-\mathrm{Fp}}\right)-\mathrm{e}_{\mathrm{Fp}} \cdot \mathrm{Fp}- \\
\Omega_{\mathrm{Fp}-\mathrm{Fd}}-\Omega_{\mathrm{Fp}-\mathrm{M}}-\Omega_{\mathrm{Fp}-\mathrm{J}}-\mathrm{Z}_{\mathrm{Fp}} \cdot \mathrm{Fp}^{2}-\operatorname{Pspn}(\mathrm{t}) * \mathrm{~F}_{\mathrm{p}}+\operatorname{Prec}(\mathrm{t}) * \\
\mathrm{FL}_{\mathrm{p}}\end{array}$ \\
\hline $\begin{array}{l}\text { Rate of change in } \\
\text { demersal fish. }\end{array}$ & $\begin{array}{l}\mathrm{dFd} / \mathrm{dt}=\mathrm{a}_{\mathrm{Fd} \cdot} \cdot\left(\Omega_{\mathrm{Bs}-\mathrm{Fd}}+\Omega_{\mathrm{Bd}-\mathrm{Fd}}+\Omega_{\mathrm{Bc}-\mathrm{Fd}}+\Omega_{\mathrm{C}-\mathrm{Fd}}+\Omega_{\mathrm{FLp}-\mathrm{Fd}}+\right. \\
\left.\Omega_{\mathrm{FLd}-\mathrm{Fd}}+\Omega_{\mathrm{Fp}-\mathrm{Fd}}+\Omega_{\mathrm{Fd}-\mathrm{Fd}}+\Omega_{\mathrm{Df}-\mathrm{Fd}}+\Omega_{\mathrm{Dc}-\mathrm{Fd}}\right)-\mathrm{e}_{\mathrm{Fd}} \cdot \mathrm{Fd}-\Omega_{\mathrm{Fd}-\mathrm{M}}- \\
\Omega_{\mathrm{Fd}-\mathrm{J}}-\mathrm{Z}_{\mathrm{Fd}} \cdot \mathrm{Fd}^{2}-\operatorname{Dspn}(\mathrm{t}) \cdot \mathrm{F}_{\mathrm{d}}+\operatorname{Drec}(\mathrm{t}) \cdot \mathrm{FL}_{\mathrm{d}}\end{array}$ \\
\hline $\begin{array}{l}\text { Rate of change in } \\
\text { birds/mammals. }\end{array}$ & $\mathrm{dJ} / \mathrm{dt}=\mathrm{aJ} .\left(\Omega_{\mathrm{Fp}-\mathrm{J}}+\Omega_{\mathrm{Fd}-\mathrm{J}}+\Omega_{\mathrm{Df}-\mathrm{J}}\right)-\mathrm{e}_{\mathrm{J} .} \mathrm{J}-\mathrm{Z}_{\mathrm{J} .} \mathrm{J}^{2}$ \\
\hline
\end{tabular}


Table S7

Derived properties of the model.

\begin{tabular}{|c|c|}
\hline Property & Description \\
\hline $\begin{array}{l}\text { Total annual } \\
\text { primary } \\
\text { production }\end{array}$ & $\mathrm{T}=\sum_{d a y 0}^{\operatorname{day} 360}\left(\Omega_{A s-P s}+\Omega_{N s-P s}\right)$ \\
\hline Annual MMP & $\tau=\max _{\text {day } 0}^{\operatorname{day} 360}\left(N_{s}+N_{d}\right)-\min _{\text {day } 0}^{\operatorname{day} 360}\left(N_{s}+N_{d}\right)$ \\
\hline Annual PNP & $\tau p_{N}=\sum_{\text {day } 0}^{\operatorname{day} 360}\left(\Omega_{N s-P s}+d \cdot N_{s}-n \cdot A_{s}\right)$ \\
\hline Annual MMIP & $\left.\tau i_{N}=\tau+\sum_{\text {day } 90}^{\operatorname{day} 270} R(t)+I_{s}(t) * T_{s} *\left([N]_{b s}+[A]_{b s}\right)+I_{d}(t) *\left(N_{d}+A_{d}\right)\right)$ \\
\hline $\begin{array}{l}\text { Annual vertical } \\
\text { nitrate flux }\end{array}$ & $\left.\mathrm{Vf}_{\mathrm{N}}=\sum_{\text {day } 0}^{\text {day } 360}\left(\mathrm{~V}(\mathrm{t}) \cdot\left(\left(\mathrm{N}_{\mathrm{d}} / \mathrm{T}_{\mathrm{d}}\right)-\left(\mathrm{N}_{\mathrm{s}} / \mathrm{T}_{\mathrm{s}}\right)\right) / \mathrm{T}_{\mathrm{Vsd}(\mathrm{t}}\right)+\mathrm{I}_{\mathrm{d}}(\mathrm{t}) * \mathrm{~N}_{\mathrm{d}}\right)$ \\
\hline $\begin{array}{l}\text { Annual } \\
\text { horizontal nitrate } \\
\text { flux in the } \\
\text { surface layer }\end{array}$ & $H f_{N}=\sum_{\operatorname{day} 0}^{\operatorname{day} 360}\left(\left(\mathrm{I}_{\mathrm{s}}(\mathrm{t}) * \mathrm{~T}_{\mathrm{s}} *[\mathrm{~N}]_{\mathrm{bs}}\right)-\left(\mathrm{I}_{\mathrm{s}}(\mathrm{t}) * \mathrm{~T}_{\mathrm{s}}+\mathrm{I}_{\mathrm{d}}(\mathrm{t}) * \mathrm{~T}_{\mathrm{d}}\right) * \mathrm{~N}_{\mathrm{s}} / \mathrm{T}_{\mathrm{s}}\right)$ \\
\hline $\begin{array}{l}\text { Total annual } \\
\text { nitrate uptake }\end{array}$ & $T_{N}=\sum_{\text {day } 0}^{\operatorname{day} 360}\left(\Omega_{N s-P s}\right)$ \\
\hline Annual f-ratio & $f=\tau p / T$ \\
\hline $\begin{array}{l}\text { Annual } \\
\text { mesozooplankton } \\
\text { gross production }\end{array}$ & $\gamma=\sum_{\text {day } 0}^{\operatorname{day} 360}\left(\mathrm{a}_{\mathrm{H}}\left(\Omega_{D s-H}+\Omega_{P s-H}+\Omega_{D d-H}+\Omega_{P d-H}\right)\right)$ \\
\hline
\end{tabular}




\begin{tabular}{|c|c|}
\hline $\begin{array}{l}\text { Annual } \\
\text { carnivorous } \\
\text { zooplankton } \\
\text { gross production }\end{array}$ & $\chi=\sum_{\text {day } 0}^{\operatorname{day} 360}\left(\mathrm{a}_{\mathrm{C}} \cdot\left(\Omega_{H-C}+\Omega_{F L p-C}+\Omega_{F L d-C}\right)\right.$ \\
\hline $\begin{array}{l}\text { Annual benthos } \\
\text { gross production }\end{array}$ & $\beta=\sum_{d a y 0}^{\operatorname{day} 360}\left(\mathrm{a}_{\mathrm{B}} \cdot\left(\Omega_{P d-B s}+\Omega_{D d-B s}+\Omega_{D x-B s}+\Omega_{B s-B c}\right)\right)$ \\
\hline $\begin{array}{l}\text { Annual demersal } \\
\text { fish gross } \\
\text { production }\end{array}$ & $\phi d=\sum_{d a y 0}^{d a y 360}\left(\mathrm{a}_{\mathrm{Fd}}\left(\Omega_{C-F d}+\Omega_{B s-F d}+\Omega_{B c-F d}+\Omega_{F p-F d}+\Omega_{F L p-F d}+\Omega_{F L d-F d}+\Omega_{F d-F d}+\Omega_{D f-F d}+\Omega_{D c F d}\right)\right)$ \\
\hline $\begin{array}{l}\text { Annual pelagic } \\
\text { fish gross } \\
\text { production }\end{array}$ & $\phi p=\sum_{\text {day } 0}^{\operatorname{day} 360}\left(\mathrm{a}_{\mathrm{Fp}} .\left(\Omega_{H-F p}+\Omega_{C-F p}+\Omega_{F L p-F p}+\Omega_{F L d-F p}\right)\right)$ \\
\hline $\begin{array}{l}\text { Annual demersal } \\
\text { fish larvae gross } \\
\text { production }\end{array}$ & $\left.\phi L d=\sum_{\text {day } 0}^{\operatorname{day} 360} \mathrm{a}_{\mathrm{FLd}} \cdot\left(\Omega_{H-F L d}\right)\right)$ \\
\hline $\begin{array}{l}\text { Annual pelagic } \\
\text { fish larvae gross } \\
\text { production }\end{array}$ & $\phi L p=\sum_{\text {day } 0}^{\operatorname{day} 360}\left(\mathrm{a}_{\mathrm{FLp}} \cdot\left(\Omega_{H-F L p}\right)\right)$ \\
\hline $\begin{array}{l}\text { Annual } \\
\text { bird/mammal } \\
\text { gross production }\end{array}$ & $\Pi=\sum_{\operatorname{day} 0}^{\operatorname{day} 360}\left(\mathrm{a}_{\mathrm{J}} \cdot\left(\Omega_{F p-J}+\Omega_{F d-J}+\Omega_{D f-J}\right)\right)$ \\
\hline $\begin{array}{l}\text { Pelagic fish } \\
\text { annual egg } \\
\text { production }\end{array}$ & $\sum_{d a y 0}^{\operatorname{day} 360}(\operatorname{Pspn}(\mathrm{t}) . \mathrm{Fp})$ \\
\hline $\begin{array}{l}\text { Pelagic fish } \\
\text { annual } \\
\text { recruitment }\end{array}$ & $\sum_{d a y 0}^{\operatorname{day} 360}(\operatorname{Prec}(\mathrm{t}) . \mathrm{FLp})$ \\
\hline
\end{tabular}




\begin{tabular}{|c|c|}
\hline $\begin{array}{l}\text { Demersal fish } \\
\text { annual egg } \\
\text { production }\end{array}$ & $\sum_{d a y 0}^{d a y 360}(\operatorname{Dspn}(\mathrm{t}) . \mathrm{Fd})$ \\
\hline $\begin{array}{l}\text { Demersal fish } \\
\text { annual } \\
\text { recruitment }\end{array}$ & $\sum_{d a y 0}^{\operatorname{day} 360}(\operatorname{Drec}(\mathrm{t}) . \mathrm{FLd})$ \\
\hline $\begin{array}{l}\text { Total export } \\
\text { from secondary } \\
\text { producers }\end{array}$ & $\sum_{\text {day } 0}^{\operatorname{day} 360}\left(\Omega_{\mathrm{H}-\mathrm{C}}+\Omega_{\mathrm{H}-\mathrm{FLp}}+\Omega_{\mathrm{H}-\mathrm{Fld}}+\Omega_{\mathrm{H}-\mathrm{Fp}}+\Omega_{\mathrm{Bs}-\mathrm{Bc}}+\Omega_{\mathrm{Bs}-\mathrm{Fd}}\right)$ \\
\hline $\begin{array}{l}\text { Total animal } \\
\text { production }\end{array}$ & $\Psi+\gamma+\chi+\beta+\phi L p+\phi L d+\phi p+\phi d+\Pi$ \\
\hline Fishery landings & $\sum_{d a y 0}^{\operatorname{day} 360}\left(\left(1-\operatorname{disc}_{F p}\right) \cdot \Omega_{F p-M}+(1-\exp (-d f d \cdot F d)) \cdot \Omega_{F d-M}+\left(1-d i s c_{B s}\right) \cdot \Omega_{B s-M}+\left(1-d i s c_{B c}\right) \cdot \Omega_{B c-M}\right)$ \\
\hline $\begin{array}{l}\text { Total annual } \\
\text { water column } \\
\text { mineralization } \\
\text { flux }\end{array}$ & $\sum_{\text {day } 0}^{\operatorname{day} 360}\left(\mathrm{~m}_{\mathrm{s}} \cdot \mathrm{D}_{\mathrm{s}}+\mathrm{m}_{\mathrm{d}} \cdot \mathrm{D}_{\mathrm{d}}\right)$ \\
\hline $\begin{array}{l}\text { Total annual } \\
\text { sediment } \\
\text { mineralization } \\
\text { flux }\end{array}$ & $\sum_{\text {day } 0}^{\operatorname{day} 360} \mathrm{~m}_{\mathrm{x}} \cdot \mathrm{D}_{\mathrm{x}}$ \\
\hline $\begin{array}{l}\text { Total annual } \\
\text { denitrification } \\
\text { flux }\end{array}$ & $\sum_{\text {day } 0}^{\operatorname{day} 360}\left(\mathrm{~d}_{\mathrm{s}} \cdot \mathrm{N}_{\mathrm{s}}+\mathrm{d}_{\mathrm{d}} \cdot \mathrm{N}_{\mathrm{d}}\right)$ \\
\hline $\begin{array}{l}\text { Total annual } \\
\text { nitrification flux }\end{array}$ & $\sum_{\text {day } 0}^{\operatorname{day} 360}\left(\mathrm{n}_{\mathrm{s}} \cdot \mathrm{A}_{\mathrm{s}}+\mathrm{n}_{\mathrm{d}} \cdot \mathrm{A}_{\mathrm{d}}+n_{x} \cdot A_{x}\right)$ \\
\hline
\end{tabular}




\begin{tabular}{|c|c|}
\hline $\begin{array}{l}\text { Total annual } \\
\text { sediment-water } \\
\text { ammonia flux }\end{array}$ & $\begin{array}{l}\sum_{d a y 0}^{\operatorname{day} 360}\left(\mathrm{~V}_{\mathrm{x} .} \mathrm{T}_{\mathrm{Vx}} \cdot\left(\left(\mathrm{A}_{\mathrm{x}} /\left(\mathrm{T}_{\mathrm{x}} \cdot \mathrm{por}_{\mathrm{x}}\right)\right)-\left(\mathrm{A}_{\mathrm{d}} / \mathrm{T}_{\mathrm{d}}\right)\right)\right)+\sum_{d a y 0}^{\operatorname{day} 360}\left(\left(\left(1-\mathrm{a}_{\mathrm{Bs}}\right) / 2\right) \cdot\left(\Omega_{D d-B s}+\Omega_{D x-B s}+\Omega_{P d-B s}\right)\right)+ \\
\sum_{\operatorname{day} 0}^{\operatorname{day} 360}\left(\left(\left(1-\mathrm{a}_{\mathrm{Bc}}\right) / 2\right) \cdot\left(\Omega_{B s-B c}+\Omega_{D c-B c}\right)\right)\end{array}$ \\
\hline $\begin{array}{l}\text { Total annual } \\
\text { sediment-water } \\
\text { nitrate flux }\end{array}$ & $\sum_{\operatorname{day} 0}^{\operatorname{day} 360}\left(\mathrm{~V}_{\mathrm{x}} \mathrm{T}_{\mathrm{Vx}} \cdot\left(\left(\mathrm{N}_{\mathrm{x}} /\left(\mathrm{T}_{\mathrm{x}} \cdot \operatorname{por}_{\mathrm{x}}\right)\right)-\left(\mathrm{N}_{\mathrm{d}} / \mathrm{T}_{\mathrm{d}}\right)\right)\right)$ \\
\hline $\begin{array}{l}\text { Total annual } \\
\text { particulate flux } \\
\text { from water } \\
\text { column to the } \\
\text { sediment }\end{array}$ & $\sum_{\text {day } 0}^{d a y 360}\left(\Omega_{P d-B s}+\Omega_{D d-B s}+x_{\text {disc-corp }} . D_{f}+x_{\sin k_{-} d} . D_{d}\right)$ \\
\hline $\begin{array}{l}\text { Total annual flux } \\
\text { of fishery } \\
\text { discards to the } \\
\text { sediment }\end{array}$ & $\sum_{d a y 0}^{d a y 360}\left(\mathrm{x}_{\text {disc-corp }} \cdot \mathrm{D}_{\mathrm{f}}\right)$ \\
\hline $\begin{array}{l}\text { Total mass of } \\
\text { nitrogen }\end{array}$ & $\begin{array}{l}D_{s}+D_{d}+D_{x}+D_{f}+D_{c}+A_{s}+A_{d}+N_{s}+N_{d}+P_{s}+P_{d}+H+C+B s+B c+F L p+F L d+F p \\
+F d+J\end{array}$ \\
\hline
\end{tabular}




\section{Table S8}

Metabolic parameters for all living components of the model. These parameters were fixed and not subject to fitting by the simulated annealing process.

\begin{tabular}{|c|c|c|c|c|}
\hline Predator & $\begin{array}{c}\mathrm{Q}_{10} \text { for } \\
\text { uptake rates }\end{array}$ & $\begin{array}{l}\text { Proportion of } \\
\text { uptake } \\
\text { converted to } \\
\text { biomass }\left(a_{x},\right. \\
\left.d^{-1}\right)\end{array}$ & $\begin{array}{c}\text { Background } \\
\text { proportion of } \\
\text { biomass excreted } \\
\text { as ammonia }\left(\mathrm{e}_{\mathrm{x}},\right. \\
\left.\mathrm{d}^{-1}\right) \text { at reference } \\
\text { temperature of } \\
10^{\circ} \mathrm{C}\end{array}$ & $\begin{array}{c}\mathrm{Q}_{10} \text { for } \\
\text { background } \\
\text { excretion } \\
\text { rates }\end{array}$ \\
\hline Phytoplankton & 2.0 & 0.34 & $\mathrm{n} / \mathrm{a}$ & $\mathrm{n} / \mathrm{a}$ \\
\hline $\begin{array}{l}\text { Herbivorous } \\
\text { zooplankton }\end{array}$ & 2.2 & 0.34 & 0.01 & 2.4 \\
\hline $\begin{array}{l}\text { Carnivorous } \\
\text { zooplankton }\end{array}$ & 2.2 & 0.34 & 0.005 & 2.4 \\
\hline $\begin{array}{l}\text { Suspension/deposit } \\
\text { feeding benthos }\end{array}$ & 2.2 & 0.34 & 0.01 & 2.4 \\
\hline $\begin{array}{l}\text { Carnivorous/scavenging } \\
\text { benthos }\end{array}$ & 2.2 & 0.34 & 0.0075 & 2.4 \\
\hline Pelagic fish larvae & 2.2 & 0.34 & 0.00005 & 2.4 \\
\hline Pelagic fish adults & 2.2 & 0.275 & 0.001 & 2.4 \\
\hline Demersal fish larvae & 2.2 & 0.34 & 0.00005 & 2.4 \\
\hline Demersal fish adults & 2.2 & 0.25 & 0.001 & 2.4 \\
\hline Birds/mammals & 2.2 & 0.15 & 0.0005 & 2.4 \\
\hline
\end{tabular}




\section{Table S9}

Miscellaneous biological parameters of the model which were fixed and not subject to fitting by the simulated annealing process.

\begin{tabular}{lll}
\hline Parameter & Value & Units \\
\hline $\begin{array}{l}\text { Irradiance at maximum nutrient uptake by } \\
\text { phytoplankton }\end{array}$ & 5 & $\mathrm{E}^{-2} \cdot \mathrm{d}^{-1}$ \\
\hline Pelagic fish: date of onset of spawning & 100 & Day of the year \\
\hline Pelagic fish: duration of spawning & 250 & $\mathrm{~d}$ \\
\hline Pelagic fish: date of onset of recruitment & 1 & Day of the year \\
\hline Pelagic fish: duration of recruitment & 150 & $\mathrm{~d}$ \\
\hline Pelagic fish: annual potential fecundity & 0.25 & $\mathrm{~g} \cdot \mathrm{g}^{-1}$ \\
\hline Demersal fish: date of onset of spawning & 60 & Day of the year \\
\hline Demersal fish: duration of spawning & 90 & $\mathrm{~d}$ \\
\hline Demersal fish: date of onset of recruitment & 200 & Day of the year \\
\hline Demersal fish: duration of recruitment & 150 & $\mathrm{~d}$ \\
\hline Demersal fish: annual potential fecundity & 0.4 & $\mathrm{~g} \cdot \mathrm{g}^{-1}$ \\
\hline $\begin{array}{l}\text { Q10 for mineralization, nitrification and } \\
\text { denitrification (same in all water column layers } \\
\text { and sediment) }\end{array}$ & 2.4 & ${ }^{\circ} \mathrm{C}^{-1}$ \\
\hline
\end{tabular}

\section{Table S10}

Maximum likelihood uptake rate parameters $U_{\max (\text { consumer })}\left(\mathrm{d}^{-1}\right)$ at the reference temperature of $10^{\circ} \mathrm{C}$, and half-saturation constants $h_{\text {(consumer) }}$. Units of the halfsaturation constants are $\mathrm{mMN} . \mathrm{m}^{-3}$, except for the benthos guilds (suspension/deposit, and carnivorous/scavenging benthos) where the units are $\mathrm{mMN} \cdot \mathrm{m}^{-2}$.

\begin{tabular}{llll}
\hline Consumer & $U_{\max (\text { consumer) }}$ & $h_{\text {(consumer) }}$ & $\begin{array}{l}\text { Density } \\
\text { dependent } \\
\text { mortality } \\
\text { coefficient }\end{array}$ \\
\hline Phytoplankton & & $\mathrm{n} / \mathrm{a}$ \\
\hline Herbivorous zooplankton & 1.147 & 16.464 & $\mathrm{n} / \mathrm{a}$ \\
\hline Carnivorous zooplankton & 0.322 & 1.769 & $8.175 \mathrm{E}-04$ \\
\hline $\begin{array}{l}\text { Suspension/deposit feeding } \\
\text { benthos }\end{array}$ & 2.838 & 148.637 & $\mathrm{n} / \mathrm{a}$ \\
\hline Carnivorous/scavening benthos & 0.060 & 6.702 & $6.193 \mathrm{E}-04$ \\
\hline Pelagic fish larvae & 0.534 & 5.801 & $1.990 \mathrm{E}-06$ \\
\hline Pelagic fish adults & 0.058 & 1.176 & $5.260 \mathrm{E}-05$ \\
\hline Demersal fish larvae & 0.209 & 2.818 & $1.140 \mathrm{E}-06$ \\
\hline Demersal fish adults & 0.015 & 0.365 & $4.770 \mathrm{E}-05$ \\
\hline Birds/mammals & 0.137 & 1.433 & $7.384 \mathrm{E}-03$ \\
\hline
\end{tabular}




\section{Table S11}

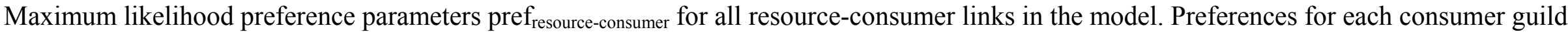
(columns) sum to 1.0

\begin{tabular}{|c|c|c|c|c|c|c|c|c|c|c|c|}
\hline & \multicolumn{11}{|c|}{ Consumers } \\
\hline Resource & ID & 7 & 8 & 9 & 10 & 11 & 12 & 13 & 14 & 15 & $\begin{array}{c}\text { Birds/ } \\
\text { mammals }\end{array}$ \\
\hline Ammonia & 1 & 0.614 & & & & & & & & & \\
\hline Nitrate & 2 & 0.386 & & & & & & & & & \\
\hline Suspended detritus & 3 & & 0.053 & & 0.675 & & & & & & \\
\hline Sediment detritus & 4 & & & & 0.014 & & & & & & \\
\hline Corpses & 5 & & & & & 0.512 & & & & 0.025 & 0.205 \\
\hline Fishery discards & 6 & & & & & & & & & 0.091 & 0.641 \\
\hline Phytoplankton & 7 & & 0.947 & & 0.311 & & & & & & \\
\hline $\begin{array}{l}\text { Herbivorous } \\
\text { zooplankton }\end{array}$ & 8 & & & 0.840 & & & 1.000 & 0.712 & 1.000 & & \\
\hline $\begin{array}{l}\text { Carnivorous } \\
\text { zooplankton }\end{array}$ & 9 & & & & & & & 0.222 & & 0.017 & \\
\hline $\begin{array}{l}\text { Suspension/deposit } \\
\text { feeding benthos }\end{array}$ & 10 & & & & & 0.488 & & & & 0.421 & \\
\hline $\begin{array}{l}\text { Carnivorous/scavenging } \\
\text { benthos }\end{array}$ & 11 & & & & & & & & & 0.032 & \\
\hline Pelagic fish larvae & 12 & & & 0.120 & & & & 0.050 & & 0.119 & \\
\hline Pelagic fish adults & 13 & & & & & & & & & 0.132 & 0.116 \\
\hline Demersal fish larvae & 14 & & & 0.040 & & & & 0.016 & & 0.048 & \\
\hline Demersal fish adults & 15 & & & & & & & & & 0.115 & 0.038 \\
\hline
\end{tabular}


Table S12

Maximum liklelihood values of biogeochemical and fishery discarding parameters.

\begin{tabular}{llll}
\hline Parameter & $\begin{array}{l}\text { Surface } \\
\text { layer }\end{array}$ & Deep layer & $\begin{array}{l}\text { Sediment } \\
\text { layer }\end{array}$ \\
\hline Lysis rate of phytoplankton $\mathrm{d}^{-1}$ & 0.0321 & 0.0501 & $\mathrm{n} / \mathrm{a}$ \\
\hline Sinking rate of detritus $\mathrm{d}^{-1}$ & 0.128 & $\begin{array}{l}0.266 \text { at } \log _{10} \text { vertical } \\
\text { diffusion }(\mathrm{V}(\mathrm{t}))=-6\end{array}$ & $\mathrm{n} / \mathrm{a}$ \\
\cline { 2 - 3 } & & $\begin{array}{l}0.049 \text { at } \log _{10} \text { vertical } \\
\text { diffusion }(\mathrm{V}(\mathrm{t}))=-3.4\end{array}$ & \\
\hline $\begin{array}{l}\text { Coefficient for biomass } \\
\text { dependency of demersal fish } \\
\text { discard rate }\end{array}$ & 0.089 & $\mathrm{n} / \mathrm{a}$ & $\mathrm{n} / \mathrm{a}$ \\
\hline $\begin{array}{l}\text { Conversion rate of fishery } \\
\text { discards to corpses d }\end{array}$ & $\mathrm{n} / \mathrm{a}$ & 0.414 & $\mathrm{n} / \mathrm{a}$ \\
\hline $\begin{array}{l}\text { Conversion rate of seabed } \\
\text { corpses to sediment detritus } \mathrm{d}^{-1}\end{array}$ & $\mathrm{n} / \mathrm{a}$ & $\mathrm{n} / \mathrm{a}$ & 0.0946 \\
\hline $\begin{array}{l}\text { Mineralization rate of detritus at } \\
\text { the reference temperature of } \\
10^{\circ} \mathrm{C}, \mathrm{d}^{-1}\end{array}$ & 0.0082 & 0.0082 & 0.0077 \\
\hline $\begin{array}{l}\text { Nitrification rate of ammonia at } \\
\text { the reference temperature of } \\
10^{\circ} \mathrm{C}, \mathrm{d}^{-1}\end{array}$ & 0.0041 & 0.0427 & 0.0358 \\
\hline $\begin{array}{l}\text { Denitrification rate of nitrate at } \\
\text { the reference temperature of } \\
10^{\circ} \mathrm{C}, \mathrm{d}^{-1}\end{array}$ & 0.0000405 & 0.0000621 & \\
\hline
\end{tabular}




\section{Figure S1}

Stationary time series of dissolved inorganic nutrient state variables in the water column layers and sediment pore water of the model, over the final year of an 80 year run with the maximum likelihood parameter vector and 1970-1999 climatological average physical and chemical driving data. Units for all dissolved nutrient variables: mMN.m ${ }^{-3}$.
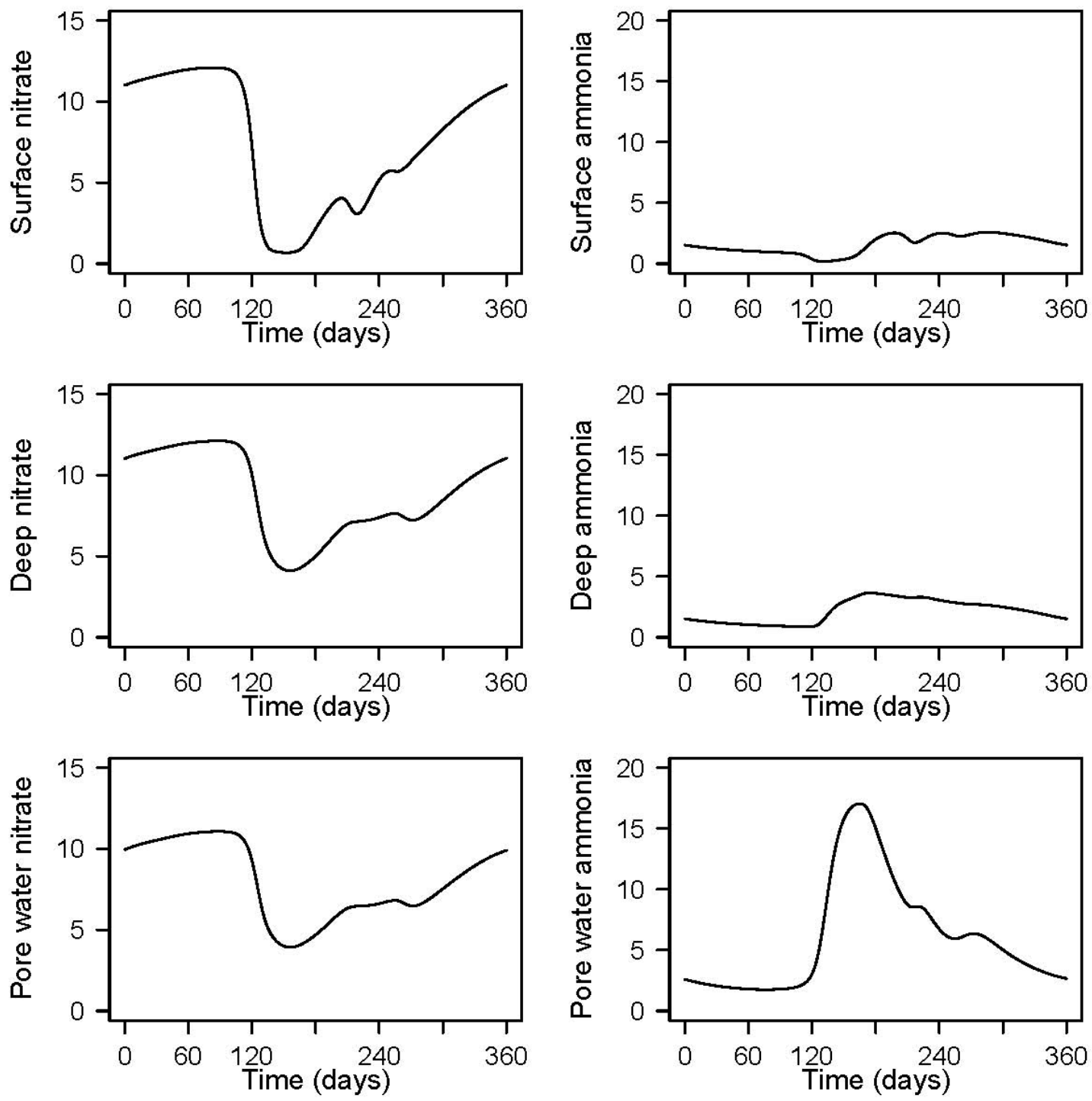


\section{Figure S2}

Stationary time series of dead organic state variables in the model, over the final year of an 80 year run with the maximum likelihood parameter vector and 1970-1999 climatological average physical and chemical driving data. Units for water column detritus variables: $\mathrm{mMN} \cdot \mathrm{m}^{-3}$. Units for fishery discards and corpses: $\mathrm{mMN} \cdot \mathrm{m}^{-2}$.
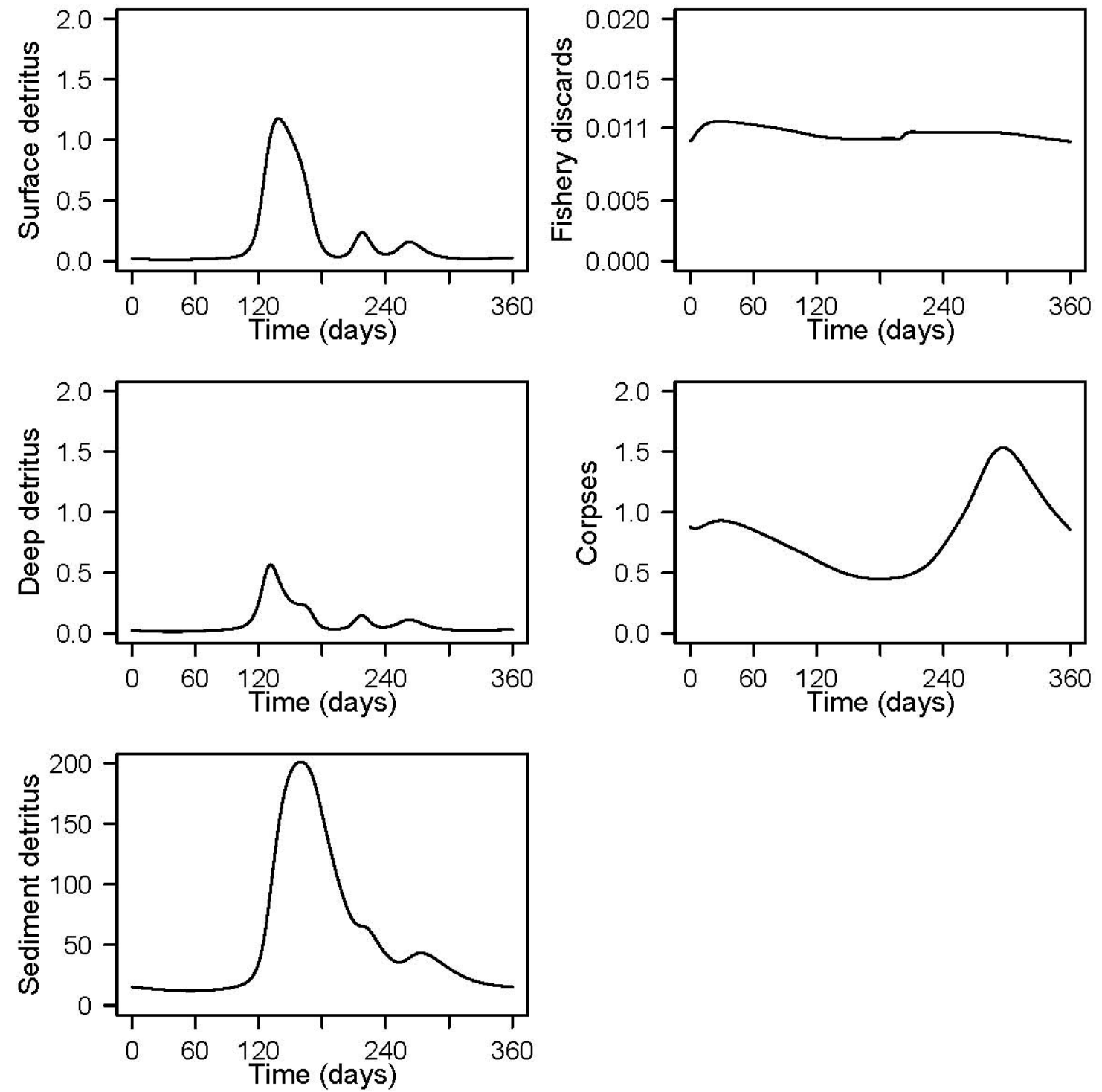


\section{Figure S3}

Stationary time series of phytoplankton and zooplankton state variables in the water column layers of the model, over the final year of an 80 year run with the maximum likelihood parameter vector and 1970-1999 climatological average physical and chemical driving data. Units for all plankton variables: $\mathrm{mMN} . \mathrm{m}^{-3}$.
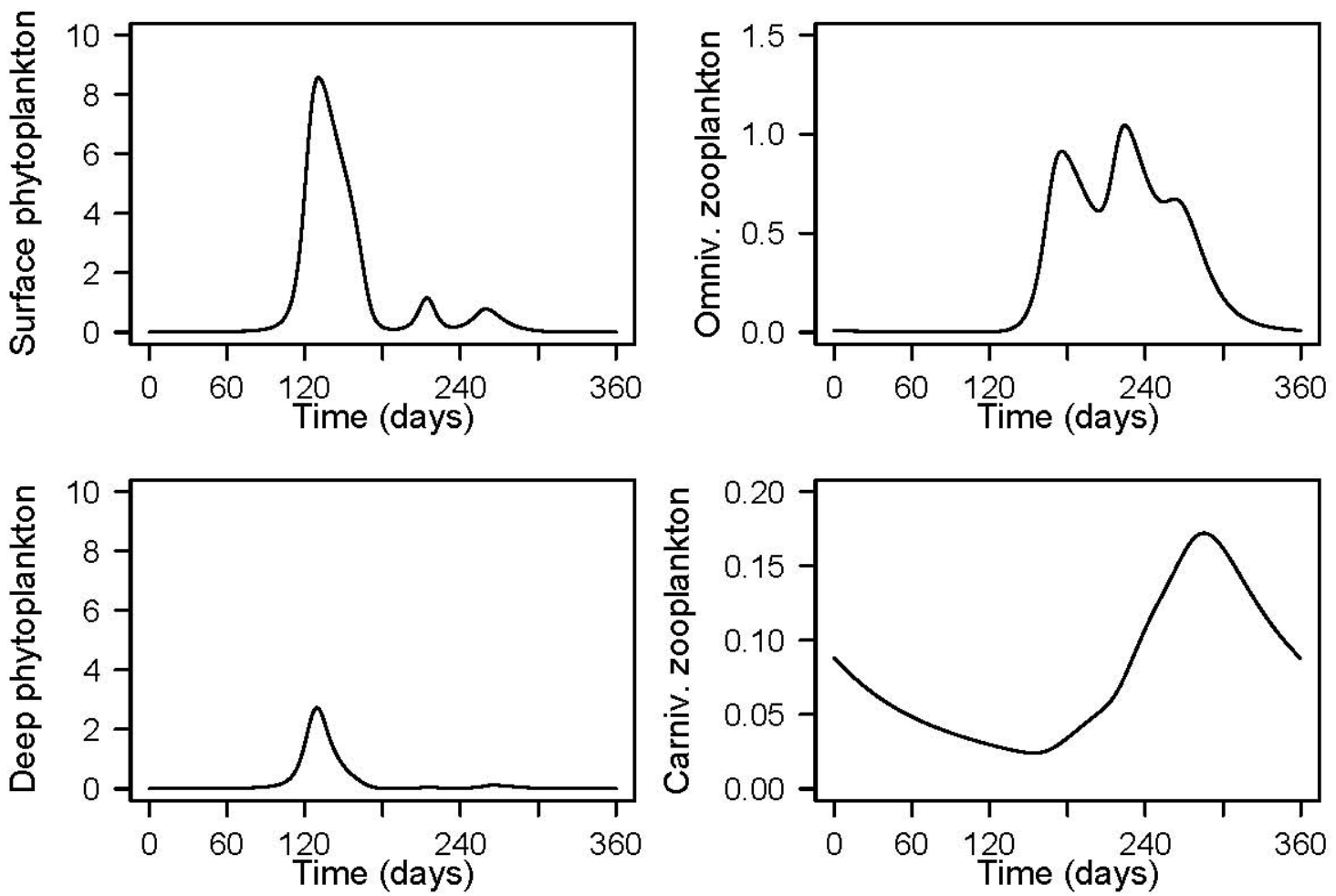


\section{Figure S4}

Stationary time series of larval and adult fish state variables in the model, over the final year of an 80 year run with the maximum likelihood parameter vector and 19701999 climatological average physical and chemical driving data. Units for all fish variables: $\mathrm{mMN} \cdot \mathrm{m}^{-3}$.
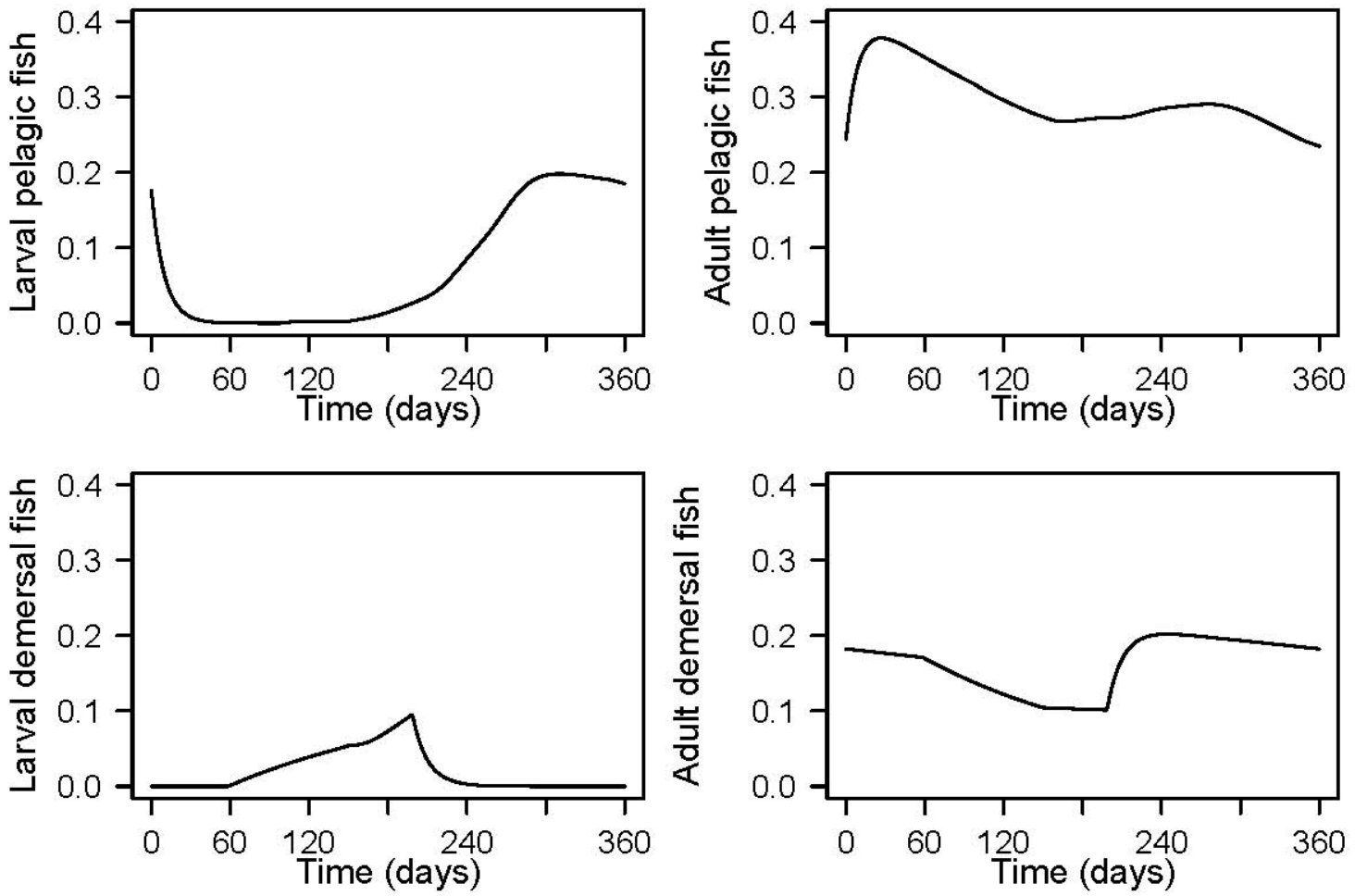


\section{Figure S5}

Stationary time series of filter \& deposit feeding benthos, carnivorous \& scavenge feeding benthos, and bird/mammal state variables in the model, over the final year of an 80 year run with the maximum likelihood parameter vector and 1970-1999 climatological average physical and chemical driving data. Units for benthos and birdm/ammal variables: $\mathrm{mMN} \cdot \mathrm{m}^{-2}$.
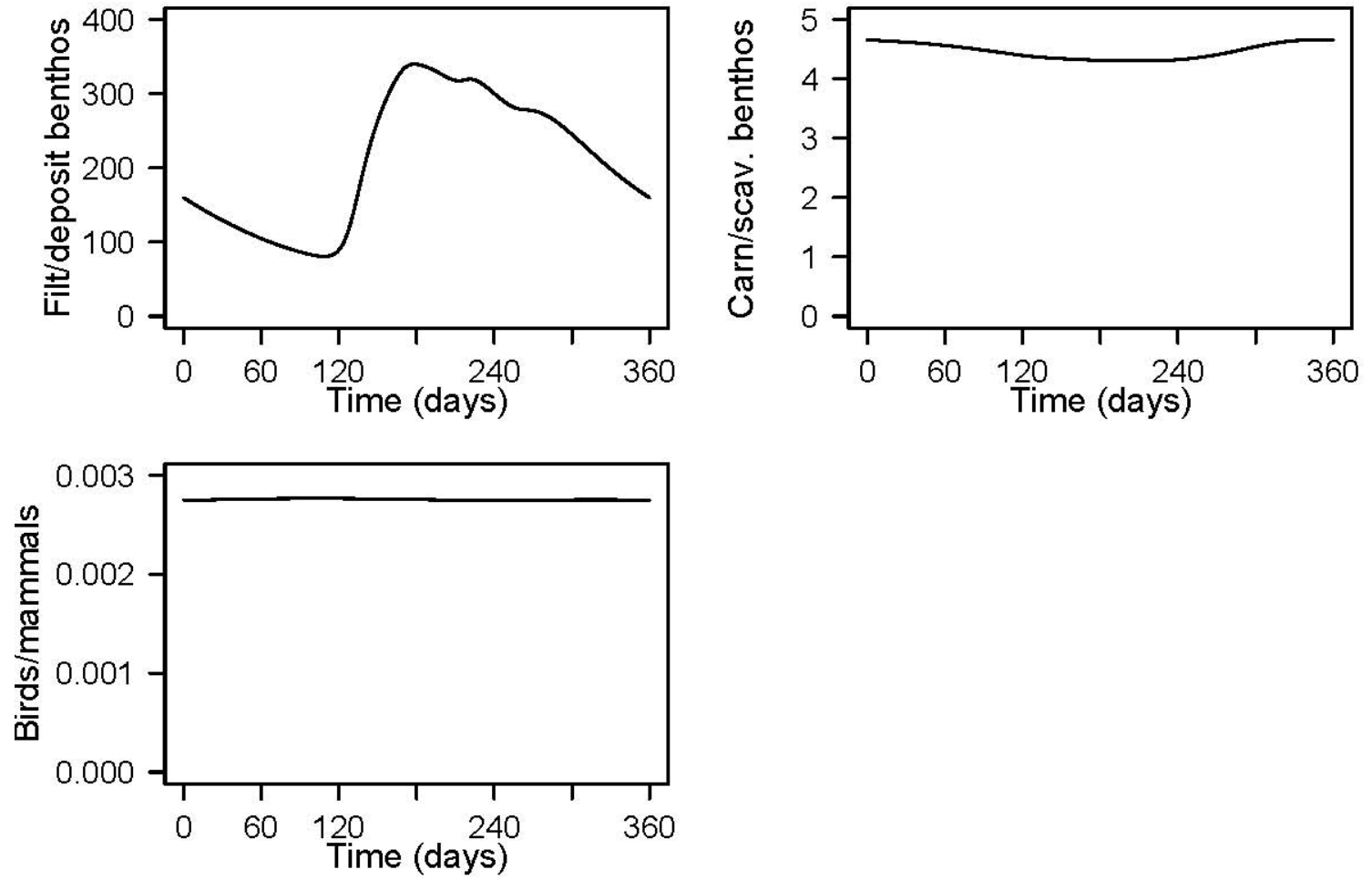